\title{
A Hofmeister effektus vizsgálata szimulációs módszerekkel
}

\author{
Doktori (Ph. D.) értekezés
}

\section{Szerző: Násztor Zoltán}

MTA Szegedi Biológiai kutatóközpont, Biofizikai Intézet

Témavezető: Dr. Bogár Ferenc

MTA-SZTE Biomimetikus Rendszerek Kutatócsoport

Társ-témavezető: Dr. Dér András

MTA Szegedi Biológiai Kutatóközpont, Biofizikai Intézet
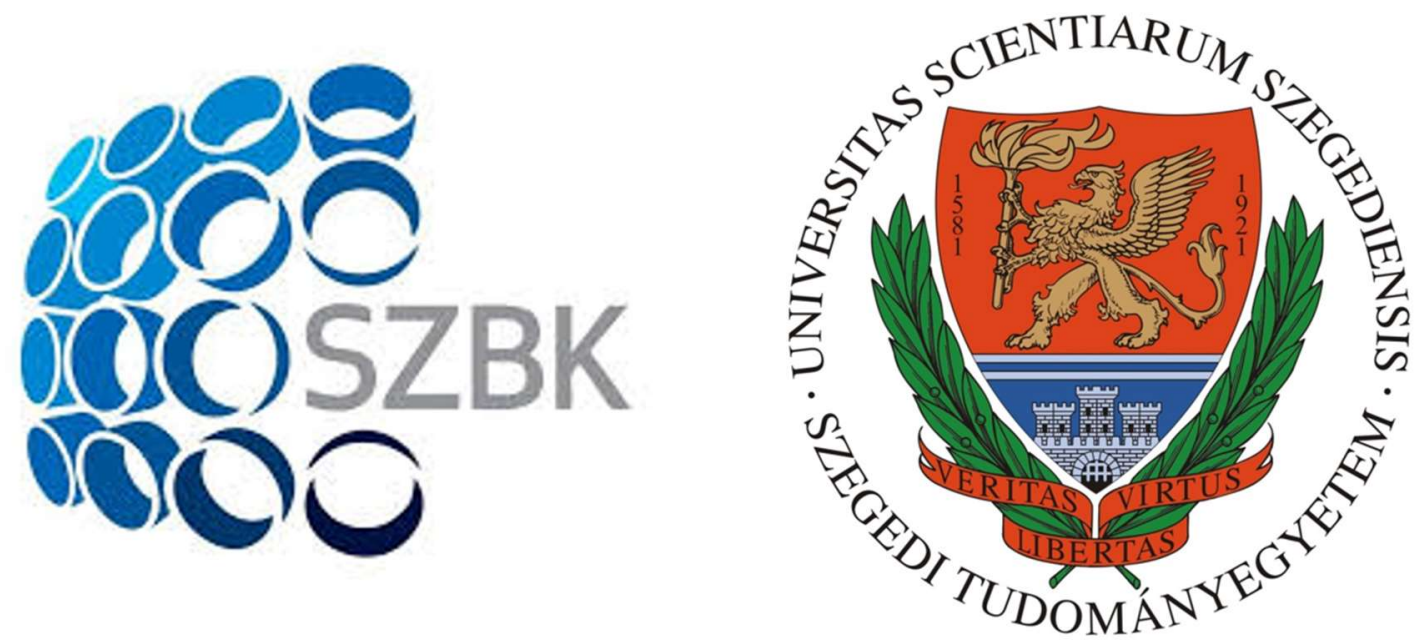

Szegedi Tudományegyetem

Természettudományi és Informatikai Kar

Fizika Doktori Iskola

Szeged 


\section{Tartalomjegyzék}

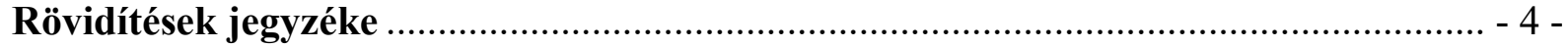

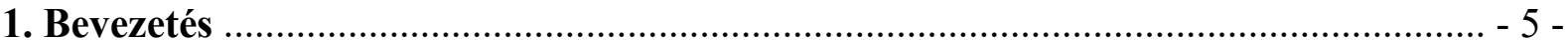

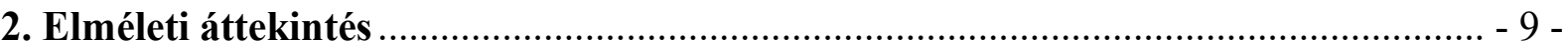

2.1 Határfelületi feszültség koncepció...................................................................... - 9 -

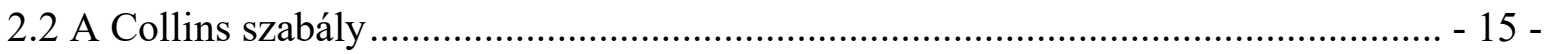

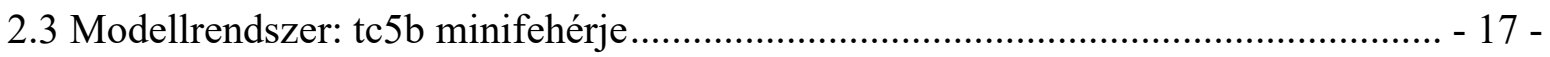

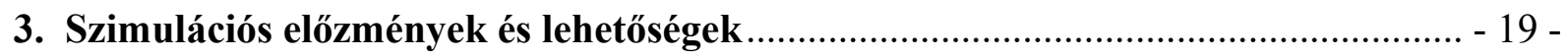

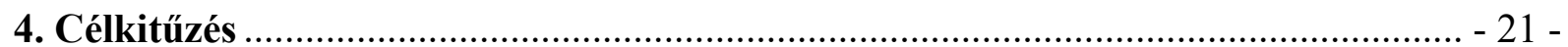

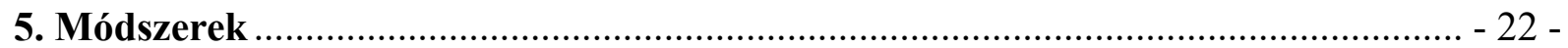

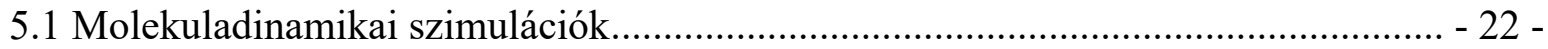

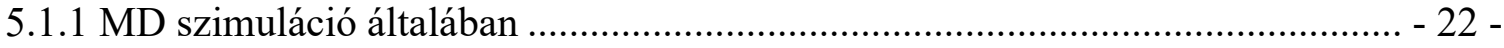

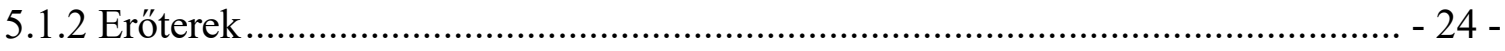

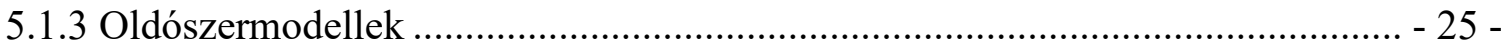

5.1.4 Termodinamikai sokaságok, hőmérséklet- és nyomáscsatolás …….................... - 27 -

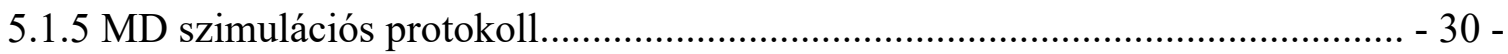

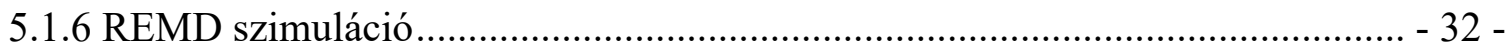

5.2 Az MD paraméterek megválasztása, a modellrendszer............................................ - 34 -

5.3 A molekuladinamikai szimulációk kiértékelése ....................................................... - 35 -

5.3.1 Határfelületi feszültség kiszámítása............................................................... - 35 -

5.3.2 Radiális eloszlás, felületszámolás ................................................................... - 35 -

5.3.3 DDCI görbék, minimális távolság ................................................................. 36 -

5.3.4 Orientációs autokorrelációs függvények....................................................... - 38 -

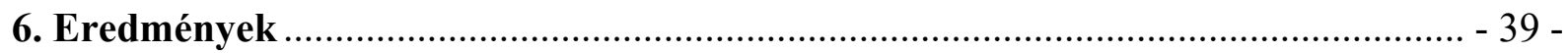

6.1 Oldószer számára hozzáférhető felület............................................................... - 39 -

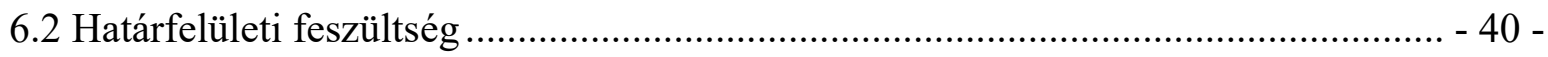

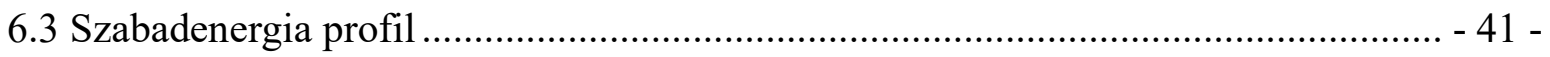


6.4 Fehérje-víz határfelület jellemzői .......................................................................... - 43 -

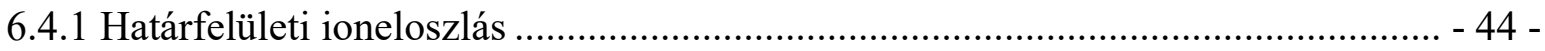

6.4.2 Vízmolekulák orientációs autokorrelációs függvényei.................................... - 47 -

6.4.3 A fehérje és hidratációs környezete közötti kölcsönhatási energia eloszlása ..... - 51 -

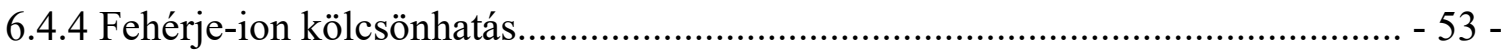

6.4.5 Határfelületi vízmolekulák kölcsönhatási energia szerinti felosztása és a kapcsolódó

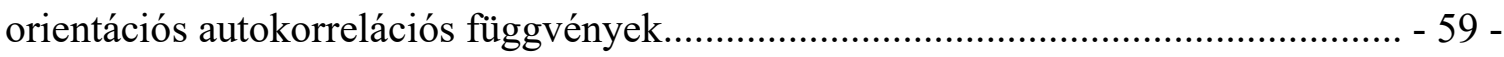

6.4.6 Az ionok és a fehérje felszíni hidratációja ................................................... - 63 -

6.5 Az ionfelhalmozódás lokális jellemzői és kapcsolatuk az aminosav oldalláncok térbeli



6.6 A HE értelmezése mikroszkopikus szinten ........................................................ - 70 -

6.6.1 Kaotróp destabilizáció............................................................................ - 70 -

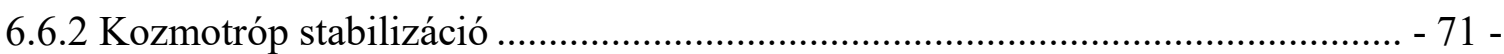

6.7 Helicitás, szerkezeti stabilitás, intramolekuláris kölcsönhatások ............................. - 72 -



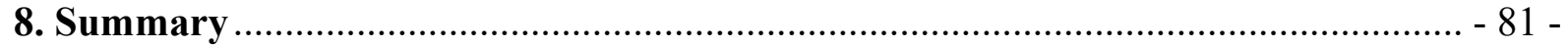

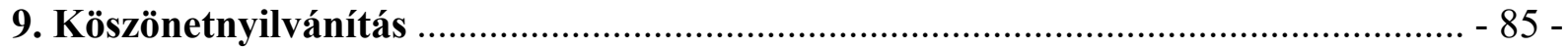

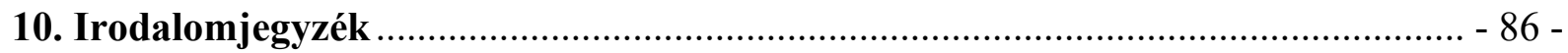

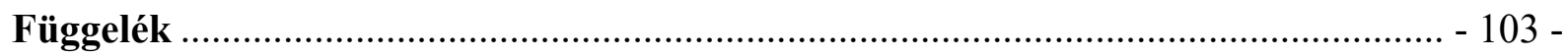




\section{Rövidítések jegyzéke}

HE - Hofmeister-effektus

HS - Hofmeister sor

MD - molekuladinamika

REMD - Replika-csere molekuladinamika (Replica-Exchange Molecular dynamics)

SASA - oldószer számára hozzáférhető felület (Solvent Accessible Surface Area)

DDCI - legközelebbi ionok távolság eloszlása (Distance Distribution of Closest Ions)

CP - közvetlen / kontakt kölcsönhatás / párformálódás (Contact Pair)

SSP - oldószer közvetített kölcsönhatás / párformálódás (Solvent Shared Pair)

2SP - két oldószer molekula által közvetített kölcsönhatás / párformálódás (2 Solvent Pair)

RDF - radiális eloszlás függvény (Radial Distribution Function)

Lys - lizin

Arg - arginin

Pro - prolin

Tyr - tirozin

Trp - triptofán

Gly - glicin

Ser - szerin 


\section{Bevezetés}

Szervetlen sók hozzáadása kémiai, vagy biológiai rendszerekhez számos esetben fizikai-kémiai tulajdonságok sokaságának egyértelmü és reprodukálható megváltozását vonja maga után [14]. Vizes környezetben a sók oldódása révén megjelennek a rendszerben az egyes oldott ionok, módosítva a vízmolekulák és egyéb oldott ágensek közötti kölcsönhatások összetett rendszerét. Ez a hatás élő szervezetekben is megnyilvánul, megváltoztatva a biomolekulák közötti kölcsönhatásokat, a fehérjék oldhatóságát és aggregációs tulajdonságait, valamint térszerkezetüket és annak stabilitását is [5].

Az ionok - biológiai rendszerekre gyakorolt hatásuk szerinti - osztályozását először a fehérjék oldódási tulajdonságait tanulmányozva végezték el. Mint az régóta ismert, a semleges sók közepes- és nagyobb koncentrációban (megközelítőleg $100 \mathrm{mM}$ koncentráció felett) figyelemre méltó hatással vannak a fehérjék oldhatóságára. Az oldott ionok hatására vagy fokozódik a fehérjék kiválása az oldatból - ezt nevezzük „,kisózásnak” -, vagy ezzel ellentétesen, növekszik az oldhatóság, azaz „besózás” történik. Ezt a jelenséget Hofmeister-effektusnak (HE) nevezzük Franz Hofmesiter után [6], aki a fehérjék oldhatóságának kationok és anionok hatására bekövetkező változását tanulmányozta. A megfigyelések szerint az anionok hatása számottevőbb, mint a kationoké. Ezen felül, 1888-ban Hofmeister empirikus módon sorba rendezte az ionokat, aszerint, hogy milyen mértékben módosítják a globuláris fehérjék oldhatóságát (1. ábra).

\section{$\mathrm{SO}_{4}^{-2}>\mathrm{F}^{-}>\mathrm{CH}_{4} \mathrm{COO}^{-}>\mathrm{Cl}^{-}>\mathrm{Br}^{-}>\mathrm{I}^{-}>\mathrm{ClO}_{4}^{-}, \mathrm{SCN}^{-}$}

1. ábra Néhány kiválasztott anion Hofmeister sora.

Az ionok ilyen (1. ábra szerinti) rendezését Hofmesiter-sornak nevezzük. Az ennek közepén található $\mathrm{Cl}^{-}$ion közel semleges hatású („Hofmeister-semleges” ion), tőle balra találhatóak az aggregációt fokozó, míg jobbra az azt csökkentő anionok (együtt: „Hofmeister-aktív” ionok).

A fehérjék egy komplex, vízmolekulákat is tartalmazó rendszerben fejtik ki biológiai hatásukat. Ez a közeg az optimális müködésükhöz szükséges [7], és egyszerre nyújt stabilitást és flexibilitást $[8,9]$ is. Szoros kapcsolat áll fent a fehérjék biológiai aktivitása és szerkezetük között, továbbá gyakran reverzibilis szerkezeti változások lépnek fel a biológiai hatás kifejtése során. A fehérjék szerkezetének jellemzésére négy jól elkülöníthető szintet különböztetünk meg. Az elsődleges szerkezeten a fehérjéket alkotó, egymáshoz peptid kötésekkel kapcsolódó aminosavak sorrendjét, vagy szekvenciáját értjük. A szekvenciában szereplő első aminosav az úgynevezett N-terminálson található, amit a szabad amin (-NH2) csoport után nevezünk így; ehhez hasonlóan az utolsó aminosav a C-terminálison található (a karboxil csoport (-COOH) után elnevezve). A leggyakrabban előforduló másodlagos szerkezeti elemek közé tartozik az $\alpha$ és a 310 -hélix, továbbá a $\beta$-redő és a $\beta$-kanyar szerkezetek. Minden egyes ilyen térszerkezeti elem aminosavak egymáshoz képest rögzített térbeli elhelyezkedését jelenti, melyek például a fölánc meghatározott diéderes szögpárjai, vagy H-híd kötések segítségével azonosíthatóak. Harmadlagos szerkezet alatt a fehérje teljes térbeli szerkezetét értjük, amelyben a különböző 
másodlagos szerkezeti elemekkel rendelkező szegmensek egymáshoz képest térben rendeződnek. Ha egy több fehérje-alegységből álló komplex együttes térbeli szerkezetét vizsgáljuk, akkor beszélhetünk negyedleges szerkezetröl. Emellett van számos olyan fehérje, amelyekre nem-, vagy csak részben jellemző a stabil másodlagos és harmadlagos szerkezet, ezek az IDP-k (Intrisically Disordered Proteins) [10]. Megkülönböztethető még a globuláris fehérjék népes csoportja, melyek ,gömbszerü" harmadlagos szerkezettel rendelkeznek, általában víz-oldékonyak és a hidrofób aminosavak jelentős része nem kitett az oldószer számára, hanem egy „hidrofób magban” található. Ebbe a csoportba tartozik például a hemoglobin, az albuminok, több globulin és számos, alapvető fontosságú metabolikus folyamatban résztvevő enzim.

A fehérjék esetében kísérleti módszerekkel is demonstrálták, hogy jelentős konformációs változásaik az első oldódási burkuknak és az azt körülvevő tömbfázisnak vannak alávetve [11, 12]. Ennek következtében a HE-t kapcsolatba hozták az anionok vízszerkezetre gyakorolt hatásával. A vízmolekulák között kialakuló H-híd kötések erőssége számos tényezőtől függ, érzékeny például a hőmérséklet változására, amely a vízmolekulák hőmozgására is hatással van. Mindemellett azonban az oldathoz hozzáadott ionok is gyengíthetik, vagy erősíthetik a vízmolekulák közötti kölcsönhatást, továbbá átalakíthatják a H-híd kötések rendszerét, a vízmolekulák térbeli orientálása által. Azokat az ionokat, amelyek a H-híd kötéseket erősítik, kozmotrópoknak (,szerkezetépítők”), míg amelyek gyengítik, kaotrópoknak (,szerkezetrombolók”) nevezzük [3]. Összekapcsolva az ionoknak önmagában a vízszerkezetre illetve a globuláris fehérjékre gyakorolt hatását, megállapítható, hogy a kozmotróp ionok növelik az aggregációt, a kaotrópok pedig csökkentik.

Későbbi vizsgálatok kimutatták, hogy az oldathoz hozzáadott ionok, és az általuk létrehozott vízszerkezetet és H-híd kötéserősséget érintő - változások nem csak a fehérjék oldhatósági tulajdonságaira vannak hatással. Az oldódási környezet ilyen jellegü megváltozása jelentősen befolyásolja a fehérjék térszerkezetét és annak stabilitását, továbbá mindezek következtében gyakran biológiai hatásukat is. A fehérjék első és második oldódási burkában található „fehérjeközeli" vízmolekulák szerepe nagyobb mértékü az egyes konformációk kialakításában és fenntartásában. A kozmotróp ionok általában növelik az enzimek aktivitását és a szerkezeti stabilitását, a kaotróp ionok hatása pedig ezzel ellentétes [2,3], viszont némely fehérje esetében mindez éppen fordítva történik, vagy más, kivételes módon reagálnak az oldott ionok jelenlétére.

Az ionok, a vízmolekulák és a gyakran változó felszínnel rendelkező egyéb oldott molekulák (pl. fehérjék) egy komplex kölcsönhatási hálózatot hoznak létre egymás között. Ahogy azt a fentiekben láthattuk, a fehérjék térszerkezetét és annak stabilitását döntően az oldódási környezetük határozza meg [8], mindemellett a fehérje - ennek a környezetnek kitett - felületi csoportjainak fluktuációi is fontos szerepet játszanak, ahogy azt nemrégiben femtoszekundumos spektroszkópiai vizsgálatok is kimutatták [13]. Ugyanakkor, megfordítva a gondolatmenetet, a határfelületen található víz szerkezetét és kölcsönhatását a fehérjékkel javarészt a fehérjefelszín tulajdonságai (geometria, töltés) határozzák meg [8]. A lokális geometria és a felületi töltéseloszlás meglehetősen sokféle mintázatot eredményezhet, ami viszont más-más fehérje-víz (és fehérje-ion, víz-ion) kölcsönhatást von maga után. A töltött és 
poláros kölcsönhatási helyek donorként, vagy akceptorként részt vehetnek különböző erősségü H-híd kötések kialakításában. A hidrofób felületelemeknél ez a tulajdonság hiányzik, így a vízmolekulák ilyen környezetben jellemzően egymás között alakítanak ki H-híd kötéseket. Ez egy speciális vízszerkezet kialakítását jelenti, ami valamivel „merevebb”, mint a tömbfázisbeli szerkezet, bár nem olyan mértékben, mint azt korábban Frank és mtsi. gondolták [14] a „jéghegy” modellben. Nemcsak a töltés és a hidrofóbicitás a kizárólagos befolyásoló tényezők egy felület hidratációját tekintve, hanem a felület geometriája is hatást gyakorol a kialakuló vízszerkezetre. Egy kicsiny, konvex, hidrofób felület körül ún. „Clathrate” - kristályszerü folyadékszerkezet - formálódik [15], emellett konkáv felületelemek is rendelkezhetnek specifikus víz-megkötési tulajdonsággal (pl. kötőzsebek) [16]. Összességében egy fehérjefelszín önmagában változatos oldódási mintázatokat mutat általában, aminek hatása van többek között a fehérje és a környezete közötti kölcsönhatási energiára, ill. annak eloszlására, továbbá egyéb entalpikus és entrópikus jellemzőkre.

Az eddig említett oldódási sajátságokat természetesen jelentősen megváltoztatja a Hofmeisteraktív ionok jelenléte. Mind a kozmotróp, mind a kaotróp ionok korábban említett oldódási tulajdonságai és a vízszerkezetre gyakorolt hatásuk mellett megvannak a saját, fehérjespecifikus felhalmozódási, eloszlási jellemzői. Az oldott ionok nemcsak egymással és a vízmolekulákkal hatnak kölcsön, hanem különböző típusú kölcsönhatásokba léphetnek a fehérjékkel is. Az ionokhoz köthető hatások gyakran meghatározó szerepet játszanak fizikai, kémiai és biológiai rendszerekben fellépő jelenségekben. Ilyenek például a kolloid szuszpenziók stabilitása, enzimek aktivitása, vagy ligandumok receptorhoz kötődése [2, 3, 17]. Vagyis a HE nem korlátozódik kizárólagosan fehérjékre, megjelenik poliszacharidok, nukleinsavak és foszfolipidek esetében is. Nemrégiben Lo Nostro és munkatársai [17] végeztek szerteágazó vizsgálatokat a HE biológiai hatásának tekintetében, illetve felhívták a figyelmet egyéb a HE-hoz köthető megoldatlan problémákra [18]. A HE jelentősége és az intenzív kutatási munka ellenére, illetve az említett kivételek miatt, az effektus mögött rejlő atomi szintü folyamatok értelmezése, azaz a teljeskörü, koherens elméleti leírás még több, mint 100 év távlatából sem történt meg.

A HE sokrétű előfordulása és összetettsége ellenére, fenomenologikus szinten is történtek kísérletek az effektus leírására és néhány egyszerű koncepció meglepő módon kifejezetten jól teljesített [19-21]. Ezek a leírások alapvetően a víz-fehérje határfelület tulajdonságaival és ahhoz kapcsolódó mennyiségekkel dolgoztak, bevezetve a határfelületen fellépö felületi feszültséget. Alkalmazva ezeket a módszereket sikeresen értelmeztek egy sor HE-hez köthető jelenséget „globális” (makromolekuláris) szinten. Továbbá, szimulációs eredmények támogatásával sikerült kidolgozni mikroszkopikus szinten is koncepciókat. A víz-molekula határfelületen értelmezett felületi feszültség (a szabadenergia oldószer számára hozzáférhető felület -SASA - szerinti deriváltja) sikeres alkalmazása azt is jelenti, hogy az egyik legjelentősebb tényező a HE-t tekintve a víz-fehérje határfelület ionok által kiváltott szabadenergia változása.

Nemrégiben Dér és mtsi. bemutatták, hogy egy egységes, fenomenologikus formalizmus, ami a határfelületi feszültségen alapszik, alkalmazható számos HE-hoz köthető jelenség kvalitatív leírására [20]. A legfontosabb megállapításuk az volt, hogy a kozmotróp és kaotróp sók 
növelhetik, illetve csökkenthetik a határfelületen fellépő felületi feszültséget a tiszta vizes esethez képest, ami megjelenik az adott rendszer szabadenergia-változásban is. Továbbá, Dér és Neagu azt is javasolták [21], hogy a HE mikroszkopikus szintü értelmezéséhez a határfelületi feszültség és a fehérjék konformációs fluktuációi közötti kapcsolatot érdemes vizsgálni. Az elmélet sikerességének ellenére közvetlen bizonyíték a HE-hoz köthető, a sók által kiváltott határfelületi feszültség változásra nincs. Ez az egyik kérdés, amivel foglalkozni fogunk, MD módszerek felhasználásával. Megvizsgáljuk a Hofmeister-aktív sók által kiváltott konformációs fluktuációkat, és a kapcsolódó SASA változásokat. A SASA adatokat felhasználva származtatjuk a felületi feszültség változásokat.

A mikroszkopikus folyamatok leírása érdekében részletesen megvizsgáljuk a határfelületi régió tulajdonságait is. Meghatározzuk az ionok eloszlását, a határfelületi vízmolekulák tulajdonságait. Az ionok határfelületi eloszlása mellett a fehérje-ion kölcsönhatások feltérképezése fontos segédeszköz a HE atomi szintű értelmezésében, melynek során Collins és mtsi. munkáit is felhasználtuk [22]. Az alapvető elgondolás az anion-kation párformálódási tulajdonságok Hofmeister-aktivitással történő összekapcsolása volt, alkáli-halogének esetében. A „összeillő vízoldékonyság törvénye” szerint hasonló oldhatóságú kozmotróp-kozmotróp, ill. kaotróp-kaotróp párok lehetnek stabilak. Ez a koncepció fehérjefelszínen értelmezve hasznos eszköz a fehérje-ion kölcsönhatás értelmezésére. Nemrégiben, mind kísérleti, mind szimulációs munkák kimutatták, hogy fehérjék és kaotróp ionok között létrejön közvetlen kölcsönhatás, és a kaotróp anionok felhalmozódnak a fehérje-víz határfelületen $[2,20]$. A határfelületi régió részletes vizsgálata feltétlenül szükséges annak érdekében, hogy jobban megérthessük az ionok által kiváltott felületi feszültség változást és a kapcsolódó mechanizmusokat.

Szimulációs módszerek segítségével kimutattak az ionok hatására bekövetkező felületi feszültség változásokat vákuum-víz határfelületen [23], melyek jól megfeleltek kísérleti eredményeknek. Ezen felül, alkáli-halogenid sók által kiváltott hatásokat vizsgáltak meg töltött alanin-alapú fehérjéken [24-26], továbbá arginin és alanin aminosavakból felépülő modellrendszerek másodlagos szerkezeti elemeinek perklorát ionok által kiváltott változásait is vizsgálták [27]. Ezek a számolások demonstrálták a klasszikus, nem polarizálható erőterek és explicit vizes MD módszerek alkalmazhatóságát az ionok által kiváltott hatások tanulmányozására. Felhasználva ezeket az előzményeket, a MD számolásainkat egy sokkal „fehérjeszerübb” modellrendszerre végeztük el, a tc5b minifehérjére. Összehasonlítás és referenciaként történő felhasználás céljából a választott modellrendszerünket illetően számos szimulációs és kísérleti adat [28-36] rendelkezésre áll. 


\section{Elméleti áttekintés}

\subsection{Határfelületi feszültség koncepció}

A fehérjék oldódását vizsgálva néhány száz millimólos koncentrációban egy komplex oldódási környezetben, és figyelmen kívül hagyva a kivételeket, a HE fenomenologikus képe igen egyszerü. A kozmotrópnak nevezett sók csökkentik a fehérjék oldhatóságát (kisózódás), míg a kaotrópok növelik azt (besózódás) [2, 3]. A Setschenow-törvény egy egyszerü, kvantitatív összefüggést szolgáltat a magas koncentrációjú határesetre (számos kísérleti igazolás mellett):

$$
\log S_{0}{ }_{S}=K_{S} \cdot C_{S}
$$

Ahol az $S_{0}$ és $S$ a fehérje oldhatóságát jelenti rendre a tiszta vizes esetben és $C_{S}$ sókoncentráció esetében. A $K_{S}$ Setschenow-konstans értéke pozitív kozmotróp sókra és negatív kaotróp sók esetében [37]. Ennek az összefüggésnek az egyszerüsége számos, a $K_{S}$-hez kapcsolható fizikai mennyiség bevezetésére irányuló próbálkozást motivált. Az egyik legnépszerübb megközelítés az ún. kavitációs-modell volt, melyet Melander és Horváth [38] javasoltak eredetileg, majd számos finomítás történt a modellen [5, 39-41]. Ezek az úttörő munkák azzal az alapötlettel dolgoztak, hogy a HE által bekövetkező, az ionok által előidézett vízszerkezet-változásokat kapcsolatba hozták a levegő-víz határfelület felületi feszültség változásával, mely mennyiségről ismert volt, hogy szintén függ a só koncentrációtól a HS-nak megfelelően. Ezt írja le a Heydweiller-egyenlet [42]:

$$
\Delta \gamma_{L}=K_{H} \cdot C
$$

Ahol az „L” index a levegő-víz határfelületre utal a felületi feszültség változás esetében, a $K_{H}$ pedig a Heydweiller konstans. melynek értéke kisebb kaotróp sókra, mint kozmotrópokra [3]. Feltételezésük szerint az oldódás során a fehérje szabadenergiája úgy adható meg, mint egy a fehérjének megfelelő alakú és méretű kavitáció létrehozásához szükséges mennyiség. Miután első lépésként ez a kavitáció létrejött, a fehérje levegőből, vagy vákuumból behelyezhető a számára létrehozott helyre, innen eredeztetve a levegö-víz határfelületi feszültséget. Kisebb méretü molekulák, például, mint a benzol esetében, amit gyakorlatilag minden Hofmeister só kisóz, az elmélet jól működött [5, 43]. Azonban fehérjékre nem volt alkalmazható, mivel a HEnak csak az egyik felét, a kozmotróp kisózást tudta kezelni. Ez annak a következménye, hogy az összes vizsgált só növelte a levegő víz határfelületi feszültséget, így mind a kaotróp, mind a kozmotróp sók pozitív határfelületi feszültség változást okoztak [3]. Másként fogalmazva a $K_{H}$ konstans elöjele mindig pozitív, így nem tudta szolgáltatni a Setschenow konstans esetében fellépő előjelváltást, amely az oldódási környezet kozmotróp/kaotróp jellegének megváltozása következtében figyelhető meg. Olyan fizikai jelentéssel bíró mennyiség bevezetése, amely önmagában alkalmas a HE minden egyes megjelenési formájának leírására nem volt sikeres az utóbbi időkig. 
Nemrégiben Dér és munkatársainak [20] sikerült olyan egységes elméletet kidolgozniuk, ami a molekula-víz határfelületi feszültség sófüggésén alapul, és fenomenológiai leírást ad a HE-k eddig ismert megjelenési formáira. A koncepció kiindulási pontja, hogy a kavitációs modell víz-levegő határfelületén fellépő felületi feszültség helyett a Setschenow törvényt közvetlenül a fehérje-víz határfelületen kell értelmezni. A HE értelmezését a teljes szabadenergia-változás SASA-val arányos tagjára tekintettel közelítjük meg. Általánosságban egy fehérjét érintő minden releváns folyamat (oldódás, aggregáció, konformációs változás) esetén feltételezzük, hogy a szabadenergia-változás két tagra bontható a következő módon:

$$
\Delta G_{\text {teljes }}=\Delta G_{\text {fehérje belső }}+\Delta G_{\text {határfelületi }}
$$

A szabadenergia-változás határfelületi tagjának meghatározásához szükséges az oldószer számára hozzáférhető felület (SASA) bevezetése, ami alatt a biomolekulák felszínének azon részét értjük, ami hozzáférhető az oldószermolekulák számára. A molekuláris felszín fogálmát először Lee és Richards vezették be [44]. Ezt a mennyiséget általában angström-, vagy nanométer-négyzetben adják meg, és a számolása főként olyan algoritmusok segítségével történik, amelyek során a vizsgált molekula atomjainak van der Waals sugara által meghatározott felszínén egy vízmolekula, vagy egy adott sugarú gömb segítségével („körbe görgetésével”) térképezzük fel a felszínt. Az első sikeresen müködő algoritmust Shrake és Rupley dolgozták ki, és segítségével meghatározták az inzulin és a lizozim felszínét [45].

A fehérjeoldódás valószínüleg legegyszerübb modellje szerint (kavitációs / cseppmodell), amely szerint egy feloldott fehérje szabadenergiája lineárisan függ a SASA nagyságától, azaz:

$$
G_{\text {határfelületi }}=G_{0}+\gamma \cdot A
$$

Ahol $G_{0}$ egy konstans érték, $\gamma$ az effektív felületi feszültség, A pedig a SASA nagysága.

Annak érdekében, hogy a felületi feszültség összeköthető legyen az oldhatósággal egy egyensúlyt feltételeztek egy szilárd- (fehérje aggregátum) és egy oldott (egyes fehérjék) állapot között, tiszta vizes környezetben. Ekkor a kémiai potenciálok között fennálló összefüggés:

$$
\mu_{S}=\mu_{o}+R \cdot T \cdot \ln \left(x_{0}\right)
$$

Ahol a $\mu_{S}$ és a $\mu_{o}$ rendre a szilárd és az oldott állapot kémiai potenciálja, az $R \cdot T \cdot \ln \left(x_{0}\right)$ a „keverési tag” [46], ahol az $x_{0}$ a móltörtje az oldott és a nem oldott fehérjéknek (a 0 -s index jelen esetben a tiszta vizes esetet jelöli) [47]. Ugyanez az összefüggés más oldódási környezetben (pl. Hofmeister-aktív sók jelenlétében):

$$
\mu_{S}=\mu+R \cdot T \cdot \ln (x)
$$

Ahol $\mu$ és $x$ az adott oldatra jellemző mennyiségeket jelölik. 
Feltételezve, hogy $\mu$ és $\mu_{o}$ csak a felületi feszültségekhez tartozó tagokban térnek el, a (5) és (6) egyenletekből következik:

$$
\left(\gamma-\gamma_{0}\right) \cdot A_{f v}=R \cdot T \cdot \ln \left(x_{0} / x\right)
$$

Ahol $\gamma$ és $\gamma_{0}$ a fehérje-víz határfelületi feszültség rendre a (Hofmeister-) sókat tartalmazó- és a tiszta vizes oldatban, az $A_{f v}$ mennyiség pedig a fehérje-víz határfelület moláris értéke ( $S A S A *$ $N_{A}$, ahol $N_{A}$ az Avogadro szám és SASA a molekuláris oldószer számára hozzáférhető felület).

Ugyanakkor Dér és munkatársai kimutatták, hogy az $x_{0} / x$ hányados megfelelően közelíthető az $S_{0} / S$ hányadossal [20], így az (7) és (1) egyenletek felhasználásával származtatható a következö összefüggés:

$$
\Delta \gamma=\gamma-\gamma_{0}=2,303 \cdot R \cdot T \cdot \frac{K_{s} \cdot c}{A_{f v}}
$$

Mely összefüggés lineárisan függ a só (általánosabban bármilyen hozzáoldott anyag) koncentrációjától, és az arányossági tényező a Setschenow-konstans $\left(K_{S}\right)$, ami egy pozitív számmal van megszorozva. Ennek következtében $\Delta \gamma$ előjele követi $K_{S}$ előjelét, azaz pozitív lehet kozmotróp- és negatív kaotróp sók jelenlétében. A (8) egyenlet közvetlen kapcsolatot teremt a Setschenow-konstans és egy fizikai mennyiség között. A felületi feszültség segítségével a HE oldhatóságra vonatkozó értelmezése így egy nagyon kifejező értelmezést nyer, amely a fehérje konformációkra vonatkozó csepp-modellt foglalja magába, egyszerre kezelve a kozmotróp és kaotróp effektusokat.

Ugyanakkor elgondolkodtató, hogy indokolt lehet-e egy makroszkopikus mennyiség, mint például a felületi feszültség mikroszkopikus szinten történő alkalmazása. Tulajdonképpen ez egy régóta tartó vita, föleg a hidrofób kölcsönhatások termodinamikai leírásával kapcsolatban [48]. Az eddigi vizsgálatok kimutatták, hogy a mikroszkopikus és makroszkopikus felszínek kvalitatívan hasonlóan viselkednek [5, 49], természetesen figyelembe kell venni a felületi geometria által diktált korrekciókat (pl. nagyobb görbület), továbbá a fehérjefelszín inhomogenitásait és ,szemcsésségét”[48, 49]. Habár mindezek jelentős korrekciós faktorokat jelenthetnek, ésszerü feltételezni, hogy ez a koncepció hasznos eszközként szolgálhat a molekuláris felszínen végbemenő folyamatok értelmezésére. A (8) egyenlet úgy is értelmezhető, hogy a Hofmeister-aktív sók megváltoztatják a fehérjefelszín hidrofób/hidrofil tulajdonságait, nevezetesen a kozmotróp sók hidrofóbabbá, míg a kaotróp sók hidrofilebbé teszik azokat [20].

A $\Delta \gamma$ mennyiség mérésére nincs közvetlen mérési eljárás. Ugyanakkor a fehérje-víz határfelület esetében, ha ismert, hogy milyen tényezőktől függ az értéke, akkor közvetett kísérleti bizonyítékok alátámaszthatják a koncepciót. Az alábbi három faktortól mindenképpen függenie kell $\Delta \gamma$ értékének [20] (mivel, alapvetően a kohéziós és adhéziós erők határozzák meg, amely az egyes fázisok között, ill. fázisokban lépnek fel): 
1) a felszínen lévő aminosavak tulajdonságai

2) a vízmolekulák közötti H-híd kötések erőssége

3) a Hofmeister-aktív sók felszín-közeli és tömbfázisban mért koncentrációi közötti különbség

Az 1) pontból következik, hogy $\Delta \gamma$ függ a fehérje megválasztásától. Valójában, az (1) és (8) egyenletekben szereplő $K_{S}$ a hozzáoldott sók mellett a választott fehérjétől is függ [2]. A Hofmeister-aktív sók hozzáadása a rendszerhez nyilvánvalóan befolyásolják a 2) és 3) pontokat. A 2) és 3) pontok szempontjából számos releváns kísérleti adat elérhető az irodalomban [2, 50, 51], melyek kapcsolatba hozhatók a fehérje-víz határfelületi feszültséggel.

A fehérje-víz határfelületi feszültség koncepció tekintetében a fehérjék kicsapódásavisszaoldódása volt a kiinduló pont, másfelől viszont hasznos eszköznek bizonyulhat a HE által kiváltott fehérjekonformációt/-müködést érintő változások jellemzésében. Ugyanis a fehérjék jelentős szerkezeti változásait a SASA számottevő változásai kísérik, például amikor egy „nyitott” és egy „zárt” konformáció között váltakozik egy fehérje állapota. A fenti jelöléseket alkalmazva, a szabadenergia-változás felületi feszültséget érintő komponense a következő alakban írható:

$$
\Delta G_{\text {határfelületi }} \sim \gamma_{f v} \cdot \Delta A_{f v}
$$

Hofmeister-aktív sók jelenlétében viszont $\gamma_{f v}^{\prime}=\gamma_{f v}+\Delta \gamma_{f v}((8)$ egyenlet), így a sófüggő járuléka a határfelületi szabadenergia-változásnak:

$$
\Delta \Delta G_{\text {határfelületi }}=\Delta \gamma_{f v} \cdot \Delta A_{f v}=K_{S} \cdot c \cdot R \cdot T
$$

Azaz a só hozzáadása egy lineáris tagot ad hozzá a szabadenergiához, amely növeli, vagy csökkenti azt $K_{S}$ elöjelének megfelelően.

Frauenfelder és mtsi. [11] fehérjekonformációkkal kapcsolatos kiemelkedő munkájukban kimutatták, hogy egy fehérje makroállapota egy U-alakú szabadenergia-profillal közelíthető az $A_{f v}$ függvényében, melyet a 2 . ábra szemléltet. Az alsó határa ennek a görbének az összenyomhatósági- $\left(A_{1}\right)$, míg a felső a kinyújthatósági határ $\left(A_{2}\right)$. Ezen határok között csak kisebb energiagátak választják el egymástól az egyes állapotokat szobahőmérsékleten (vagy magasabb hőmérsékleten), melyek között viszonylagosan szabadon fluktuálhat a fehérje szerkezete a SASA értékét változtatva. A 2. ábra így egy sematikus ábrázolás, mivel a különböző színekkel rajzolt energia profilokat úgy kell értelmezni, hogy azok $A_{1}$ és $A_{2}$ közötti szakasza nem teljesen sima, hanem kisebb energiagátak következtében egyenetlen, vagy „rögös”, és a felrajzolt egyenes egy közelítés. Az I mennyiség pedig egy stabilitási paraméter, amit az elérhető $A_{f v}$ értékek segítségével definiálhatunk az energia minimum feletti $k_{B} \cdot T$ magasságban, ahol $k_{B}$ a Boltzmann állandó, T pedig az abszolút hőmérséklet. 


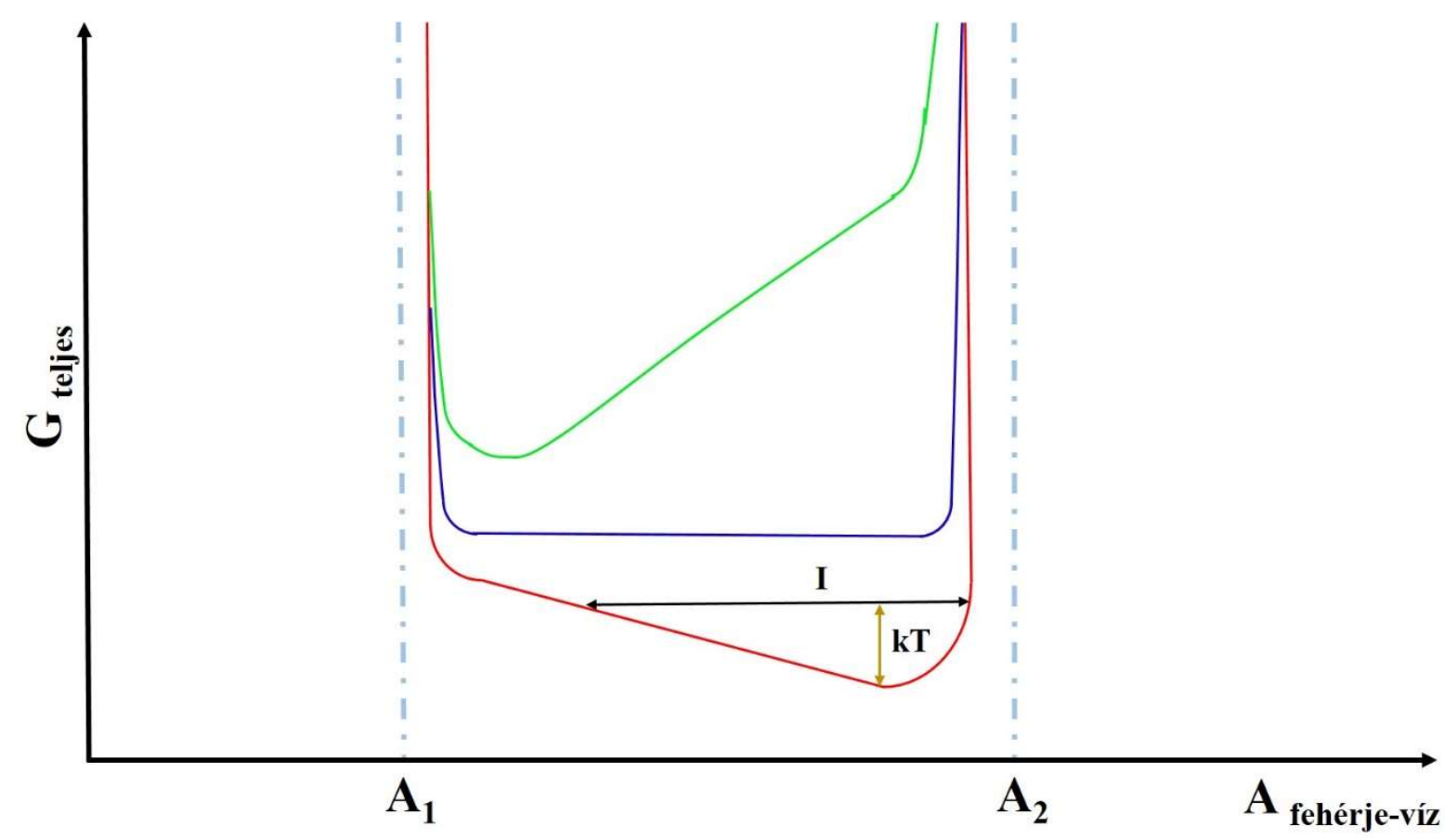

2. ábra Sematikus ábrázolása a teljes oldódási szabadenergiának a fehérje-víz határfelület felszínének függvényében. A három megkülönböztetett fehérje család különböző színekkel jelölve.

Figyelembe véve, hogy a különböző fehérjék esetében más-más aminosavak találhatóak a fehérje-víz határfelületen (és a Setschenow-konstans is függ a vizsgált fehérjétől), ezért nem biztos, hogy minden fehérje úgy viselkedik, mint ahogy azt a 2. ábrán a kék görbe leírja. Valójában, az eddig vizsgált fehérjék többsége a 2. ábrán zöld görbével $\left(\Delta \gamma_{f v}>0\right)$ jellemezhető családba tartozik, ekkor a zárt fehérjekonformáció a jellemző. Ebben az esetben a kaotróp sók destabilizáló hatásúak, a kozmotróp sók pedig stabilizálják a térszerkezetet, ahogy azt számos kísérleti tapasztalat is igazolja [2,3]. Azonban létezik számos kivétel is, amikor a kozmotróp és kaotróp sók másként viselkednek, mint ahogy a fenti szabály szerint feltételezhető. Némely esetben a kaotróp sók stabilizálják a kiindulási szerkezetet [2], vagy növelik a fehérjeaktivitást $[19,52]$, más esetekben mind a kozmotróp, mind a kaotróp sók stabilizáló hatással rendelkeznek [2]. A 2. ábrán látható piros $\left(\Delta \gamma_{f v}<0\right)$ és kék színü görbékhez tartozó fehérjecsaládok esetén lépnek fel föként ezek a jelenségek. Ezért nem általánosan igaz az az állítás, ami szerint a kozmotróp sók stabilizálják a fehérje térszerkezetét, míg a kaotrópok hatása ellentétes. (Valószínüleg onnan ered ez az elképzelés, hogy a natív „nyitott” térszerkezet ritka). Az ilyen jelenségek általában nehezen értelmezhetőek számos elméleti leírás keretén belül, azonban teljesen természetes módon felmerülő esetek a határfelületi feszültség koncepciójában.

A 2. ábrán felvázolt elképzelés HE-ra történő alkalmazása nyomán az is várható, hogy egyensúlyi állandók és átmenti arányok is megváltoznak olyan reakciókban, ahol jelentős konformációs változások lépnek fel (beleértve makromolekulák nagymértékü SASAváltozását, vagy szupramolekuláris szerkezetek megváltozását). Ezt az elképzelést nemrég sikeresen alkalmazták a HE hatására bekövetkező jelentős szerkezeti változások azonosítására 
a fotoaktív sárga fehérje (PYP) esetében [53], hierarchikusan felépülő fotoszintetikus pigment komplexeken [54] és DNS-fehérje komplexeken [55] is.

Ugyanakkor ez az U-alakú energiaprofil elképzelés a korábbi feltételezések indoklásában és értelmezésében is alkalmazható, például a (9) egyenlet feltételezi, hogy a határfelületi szabadenergia-változás során a (4) egyenletben szereplő $G_{0}$ szabadenergia tag konstans marad az oldódási környezet megváltozása során. Ez egy erős közelítés, mivel a fehérjén belüli intramolekuláris kölcsönhatások is megváltozhatnak az oldódási környezet megváltozásának következtében. Például, az ionok jelenléte gyengítheti a sóhidakat, hidrofób kölcsönhatásokat, vagy a H-kötéseket. Ez azt jelentené, hogy a 2. ábrán vázolt szabadenergia profilok ténylegesen simák az $A_{1}$ és $A_{2}$ határok között. Másfelől, egy fehérje kiindulási szerkezetében, ha egy töltött oldallánccal rendelkező aminosav ,eltemetett”, majd oldószernek kitett állapotba kerül, akkor mindez a (4) egyenletben feltételezett lineáris viselkedést módosíthatja, mivel egy töltött csoport oldódása nagyobb mértékü szabadenergia-változást eredményez. Mindazonáltal a globuláris fehérjéket tekintve a töltött csoportok jellemzően az oldószernek kitett felszínen találhatóak és a nagy mennyiségben ,eltemetett” töltött csoportok inkább a kivételhez tartoznak és ritkábban fordulnak elő. Ezért például olyan konformációs változás során, amit nagy SASAnövekedés kísér, mint mondjuk egy hidrofób mag felbomlása, az oldószernek kitett „új” felületen többségében hidrofób tulajdonságú aminosavak megjelenése a jellemző. Így az oldószernek kitett töltött csoportok számának jelentős változása nem valószínű konformációs változások (vagy fluktuációk) során a „hétköznapi” fehérjék müködése esetében, ill. ilyen típusú fehérjéket ír le pontosan a határfelületi feszültség koncepció. Természetesen, nemcsak a töltött- és nem töltött csoportok oldódási tulajdonságai között van különbség, hanem ez minden aminosav esetén fennáll, aminek szintén hatása lehet a (4) egyenlet szerinti lineáris összefüggésre. Azonban, ha a SASA-változás során valóban csak akkora különbségek vannak a vizsgált rendszer állapotai között, hogy a 2. ábrán szemléltetett U-alakú energiaprofil jó közelítés, akkor a (4) egyenlet lineáris összefüggése tartható, és a határfelületi feszültség koncepció által felvetett átlagos felületi feszültség érték bevezethető.

Összességében, ez a leírási mód a fehérje és a víz közötti határfelületen fellépő felületi feszültséget jelöli meg, mint központi jelentőségű fizikai mennyiséget, ami a HE szerteágazó előfordulásainak leírására szolgál. Az elméletből eredő legfontosabb megállapítás, hogy a kozmotróp, vagy a kaotróp sók jelenléte növeli, illetve csökkenti határfelületi feszültséget. Megmutatták továbbá, hogy a határfelületen fellépő felületi feszültség és a fehérje szerkezeti stabilitása közötti összefüggés közvetlenül összekapcsolható a fehérje konformációs fluktuációival [21]. Annak ellenére, hogy a határfelületi feszültség koncepció segítségével sikeresen lehetett kezelni számos, a HE-hoz köthető problémát, közvetlen bizonyíték kísérleti nehézségek következtében a Hofmeister-aktív ionok által létrehozott határfelületi feszültség változás és a HE közötti kapcsolatra nincs.

Megjegyzendő még, hogy a felületi feszültség származtatása lehetséges nem SASA-alapú módszerekkel is. A $\gamma$ változás származtatható a felületi adszorpció hagyományos elméletét felhasználva. Nemrégiben Chen és Smith [56] átdolgozták az elméletet annak érdekében, hogy számítógépes szimulációs adatok vizsgálatára is könnyen alkalmazható legyen. Ebben az átdolgozott elméletben a határfelületi régió vizsgálatára a szimulációs rendszerben található 
egyes komponensek valószínüségi eloszlását (számsürüség) használja és a Kirkwood-Buff elméletnek megfelelő RDF-eket alkalmazza [57, 58] a tömbfázisbeli tulajdonságok jellemzésére. Ezzel a módszerrel lehetséges egy két komponensből álló rendszer, mint például víz és valamilyen oldott molekula esetében a felületi feszültségnek az oldott molekula számsürüség szerinti deriváltjának meghatározása. Nemrégiben Horinek és Netz [59] széleskörü vizsgálatokat végeztek a fehérjék szabadenergia-változásait illetően, amikor is tiszta vizes oldódási környezetből karbamid molekulákat tartalmazó oldódási környezetbe kerülnek. A munkájuk során a fent bemutatott módszert alkalmazták a karbamid által kiváltott felületi feszültség azonosítására.

Az implicit vízmodellek alkalmazásával [60] végzett szimulációkban is fontos szerepe van az oldódási szabadenergiának és a felületi feszültségnek. A számolások szükséges pontosságának eléréséhez a hidratáció elektrosztatikájának modellezése mellett szükséges a molekulák oldódási szabadenergiájának pontos meghatározása [61, 62]. Több implicit modellben az oldódási szabadenergia nem poláros járulékát egy lineáris kifejezéssel írják le, és a SASA segítségével határozzák meg, mely mennyiség egy effektív felületi feszültség értékkel skálázódik [63, 64]. Brooks és mtsi. [65] kisebb molekulák abszolút oldódási energiáit határozták meg több implicit vízmodell felhasználásával, összevetve eredményeiket explicit oldószeres rendszerekből származtatottakkal, és kísérleti eredményekkel jó egyezést mutattak. Hasonló vizsgálatokat végeztek Wenzel és mtsi. [66], továbbá van der Spoel és mtsi. szerves oldószerek esetében is végeztek oldódási szabadenergia számolásokat [67].

\subsection{A Collins szabály}

A felületi feszültség, mint a HE-t jellemző mennyiség sikeres eszköznek bizonyult kísérleti eredmények értelmezésében és szimulációs szempontból is vizsgálható mennyiség. Annak érdekében, hogy Hofmeister-aktív ionok által kiváltott határfelületi feszültség változásokat és az ezt kiváltó mechanizmusokat jobban megérthessük a fehérje-víz határfelületi réteg részletesebb vizsgálata szükséges. A kozmotróp és kaotróp ionok felhalmozódása a határfelület közelében általában ellentétes jellemzőkkel rendelkezik. Ahogy azt kísérletileg is kimutatták a kozmotróp ionokra jellemzőbb a felhalmozódás ebben a régióban [2], aminek következtében általában a felületi feszültség csökken. Ezt a felhalmozódást első sorban az oldószernek kitett töltött atomok határozzák meg. Másfelől, ezen töltött atomok közvetlen környezetének jellemzői is befolyásolják a lokális ion sűrüséget. Ilyen például az oldási környezetnek kitett töltést tartalmazó felület geometriája (mennyire homorú, konkáv), ahogy azt Gibb és munkatársai is kimutatták [68]. Mindez az ionok anizotróp felhalmozódást eredményezi, melyek a fentebb leírt módon lokálisan megváltoztatják a vízszerkezetet és a kialakuló H-híd kötések erősségét és emellett magával a fehérjével is kölcsönhathatnak. A felhalmozódási különbségek értelmezésében és a fehérje-ion kölcsönhatás vizsgálatában a Collins szabály hasznos eszköznek bizonyul.

Az egyes töltött atomok, vagy atom csoportok közötti párformálódási / kölcsönhatási lehetőségeket három csoportra osztottuk: közvetlen /kontakt/ pár (CP: contact pair), oldószer 
által közvetített pár (SSP: solvent separated pair) és 2 oldószer által közvetített pár (2SP: two solvent pair). A 3. ábra szemlélteti ezeket a párképződési-, kölcsönhatási típusokat.

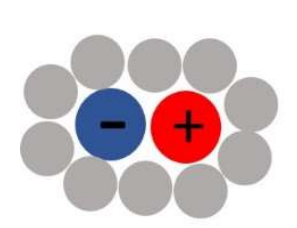

(A)

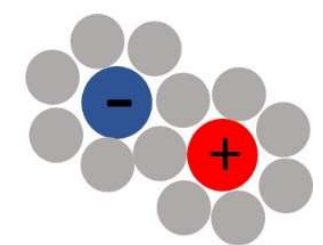

(B)

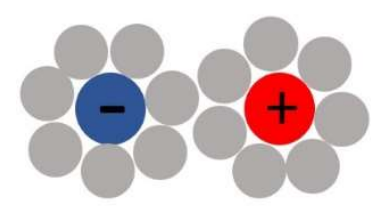

(C)

3. ábra A CP (A), SSP (B) és 2SP (C) típusú kölcsönhatások.

Collins és munkatársai mintegy évtizeddel ezelőtt kimutatták [22], hogy kapcsolat áll fenn a vízben oldott anionok és kationok párképzési affinitása és Hofmeister aktivitása között. Az általuk megfogalmazott „összeillő víz-oldékonyság törvénye” (melyet alkáli halogének oldhatóságára alapoztak) szerint azok az ellentétes töltésü ionok preferálják a párformálást, amelyek hasonló az oldhatósággal rendelkeznek.

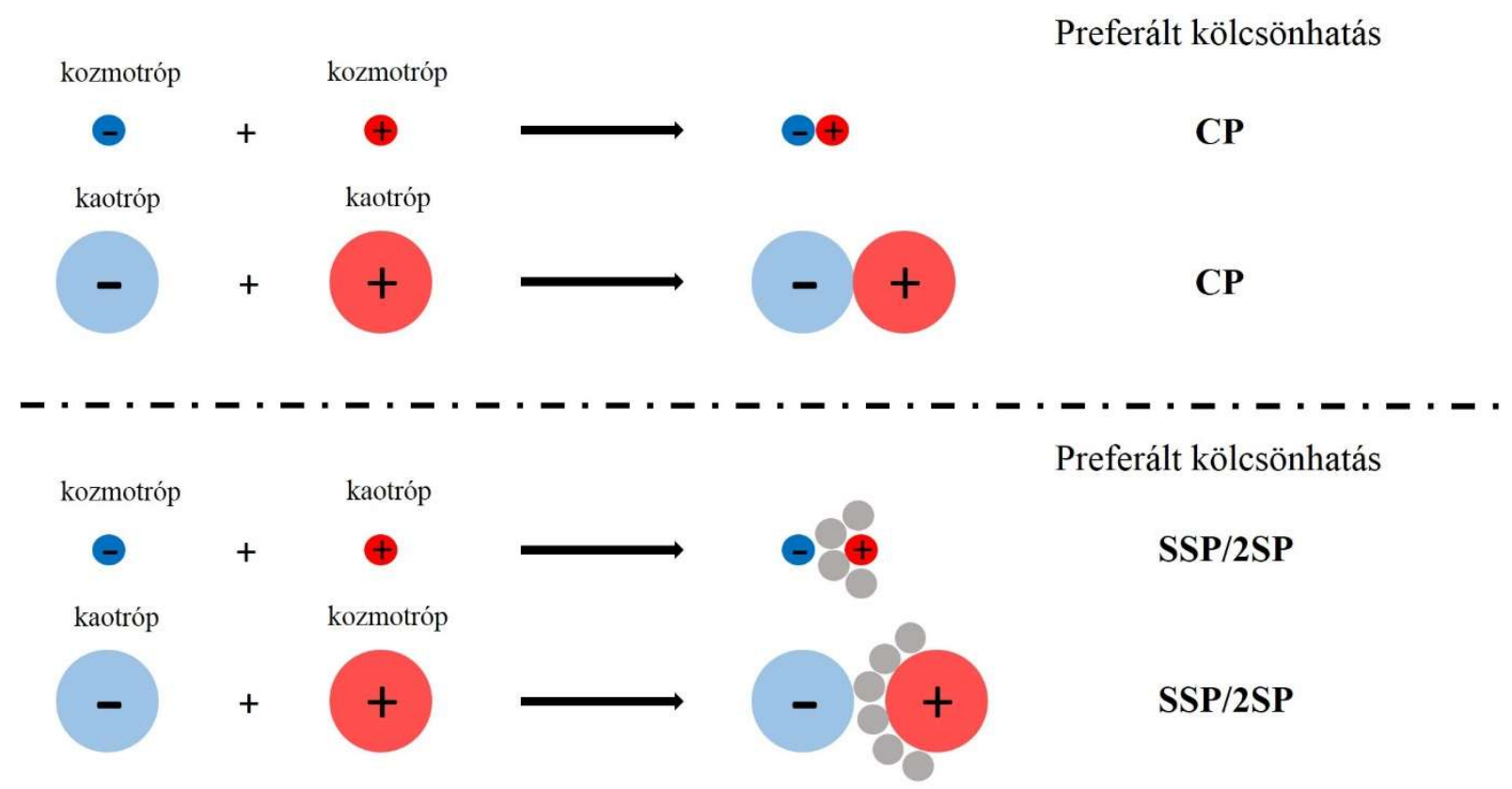

4. ábra A Collins szabály szerint a preferált párképződés[22]. 
Collins hangsúlyozta továbbá, hogy az oldódási aktivitás, azaz a hidratáció erőssége úgy kapcsolódik a Hofmeister aktivitáshoz, hogy a kaotróp ionok a gyengén-, míg a kozmotróp ionok az erősen hidratált ágensek $[69,70]$. Következésképpen a stabil ion párok csak kaotrópkaotróp, illetve kozmotróp-kozmotróp tulajdonságú ionok között jöhetnek létre, míg egyéb esetben az ion párokra inkább jellemző, hogy részben, vagy egészben megtartják a saját hidratációs burkukat (4. ábra).

Mint azt kimutattuk, ez a koncepció általánosítható fehérjék és ionok közötti kölcsönhatásokra, illetve töltött felszíni csoportok és ionok közötti párképzés sajátságainak vizsgálatára is. Collins osztályozását szem előtt tartva a fehérjék javarészt kaotróp építőelemekből állnak, mint semleges amid- és szénhidrogén csoportok, vagy protonált guanidinium- és amino csoportok. Egyedüliként erősen hidratáltnak, azaz kozmotrópnak, tekinthető csoport a karboxilcsoport, amely így várhatóan rendelkezik párképzési affinitással a kozmotróp ionok tekintetében. Nemrégiben kísérleti- és szimulációs eszközökkel is kimutatták közvetlen kölcsönhatás jelenlétét fehérjék és a fehérje-víz határfelületen felhalmozódott kaotróp anionok között [7174].

\subsection{Modellrendszer: tc5b minifehérje}

A Trp-kalitkát (5.ábra), vagy más néven tc5b minifehérjét mind szimulációs-, mind kísérleti módszerekkel széles körben vizsgálták [28, 29, 34-36]. Mindennek köszönhetően a térbeli struktúrája már jól karakterizált (az NMR szerkezet az 1L2Y PDB kód alatt elérhető). A tc5b népszerüsége főként kis méretének, stabil és kompakt térszerkezetének, illetve ez utóbbinak hőmérséklet-változással szembeni érzékenységének köszönhető. Továbbá megjegyzendő, hogy nagyon rövid, mikroszekundumos időskálán veszi fel a térszerkezetet, amely olyan szimulációs időt jelent, ami napjainkra MD eszközökkel kezelhető. Ez a minifehérje egy mindösszesen 20 aminosavból álló oligomer, melyet Neidigh és munkatársai [28] terveztek 2002-ben; a szekvenciája a következő: NLYIQ WLKDG GPSSG RPPPS. 


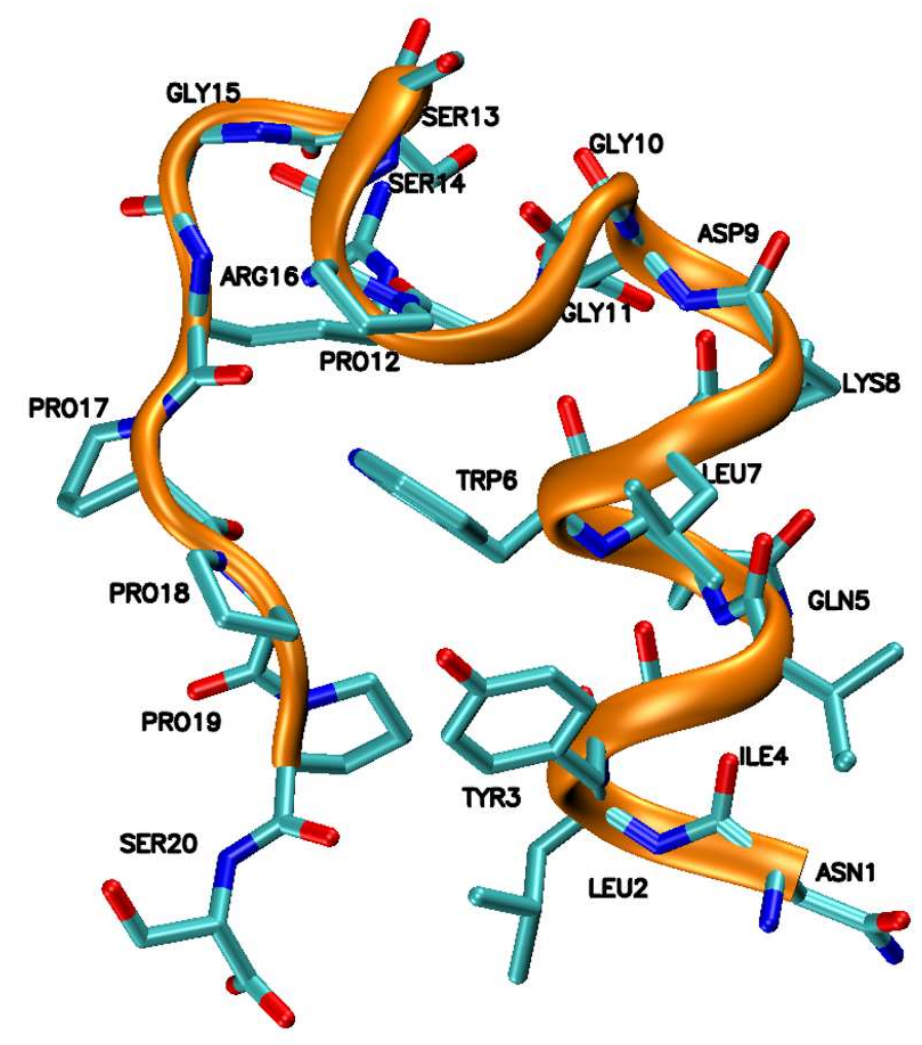

5.ábra A tc5b minifehérje térszerkezete.

A minifehérje elnevezés onnan ered, hogy kis mérete ellenére megtalálható benne több olyan másodlagos- és harmadlagos szerkezeti elem, ami általában csak jóval nagyobb rendszerek sajátja. A térszerkezete tartalmaz egy hosszabb, az N-terminálisnál kezdődő $\alpha$-helikális szegmenst, ezt követően egy $\beta$-kanyar szerkezetet és egy PP-II hélixet a C-terminális közelében. Mindemellett, tartalmaz egy hidrofób magot, melyet fóként a $\operatorname{Tyr}^{3}$ és a $\operatorname{Trp}^{6}$ aminosavak oldalláncaiban található gyürük összetapadása (stacking) és a Pro ${ }^{12}$, Pro ${ }^{17-19}$ aminosavak alkotnak. Megtalálható egy sóhíd is a tc5b szerkezetében, mely az Asp ${ }^{9}$ és az $\operatorname{Arg}^{16}$ aminosavak között formálódik. Mind ez utóbbi, mind a korábban említett hidrofób kölcsönhatások együttes jelenléte különösen alkalmassá teszik ezt a modell rendszert a HE vizsgálatára, mivel eltérő módon változtathatják meg ezeket az ellentétes hatású Hofmeister-aktív ionok. Ugyanakkor vizsgálhatjuk az ionok hatását a szerkezeti elemekre, vagy a térszerkezet stabilitására való tekintettel, továbbá azonosíthatjuk az eltérő tulajdonságú felületek mentén az ionok felhalmozódási jellemzőit is. 


\section{Szimulációs előzmények és lehetőségek}

A HE számítógépes eszközökkel történő vizsgálatával kapcsolatban már számos elméleti és kísérleti munka született. Dzubiella és munkatársainak nemrégiben több részletes vizsgálata [24-26] bemutatta a Hofmeister-aktív halogének alkáli sóinak (nagy koncentrációban) töltött aminosavakat és sóhídakat tartalmazó, jelentős helikális tartalommal bíró alanin alapú polipeptidek stabilitására gyakorolt hatását. Ezek MD szimulációk voltak és nem polarizálható erőterek felhasználásával készültek. Asciutto és munkatársai [27] alacsony koncentrációban jelen lévő perklorát ionok szerkezet stabilizáló hatását mutatták ki az AAAAA(AAARA) 3 A modellrendszeren.

A tc5b térszerkezetét és annak kialakulását számos kísérleti és szimulációs módszerrel vizsgálták eddig, a fent említett előnyös tulajdonságai miatt. Garcia és munkatársai mikorszekundum hosszúságú REMD számolásokat végeztek [32], melyek a tc5b minifehérje feltekeredését (folding) vizsgálták. Mindemellett elemezték két vízmodellnek (TIP3P és TIP4P-EW) a minifehérje szerkezeti stabilitására gyakorolt hatását [33]. A minifehérje karbamid és guanidinium által kiváltott denaturálódásának molekuláris mechanizmusát Heyda és mtsi. térképezték fel kísérleti módszerek és hosszú MD számolások segítségével [72]. Hasonlóan a karbamid hatását vizsgálták Canchi és munkatársai REMD szimulációk segítségével [75], a folyamat termodinamikai jellemzőire koncentrálva. A tc5b szerkezetének a hőmérséklet növelésének hatására bekövetkező felbomlását is vizsgálták mind kísérleti, mind elméleti eszközök segítségével. Mindezek ellenére még mindig vannak nyitott kérdések, mint például a töltött oldalláncok és a sóhíd szerepe [76, 77], továbbá, hogy két- [78], vagy több állapotú-e [79] az átmenet. Halabis és mtsi. kimutatták [36], hogy a tömbfázisbeli térszerkezetfelbomlás úgy írható le, mint a hidrofób kölcsönhatások meggyengülése (föként a hosszútávú kölcsönhatások, különösen a $\operatorname{Trp}^{6}-\mathrm{Pro}^{12}$ ) és az N-terminálisnál található $\alpha$-hélix szétesése. Ugyanakkor a rövidtávú hidrofób kölcsönhatások még hamarabb meggyengülnek, és a sóhíd is felbomlik. Több szimulációs munka is foglalkozott a hőmérsékleti destabilizációs folyamat leírásával, némely azonban irreálisan magas átmeneti hőmérsékleteket eredményezett, például megközelítőleg 440 K-t [31, 75], amelyek nem voltak összeegyeztethetők kísérleti adatokkal. Ahmed és mtsi. UV rezonancia-Raman spektroszkópiai módszerrel (UVRS) megmutatták [80], hogy a Trp ${ }^{6}$ még $343 \mathrm{~K}$-en is ,el van temetve” a hidrofób magban. Emellett az $\alpha$-helikális amid kötések számát is megbecsülték az N-terminálisnál található releváns szegmenset vizsgálva. Azt találták, hogy 298 K-ig nincs változás, részleges a leolvadás az $\alpha$-hélixben $343 \mathrm{~K}$-en és az átmeneti hőmérséklet $313 \mathrm{~K}$ közelében van, ami nincs összhangban a Neidigh és mts által CD mérések alapján megállapítottakkal [28]. Emellett a hőmérséklet 298 K-ről 343 K-re növelésével a $\mathrm{Tyr}^{3}$ aminosav eltávolodik a C-terminálison található prolintól, ezzel kinyitva a szerkezetet, míg a Trp ${ }^{6}$ oldószer-kitettsége közel lineárisan növekszik, de a hidrofób mag nem esik szét teljesen. Ezek a folyamatok természetesen megváltoztatják a SASA értékét és a folyamatot várhatóan befolyásolják a Hofmeister-aktív ionok is.

Ahogy azt több munkában is kimutatták, az ionok oldódásával kapcsolatos fizikai mennyiségek kellően pontos kiszámítása nem lehetséges polarizálható erőterek alkalmazása nélkül [81, 82]. Ugyanakkor Kalcher és mtsi. meg tudták határozni halogén ionok $\left(\mathrm{F}^{-}, \mathrm{Cl}^{-}, \mathrm{I}^{-}\right)$által kiváltott 
felületi feszültség változások értékét vákuum-víz határfelületen MD módszerek segítségével és nem polarizálható erőterek alkalmazásával [24]. A kapott értékek a kísérleti trendet követik, nevezetesen, minél nagyobb az ion, annál kisebb a felületi feszültség növekedése. Sun és mtsi. szintén a vákuum-víz határfelületen fellépő felületi feszültség változásokat vizsgálták [23] halogének nátrium sói esetében nem polarizálható erőtérrel és szemi-flexibilis SPC/E vízmodell segítségével. Az eredményeik jó pontossággal visszaadták a kísérleti adatokat: 3,6; 2,6 és 1,5 $\mathrm{mN} / \mathrm{m}$ növekedés a felületi feszültségben rendre a $\mathrm{NaF}, \mathrm{NaCl}$ és $\mathrm{NaI}$ sókra, 1,2 mólos koncentrációban.

Az ionok oldódását és a kation-anion kölcsönhatásokat tekintve több független tanulmány is hangsúlyozza a kvantummechanikai effektusok fontosságát [83-87]. Mindazonáltal, explicit vizes szimulációk is konzisztens eredményeket szolgáltatnak, ha a diszperziós kölcsönhatások megfelelően vannak kezelve a Lenard-Jones kölcsönhatás $r^{-6}$ tagján keresztül [84]. Továbbá, az elérhető szimulációs idő az olyan nagy rendszerekre, mint egy oldott fehérje erősen korlátos, ha a kvantummechanikai számolásokat legalább részben használó szimulációkat alkalmazunk (mint például QM/MM, vagy Born-Oppenheimer MD). Annak érdekében, hogy az ionok által kiváltott szerkezeti változásokat feltérképezhessük hosszú MD számolások kellenek, ahogy azt korábban több tanulmány is kimutatta [25, 88]. Mindez ezért szükséges, hogy elérhessük az egyensúlyi állapot és a mintavételezés is elégséges mértékü legyen, és ez minden bizonnyal igaz a kvantummechanikai alapú módszerekre is. Ennek megfelelően számos explicit vízmodellt használó, egyaránt polarizálható, és nem-polarizálható erőteres MD szimulációk készültek, melyek olyan kérdésekkel foglalkoztak, mint: ion-víz kölcsönhatások és kapcsolódó HE fehérjék esetében [73, 89-92], DNS-kation kölcsönhatások [93-95]. Megállapítható, hogy néhány látványos kivételtől eltekintve, mint például a szulfát ionok esete [96], a polarizálható és nem-polarizálható erőterek általában ugyanolyan jól müködtek [97, 98]. A tc5b minifehérje esetén egy nem polarizálható erőteres MD számolás szintén sikeres lehet aminosav alapú ionos folyadékok és vizes oldatuk esetében, ahogy ezt Chevrot és mtsi. kimutatták [99]. Ugyanakkor megjegyzendő, hogy DFT-alapú Born-Oppenheimer MD számolásokat végeztek Willow és mtsi. [100], melyek egy modellfehérje esetén származtattak felületi feszültség értékeket, azonban a mintavételezés és a szimulációs idő is erősen korlátozott volt, az utóbbi pikoszekundumos nagyságrendü volt 130 vízmolekula jelenléte mellett. 


\section{Célkitüzés}

Figyelembe véve a korábbi szimulációs tapasztalatokat és ötleteket, továbbá a rendelkezésre álló kísérleti eredményeket, ennek a munkának a célja, hogy MD szimulációs eszközök segítségével megvizsgáljuk a tc5b fehérje tulajdonságait különböző oldódási környezetekben. Kozmotróp, kaotróp, és Hofmeister-semleges ionok hozzáadásával és különböző szimulációs hőmérsékletek alkalmazásával az alábbi feladatokra fókuszáltunk:

Megmutatjuk, hogy a tc5b minifehérje a választott szimulációs feltételekkel olyan modellt alkot, amelyben a vizsgált ionok jelenlétében a Hofmeister sornak megfelelő szerkezet-stabilitási különbségek azonosíthatók.

Modellrendszerünkben a Hofmeister-aktív sók által kiváltott, oldószer számára hozzáférhető felület változások felhasználásával meghatározzuk a vizsgált sók jelenlétében fellépő határfelületi feszültség változásokat. Megmutatjuk, hogy ezek a szimulációs eredmények összhangban vannak a Dér és mtsi. által kidolgozott határfelületi feszültség koncepcióval [20,21].

* A tc5b minifehérje és a hidratációs környezete közötti határfelületen azonosítjuk az kiválasztott Hofmesiter-aktív ionok felhalmozódási tulajdonságait, és az ennek következtében fellépő változásokat a határfelületi vízmolekulák orientációs dinamikájában

Meghatározzuk a vízben oldott minifehérje és környezete közötti kölcsönhatások különbségeit, ha az oldatban nincsenek Hofmeister-aktív ionok, illetve, ha kozmotróp fluorid, vagy kaotróp perklorát ionokat tartalmaz. A tc5b minifehérje és környezete közötti kölcsönhatási energia-eloszlásban csakúgy, mint a legközelebbi ionok távolságeloszlásában is azonosítjuk a különbségeket.

* Számítógépes szimuláció során mesterségesen két részre bontjuk a kaotróp perklorát és a kozmotróp fluorid ionok által a tc5b minifehérje vizes oldatában indukált folyamatokat. Az első, felhalmozódási szakaszban a rögzített fehérje-felület közelében kialakuló ioneloszlásokat, illetve hidratációs változásokat; a második átrendeződési szakaszban pedig a minifehérje szerkezeti átrendeződése során létrejövő további változásokat is írtjuk le. Eredményeink alapján azonosítjuk a tc $5 \mathrm{~b}$ minifehérje kaotróp destabilizációjának és kozmotróp stabilizációjának meghatározó mozzanatait. 


\section{Módszerek}

\section{Biomolekuláris rendszerek számítógépes modellezése alapvetően a statisztikus}

termodinamikán alapul. A célja az, hogy egy erősen korlátozott méretű modellrendszer segítségével származtassuk a valós rendszer tulajdonságait. Az utóbbi évtizedek számítástechnikai és metodikai fejlesztéseinek köszönhetően szerteágazó lehetőségek állnak rendelkezésre. Az alkalmazott módszer és programcsomag nagymértékben függ a vizsgálni kívánt jelenségtől, a modellrendszer nagyságától, a rendszer atomi összetételétől stb. Az ebben a munkában bemutatott eredményeket molekuladinamikai (MD) módszerek felhasználásával származtattuk. Ezt a szimulációs módszert, a használt beállításokat és a kiértékelések módját tekintjük át ebben a fejezetben.

\subsection{Molekuladinamikai szimulációk}

\subsubsection{MD szimuláció általában}

A molekuladinamikai szimulációs eljárások alapvetően két főbb csoportba sorolhatók: kvantummechanikán alapuló módszerek ( $a$ b initio számolások, sűrüségfunkcionál alapú (DFT) módszerek stb.) és klasszikus erőterek használatán alapuló módszerek. Egy adott szimulációs eljárás kiválasztása kompromisszum kérdés is egyben, melyet az elvárt pontosság, a számítási igény, maga a vizsgált jelenség és a modell rendszer is befolyásol. A klasszikus potenciálokat alkalmazó molekuladinamikai megközelítés széles körben alkalmazott és elfogadott módszer, mivel több biológiailag- és kémiailag releváns kérdést illetően kezelhető kompromisszumok mellett használható. A molekuladinamikai szimulációk kivitelezésére számos programcsomag áll rendelkezésre, ilyenek például az Amber [101], CHARMM [102], NAMD [103] és a GROMACS [104]. Minden klasszikus MD szimuláció alapja a newtoni mozgásegyenlet lépésenkénti integrálása numerikus módszerek alkalmazásával, illetve az egyes atomok helykoordinátáinak és sebességeinek meghatározása. Ezekben a szimulációkban a vizsgált molekulákat felépítő atomokhoz tartoznak konstans paraméterek: tömeg, parciális töltés, van der Waals sugár, azonban a polarizáció kezelése és a töltésátadás az esetek többségében nem lehetséges. Ennek a módszernek az egyik legnagyobb előnye, hogy alkalmazható olyan nagy molekulák konformációs terének feltérképezésére, mint például egy adott hidratációs környezetben található fehérje. Az alkalmazott MD protokoll, a szimulációs idő, továbbá az alkalmazott algoritmusok és egyéb MD beállítások mind hatással vannak az eredményként kapott trajektóriára és az ehhez tartozó konformációs sokaságra. A kísérleti eredményekkel történő összehasonlításhoz általában szükséges egy megfelelő mintavételezésű, egyensúlyi állapothoz tartozó sokaság származtatása. Mindez alapvető fontosságú, mert a megfelelő pontosságú mintavételezéssel rendelkező, ergodikus sokaságokban az időbeli- és a sokaságra vonatkozó átlagolás felcserélhető, és ez által származtathatóak termodinamikai- és egyéb statisztikus eredetü mennyiségek is.

Azonban a megfelelő mértékü mintavételezés az atomi szinten történő, nem klasszikus számolások esetén jelenleg nem megoldott probléma. A magas szintü kvantumkémiai ab initio 
eljárások maximum pár száz atomos nagyságrendre korlátozódnak. Továbbá, ezen módszerek alkalmazása nem teszi lehetővé a biológiailag releváns időtávok szimulálását (például fehérjefeltekeredés, aggregációs folyamatok, stb.), hanem általában pikoszekundumos korlátok a jellemzőek. Ezzel ellentétben a klasszikus potenciálokot alkalmazó MD módszerek több tízezres, akár több százezres atomszámot tudnak kezelni. Ez azért is lényeges különbség, mert így oldószer molekulákat, ionokat is alkalmazhatunk nagyobb modellrendszerekben, melyek jelenléte alapvető fontossággal bír például a fehérjék térszerkezetének kialakításában és annak stabilitásában. Mindazonáltal, ezt a módszert használva is általában csak kevés számú vizsgált molekula van jelen a modellrendszerben, összevetve például 1 mólnyi anyagmennyiséggel. Az elérhető szimulációs időtávok mellett (melyek akár mikroszekundumos nagyságrendüek) egyegy vizsgált molekula adataiból eredeztethetőek nagyszámú molekula tulajdonságait leíró eredmények a statisztikus megközelítés segítségével.

Továbbá, egy klasszikus MD számolás során olyan, a rendszer állapotát leíró adatokat generálunk, amelyek az idő függvényei. Ez a tulajdonság egy jelentős különbség a Monte Carlo szimulációkhoz képest (melyek inkább sztochasztikus algoritmusok, mint valós dinamikák), mivel így lehetséges időfüggő tulajdonságok kiszámítása is. Ilyenek például két kiválasztott mennyiség között számolt korrelációs koefficiens, vagy relaxációs idők, autokorrelációs függvények, orientációs korrelációs függvények stb. A mintavételezés ezekben az esetekben is nagy jelentőséggel rendelkezik, például a numerikus zaj csökkentésének érdekében kellő mennyiségü adatot szükséges átlagolni.

A klasszikus mechanikán alapuló MD protokollok egyik korlátja, hogy nem alkalmasak a teljes mértékben kvantummechanikai jelenségek vizsgálatára, mint például kémiai kötések kialakulása, vagy azok felbomlása. Ugyanakkor, a klasszikus erőterekben használt paraméterek kvantummechanikai eredetűek (általában kisebb bázist és Hartree-Fock (HF) módszert alkalmazó számolások) és gyakran a kísérleti eredményekkel való jobb egyezés szerint korrigáltak.

Megjegyzendő továbbá, hogy a klasszikus potenciálok és a tömegpontokra történő redukálás segítségével történő leírás közelítéseket tesz szükségessé, hiszen olyan atomi / molekuláris rendszereket vizsgálunk, amelyeket ideális esetben kvantummechanikai kezelést igényelnek. A legpontosabb vizsgálatokhoz természetesen tisztán kvantummechanikából származtatott potenciálra van szükség. Ennek következtében mára már elérhetőek elterjedt és kipróbált módszerek, melyek a klasszikus és a kvantum potenciálok ötvözésével müködnek, miszerint a rendszer egy kis részében kvantummechanikai, a kimaradó részében pedig klasszikus potenciált használunk, ezek a QM/MM módszerek [105]. Továbbá vannak olyan tisztán kvantummechanikát alkalmazó dinamikák is, amelyekben periodikus határfeltételek mellett oldószer molekulák és hömérsékleti csatolás is alkalmazhatóak kisebb rendszerekre, azonban ez utóbbiak roppant nagy számítási igényekkel rendelkeznek, aminek következtében a klasszikus MD módszerek méret- és szimulációs idő korlátai még mindig elérhetetlenek. 


\subsubsection{Erőterek}

A molekuladinamikai szimulációkban szükséges meghatározni, hogy az egyes atomok milyen módon lépnek kölcsönhatásba egymással, ehhez elengedhetetlen a potenciálfüggvények definiálása. Ezen függvények összességét szokás erőtérnek nevezni. Sokféle módon lehet erőtereket definiálni a kölcsönhatások leírására, ezek az erőterek természetesen függnek a megoldani kívánt problémától, de általában konformációs változások vizsgálatára jóval alkalmasabbak, mint kémiai reakciók tanulmányozására, melyre csak kevés erőtér képes, ilyen például a ReaxFF [106]. A MD számolás során az atomok között fellépő erőket a potenciális energia negatív gradiensének segítségével határozhatjuk meg az atomtömegek ismeretében. Az egyes MD programcsomagokban általában saját fejlesztésű, kipróbált, jól müködő erőterek választhatóak (mint például Amber erőterek [107], GROMOS erőterek [108], OPLS erőterek [109, 110] stb.), melyek a mai napig optimalizálás tárgyai. A potenciális energia komponensek származtatása többféle módon lehetséges, számos algoritmus használatával, melyek általában programcsomagonként eltérőek.

Az erőterekben szereplő erők két részre oszthatók: a kémiai kötéshez kapcsolódó erők (kötéstávolság, kötésszög stb.) és elektrosztatikus jellegü erök. Egy molekula teljes energiájának minden egyes összetevőjéről feltesszük, hogy függetlenek egymástól. Ezek az energiák a következők: Ektáv a kötések megnyújtásából származó energia, Ekszög a kötésszög megváltozásából származó energia, $E_{\text {tor }}$ a torziós szög megváltozásából származó energia, $E_{\mathrm{el}}$ az elektrosztatikus kölcsönhatásból eredő energia és EVdw a van der Waals kölcsönhatásból származó energia:

$$
E_{M D}=E_{k t a ́ v}+E_{k s z o ̈ g}+E_{t o r}+E_{e l}+E_{V d W}
$$

Az első három tag összessége adja a kovalens kötésekből adódó (kötő-) energia járulékot, míg utolsó két tag a nem-kovalens (nem kötő-) járulék. A potenciálfüggvények alakja természetesen függ az alkalmazott programcsomagtól, a bennük szereplő paraméterek (mint például: atomok töltése, Van der Waals paraméterek, kötéstávolság, kötésszögek, diéderes szögek stb.) pedig a választott erötértől is. Általában a kötéstávolsághoz és kötésszöghöz tartozó energiatagokat harmonikus potenciálokkal modellezik, a torziós szögekhez tartozó tag esetében pedig általában több minimum is megjelenik, így nem lehet harmonikus potenciálokkal közelíteni.

A nem kötő tagok általában összetettebb alakúak és nagyobb számítási időt is igényelnek, mint a kötő tagok, ezért gyakran közelítéseket kell alkalmazni. Ez annak a következménye, hogy MD rendszerekben egy tetszőlegesen kiválasztott atom általában elhanyagolható számú atommal alkot kémiai kötést a szimulációs rendszerben található összes atomhoz viszonyítva, viszont a nem kötő tagok minden más atommal számítandóak. A két szóban forgó energiatag közül a van der Waals jóval gyorsabb lecsengésü függvénnyel van modellezve, nevezetesen a 6-12 Lennard-Jones potenciállal. Ez azt jelenti, hogy a vonzó kölcsönhatásokat leíró tag $r^{-6}$ függvény szerint cseng le, míg taszítás esetén $r^{-12}$ szerint, ahol $r$ a két atom közötti távolságot jelöli. Az elektrosztatikus tag is jellemzően nagy számítási igényü és gyakran a nagyobb távolságokban fellépő elektrosztatikus kölcsönhatások is relevánsak, pl. fehérjék vizsgálatakor. Az elektrosztatikus kölcsönhatás esetén a Coulomb függvény az alapvető jelentőségü, mely 
$r^{-1}$-es lecsengéssel rendelkezik. Ezek kiszámítása szükíti leginkább a molekuladinamika mozgásterét, mivel rendkívül meghosszabbítja a szükséges számítási időt. A szükséges számítási idő mérséklésére használatban vannak bizonyos közelítések, mint például: periodikus határfeltétel, rögzített levágási sugár a nemlokális kölcsönhatásokra, PME (Particle Mesh Ewald) módszer [111] stb.

Mindkét nem kötő tag esetén lehetséges egy lecsengési távolságot választani, ami azt a távolságot jelenti, amin belül keresünk kölcsönható atom párokat és számítunk nem kötő energiákat minden atom esetén. Ugyanakkor egy bizonyos távolság után lehet egy nagyon gyors lecsengésü függvényt is alkalmazni a számításokra. Vannak azonban fejlettebb, viszont valamivel erőforrás-igényesebb algoritmusok, mint például a fent említett PME, ami az energia tagokat a Fourier-térben összegezi.

\subsubsection{Oldószermodellek}

A biológiailag és kémiailag releváns rendszerekben általában szükséges az oldószer jelenlétének figyelembe vétele is. Ennek a problémának a kezelésére különféle lehetőségek állnak rendelkezésre, melyek két nagy csoportja az implicit- és az explicit modellek. A számítási kapacitások növekedésével az utóbbi csoport az egyre inkább használatos és elfogadott. Az explicit oldószermodellekben molekulánként van jelen az oldószer (ellentétben az implicit modellekkel), ami a szimulációt tekintve nagyszámú további atom trajektóriájának és kölcsönhatásainak számolását teszi szükségessé. Biológiai rendszerekben ez az oldószer javarészt víz, ezért a vízmolekulákat illetően számos eltérő modell és ehhez kapcsolódó paraméterhalmaz kifejlesztése történt meg.

A fentiekben részletezett nagy számítási igénynek volt a következménye az implicit oldószer modellek elterjedése. Az ilyen típusú szimulációkban a modellrendszerben nincsenek jelen oldószer molekulák, hanem folytonos közegként veszik figyelembe az oldódási környezetet, ezzel csökkentve az egyes atompárok esetén szükséges számolásokat. A régebbi implicit modellek SASA-alapúak, melyek az oldódási szabadenergia közvetlen felhasználásával dolgoznak, az újabbak pedig a folytonos elektrosztatikus modellek. A SASA-alapú megközelítést követően az általánosított Born- (GB, generalized Born) modell játszott központi szerepet, ami a linearizált Poisson-Boltzmann egyenletet közelítésén alapult, de természetesen ebben az esetben egy oldódási szabadenergia kifejezést használunk az oldódási környezet leírására. A GBSA tulajdonképpen egy hidrofób SASA-taggal kiegészített általánosított Bornmodell. Ez a legelterjedtebb és a legszélesebb körben használt implicit oldószer modell. Ennek a módszernek megvannak a határai, szerkezeti információt és egyéb fizikai mennyiségeket kellő pontossággal csak kis atomszámú rendszerek, illetve néhány aminosavat tartalmazó oligomerek esetén szolgáltat. Ugyanakkor a módszer természetesen jellegénél fogva nem alkalmas az oldószer tulajdonságainak vizsgálatára. Napjainkban azonban a legelterjedtebbek az explicit oldószeres modellek, melyek jellemzője, hogy molekulánként van jelen maga az oldószer és esetleg az adott oldószer paraméterezésével együtt használható ionok is (megfelelő saját paraméterekkel). Számos oldószerként használt molekulára vannak elfogadott, megfelelő pontosságú eredményeket szolgáltató paraméterek, ilyenek például: víz, etil- és metilalkohol, 
DMSO stb. Természetesen a víz molekulákra található a legtöbb féle modell a legismertebbek a SPC [112], TIP3P [113], TIP4P [114] és TIP5P [115], SPCE [116]. Illetve az ezekből származtatott egyéb változatok, mint például a TIP4P/2005 [117], mely vízmodell arra a van optimalizálva, hogy a lehető legpontosabban adja vissza a víz kísérleti fázisdiagrammját (hasonló példák még: TIP4P/Ice, TIP4P-Ew [118]). A vízmodelleket három tulajdonság alapján kategorizálhatjuk: (1) hány kölcsönhatási pontból áll, (2) merev, vagy flexibilis és (3) polarizációs hatásokat kezel-e, vagy sem. Az 1-es tulajdonságot tekintve a legjellemzőbb a 3 (pl. TIP3P, SPC, SPCE), a 4 (pl. TIP4P, TIP4P/2005) és az 5 (TIP5P) és 6 kölcsönhatási pontot tartalmazó modellek, továbbá léteznek még 6 pontos vízmodellek is (6. ábra).

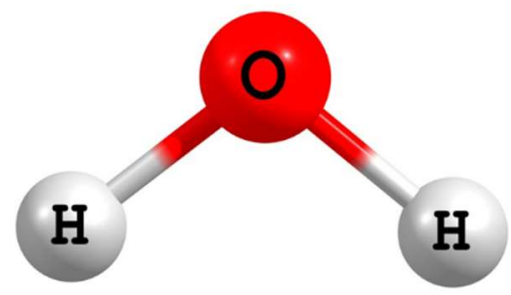

(A)

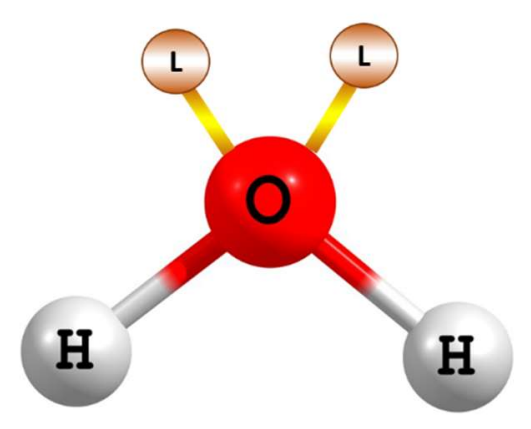

(C)

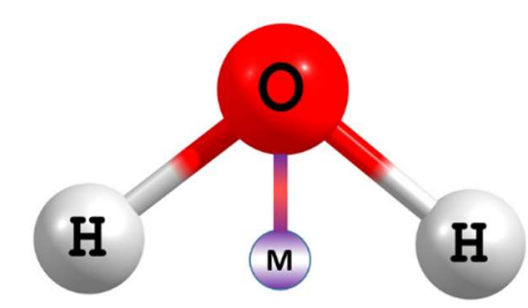

(B)

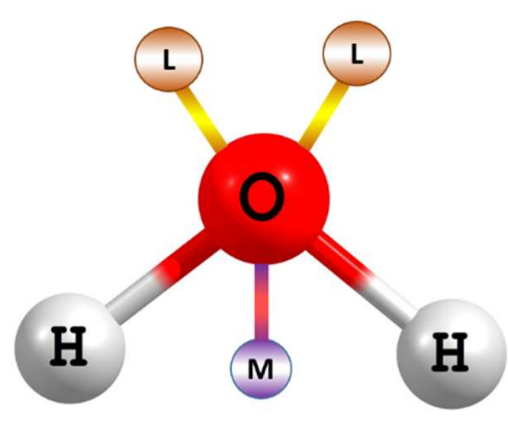

(D)

6. ábra A 3 (A), 4 (B), 5(C) és 6 (D) kölcsönhatási pontot tartalmazó vízmodellek.

A három-pontos vízmodellekben természetesen a három kölcsönhatási pont az oxigén atom és a két hidrogén atom. Minden atomhoz tartozik egy ponttöltés és az oxigén atom esetén LennardJones paraméterek is (némely erőterekben a $\mathrm{H}$ atomokhoz is tartoznak). Számítási szempontból ez a leghatékonyabb modell, mivel az tartalmazza a legkevesebb kölcsönhatási helyet. A hárompontos TIP3P, SPC és SPCE merev modellek, azaz a nem-kötő kölcsönhatások a legfontosabbak ebben az esetben, a kötő kölcsönhatásokra pedig erős geometriai kényszerek vonatkoznak. Az SPCE modell tartalmaz polarizációs korrekciókat, aminek következtében pl. a víz sürüségét jobban adja vissza, mint az SPC. Ugyanakkor az SPC-ből létezik flexibilis változat is.

A négy-, öt- és hatpontos vízmodellek úgynevezett „dummy atomokat” tartalmaznak, ezeket az atomokat $M$ és $L$ betü jelöli a 6. ábrán. Az M és $L$ atomoknak negatív töltése van és a céljuk, hogy jobban közelítse a vízmolekula elektronszerkezetét. A TIP4P és változatai csak egy M dummy atomot tartalmaznak, merev modellek, kivéve a pl. a q-TIP4P/f változatot. Az ötpontos modellek két $\mathrm{L}$ dummy atomot tartalmaznak az $\mathrm{O}$ atom körüli magányos pár pályát modellezik, 
tetraéder-szerü térszerkezettel. A hatpontos modellek pedig a négy- és ötpontos modellek egyesítettje: kettő L és egy $M$ dummy atomot tartalmaznak az oxigén és a két hidrogén mellett.

Minden fent bemutatott modellnek van saját paraméterhalmaza, amelyek különböző problémák vizsgálatára teszik alkalmassá az adott modellt. Általában az oldószer szolgáltatja a legtöbb atomot egy szimulációs rendszerben, ami meghatározó a számítási idő tekintetében. Ennek következtében a három-, ill. négypontos vízmodelleket alkalmazzák a leggyakrabban, amennyiben kellö pontosságot szolgáltat és a vizsgált jelenség ezt lehetővé teszi.

\subsubsection{Termodinamikai sokaságok, hőmérséklet- és nyomáscsatolás}

Az egyes atomok paraméterei, az atomok közötti kölcsönhatást leíró erőtér és az oldószer leírása mellett még szükséges a hőmérséklet- és nyomáscsatolás kezelése is. A hőmérsékletcsatolás általában a sebességek újraskálázásával történik, a nyomás hatásának figyelembe vétele pedig a szimulációs rendszert kijelölő vektorok és az atomi koordináták átskálázásával. A hőmérséklet- és nyomáscsatolásra vonatkozóan sokféle termosztát és barosztát alkalmazható, melyek azonban általában nem variálhatók tetszőlegesen, azaz bizonyos hőmérsékletcsatolási algoritmusok mellett nem választható tetszőleges nyomáscsatolási mód és fordítva. Hasonlóan a fent említettekhez ezen algoritmusok megválasztása is optimalizálási kérdés az elérni kívánt pontosság és a szükséges számítási kapacitások függvényében, természetesen a vizsgálni kívánt rendszer méretének és egyéb sajátságainak figyelembe vétele mellett.

A MD modellrendszereket, illetve sokaságokat több csoportra oszthatjuk. Tekintsünk egy olyan rendszert, amelyben $\mathrm{N}$ darab részecske van, a szimulációs doboz térfogata $\mathrm{V}$ nagyságú és a hőmérséklet pedig $\mathrm{T}$ (és a rendszer kapcsolatban áll egy hőtartállyal), e mennyiségek pedig fixáltak. A statisztikus mechanikában ezt a rendszert egy termosztáttal ellátott NVT sokaságnak nevezzük (más néven kanonikus sokaság). Amennyiben a rendszer nincs kapcsolatban hőtartállyal, azaz a szimuláció során nincs hőmérsékleti csatolás, akkor NVE sokaságokról beszélünk. Ebben az esetben az „E” betű az energia konstans értéken tartását jelöli, azaz kinetikus és a potenciális energia összege állandó, de a nyomás és a hőmérséklet értéke nem szabályozott. Széles körben használt még az NPT sokaság, amelyben a részecskék N száma, a P nyomás és a T hőmérséklet rögzített értékkel bír, illetve ez utóbbi két mennyiség egy barosztát és egy termosztát segítségével szabályozva van, de a szimulált térfogat változhat.

\subsubsection{Szimuláció termosztáttal}

Ha egy rendszer termodinamikailag és mechanikailag elszigetelt, akkor a teljes energia állandó. Viszont bizonyos szimulációkban az energiának vagy a hőmérsékletnek meg kell változnia. Szükséges lehet például a hőmérséklet változtatására, ha fázisátmenetet akarunk tanulmányozni; vagy egy elszigetelt rendszer vizsgálata esetén szükség lehet a kezdeti hőmérséklet kívánt szintre való beállítására. 
A hőmérséklet konstans szinten tartható, ha lehetővé tesszük a vizsgált rendszer számára, hogy hőcserét folytasson egy jelentősen nagyobb rendszerrel, az úgynevezett hőtartállyal vagy termosztáttal. A kisebb rendszer hatása a termosztát hőmérsékletére elhanyagolható, ezért annak hőmérsékletét egy előre megadott konstans értéknek tekinthetjük. Így az idő múlásával a kisebb rendszer felveszi a termosztát hőmérsékletét. Mikroszkopikus szinten a hőcsere a részecskék és a két rendszert elválasztó fal közötti ütközések által megy végbe. Átlagokat tekintve, az elválasztó falakba ütköző részecskék kinetikus energiájának megváltozása a termosztát hőmérsékletétől függ. Az ez által eredményezett veszteség illetve növekedés a kinetikus energiában növeli vagy csökkenti a hömérsékletet, amíg az azonos nem lesz a két rendszerben. Ahhoz, hogy ugyanezt a hatást érjük el a szimulációink során, a vizsgált rendszernek energiát kell nyernie, illetve elvesztenie egy alkalmas módon, amíg a kívánt hőmérsékletet el nem érte, ez az egyensúlyi fázisban történik meg. Kezdetben a részecskék meghatározott kezdeti hellyel és indulási sebességgel rendelkeznek, ezután a rendszer hőmérsékletét beállítjuk egy termosztát segítségével. Miután a kívánt hőmérsékletet elértük, kiszámítjuk a részecskék pályáját és a szükséges mennyiségeket.

Az alábbiakban összefoglaljuk, hogy miképpen lehet egy molekuláris rendszer hőmérsékletét adott értékre beállítani. A rendszer T hőmérsékletét és a kinetikus energiáját az ekvipartíció tétel köti össze:

$$
E_{k i n}=\frac{3 \cdot N}{2} \cdot k_{B} \cdot T
$$

$\mathrm{N}$ jelöli a részecskék számát, a rendszer szabadsági fokainak száma $3 \mathrm{~N}$ (mindhárom térbeli irányra egy) és $k_{\mathrm{B}}$ a Boltzmann-állandó. Tehát a hőmérséklet a következő módon adható meg:

$$
T=\frac{2}{3 \cdot N \cdot k_{B}} \cdot E_{k i n}=\frac{2}{3 \cdot N \cdot k_{B}} \sum_{i=1}^{N} \frac{m_{i}}{2} \cdot v_{i}^{2}
$$

A leggyakrabban használt hőmérséklet-kontrolláló eljárások az Andersen, Brendsen, illetve Nosé és Hoover által kidolgozott termosztátok. Ezen termosztátok mindegyike a sebességek módosításán alapszik, ami vagy explicit módon történik minden részecske sebességének skálázása alapján, (Andersen, Berendsen) vagy implicit módon, amikor is hozzáveszünk a mozgásegyenletekhez egy súrlódási tagot (Nosé-Hoover). Ezek közül a Berendsen-termosztát müködését tekintjük át sematikusan, illetve ennek egy módosított változatát az un. v-rescale eljárást.

A kinetikus energiára vonatkozó fenti összefüggést tekintve nyilvánvaló, hogy a sebesség megszorzása a

$$
\beta=\sqrt{E_{k i n}^{D} / E_{k i n}}=\sqrt{T_{0} / T}
$$


faktorral a rendszer $\mathrm{T}$ hőmérsékletét $T_{0}$-re változtatja. Tehát egy egyszerü lehetőség a hőmérséklet irányítására a következő: minden részecskének a sebességét a választott időpillanatban meg kell szorozni $\beta$-val (ami természetesen maga is időfüggő).

Hogy ezt implementáljuk az aktuális T(t) hőmérsékletet ki kell számolnunk, majd ebből az értékből és az elérni kívánt $T_{0}$ hőmérsékletből megkonstruáljuk $\beta$-t. Az aktuális és az elérni kívánt hőmérsékletek közötti különbségből eredően $\beta$ értéke lehet viszonylag nagy vagy kicsiny, tehát a sebességek skálázása igen jelentősen megváltoztathatja az energiaeloszlást a rendszerben. Ezért a korábban használt $\beta$ helyett gyakran alkalmaznak egy módosított változatot a sebességek skálázására, ami függ egy $\gamma \in[0,1]$ paramétertől:

$$
\beta_{\gamma}=\left(1+\gamma \cdot\left(\frac{T_{0}}{T(t)}-1\right)\right)^{1 / 2}
$$

A $\gamma=1$ választás a korábbi $\beta$ definíciót eredményezi, a $\gamma=0$ esetben pedig a sebesség értékek nem változnak. Ha az integrálási eljárás időközével arányos skálafaktort választunk, $\gamma \sim \delta \cdot t$, akkor a sebességek skálázása minden lépésnél olyan szintü hőmérsékletváltozást eredményez, ami arányos $\mathrm{T}$ és $T_{0}$ különbségével:

$$
\frac{d T(t)}{d t}=\frac{\left(T_{0}-T(t)\right)}{\tau}
$$

Így müködik a Berendsen hőmérsékletcsatolás, azaz egy külső, állandó hőmérsékletü $T_{0}$ hőtartály müködését modellezi, egy $\tau$ csatolási állandó felhasználásával, ami a hőmérséklet különbség gyors, exponenciális lecsengését eredményezi. A v-rescale eljárás lényegét tekintve nem más, mint egy Berendsen termosztát, amely egy sztochasztikus korrekciós tagot is tartalmaz, amely a kinetikus energia korrekt eloszlását biztosítja. Ez azért szükséges, mert habár a Berendsen termosztát gyors algoritmus és sikeresen állít be rendszereket egy adott hőmérsékletre, de a megfelelő kanonikus sokaságok generálására egy hosszabb szimuláció esetén korlátozottan alkalmas. A v-rescale módszer kiküszöböli ezt a hibát és megtartja a Berendsen termosztát gyorsaságát.

\subsubsection{Nyomáscsatolás}

A fenti gondolatmenetnek megfelelően a szimulációs rendszerünkhez csatolhatunk egy „külső nyomás tartályt" is. A leginkább alkalmazott algoritmusok Berendsen, ill. Parrinello és Rahman nevéhez köthetőek. Ennek az egyik oka, hogy ezek az eljárások tetszőlegesen kombinálhatóak a fent említett termosztátok mindegyikével.

A Berendsen barosztát minden nyomáscsatolási lépésben újra skálázza a szimulációs dobozt meghatározó vektorokat (és természetesen ennek megfelelően a többi koordinátát is), ezzel beállítva egy $P_{0}$ nyomás értéket. Az eljárás hasonlít a termosztát esetéhez, a nyomás változás leírható, mint: 


$$
\frac{d P(t)}{d t}=\frac{\left(P_{0}-P(t)\right)}{\tau_{P}}
$$

Ahol a $P_{0}$ referencia nyomás, $\tau_{P}$ pedig a csatolási állandó.

A megfelelő NPT sokaságok generálásához, főképp kisebb rendszerek és termodinamikai mennyiségek számítása (ahol P és V értékek kiemelten fontosak) esetén ajánlott a PerrinelloRahman barosztát alkalmazni. Ez a módszer egyfelől a szimulációs rendszert meghatározó vektorokra vonatkozó differenciálegyenletet használ, ahol is ezen vektorok változása természetesen arányos a $\left(P_{0}-P\right)$ nyomáskülönbséggel. Másfelől viszont az egyes atomok mozgásegyenlete is megváltozik, egy sebességfüggő súrlódási tag hozzávételével, aminek M szorzója a szimulációs doboz vektoraitól függ:

$$
\frac{d^{2} r_{i}}{d t^{2}}=\frac{F_{i}}{m_{i}}-M \cdot \frac{d r_{i}}{d t}
$$

Ahol $r_{i}$ az i-edik atom helykoordinátája, $F_{i}$ a rá ható erő, a tömege pedig $m_{i}$. A ParrinelloRahman módszer egyik hátránya, hogy nem alkalmazható egyensúlytól távoli rendszerek esetén, mert túlontúl nagy vektorváltozásokat, oszcillációkat okoz és nagyobb csatolási állandót kell választani az alkalmazásához. Egy célnyomásra történő beállításra a Berendsen módszer alkalmasabb, megfelelő NPT sokaság generálására pedig a Parrinello-Rahman.

\subsubsection{MD szimulációs protokoll}

A fentiekben áttekintettük a fontosabb MD paramétereket és a főbb alkalmazható eljárások tulajdonságait. Most egy tipikus MD szimulációs protokollt lépéseit vesszük szemügyre.

Miután összeállítottunk egy szimulációs rendszert, azaz a választott programcsomagnak megfelelö formában megadtuk minden atom koordinátáját, ismertek a hozzájuk tartozó paraméterek és az adott feladathoz megfelelő erőteret is kiválasztottuk az első lépés általában egy energiaminimalizáció. Erre azért van szükség, hogy a MD szimuláció indításakor ne jelenjenek meg túl nagy sebességek, megakadályozva a szimuláció lefutását, illetve, hogy nyomás-, vagy hőmérsékletcsatolással kapcsolatos problémák ne lépjenek fel.

Az energiaminimalizáció történhet több lépésben, más-más módszereket alkalmazva és/vagy más-más atomcsoportokra vonatkozó kényszerek mellett. A két legelterjedtebb módszer a steepest descent (SD) és a conjugate gradient (CG). Az előbbi módszer egyensúlytól távoli rendszerekre is alkalmazható, míg az utóbbi nem, viszont a CG módszer az egyensúly közelében jóval hatékonyabb.

Az SD módszer a rendszerben szereplő összes atom koordinátáját változtathatja, de csak meghatározott nagyságú változtatások lehetségesek a koordinátákat illetően. Egy kezdeti maximális elmozdulásnagyságot kell megadni, ami az elmozdulás következtében bekövetkező erőnagyság-változást figyelembe véve skálázódik, ez az érték tipikusan $0,01 \mathrm{~nm}$. Az 
energiaminimalizáció során konvergencia-kritériumokat adunk meg, melyek a rendszerben ható erők nagyságának átlaga, illetve, minden atomot figyelembe véve a maximális erő nagysága. A 7. ábra szemléleti az eljárást. Természetesen nem garantált, hogy első próbálkozásra elérjük a keresett energiaminimumot, ezért mindig alkalmazunk egy maximális lépésszámot, amit ha elérünk, akkor az épp aktuális geometria lesz a számolás kimenete. Általában egy kezdeti SD minimalizáció után a CG módszert alkalmazzuk úgy, hogy annak bementi koordinátái az SD futás kimeneti koordinátái.

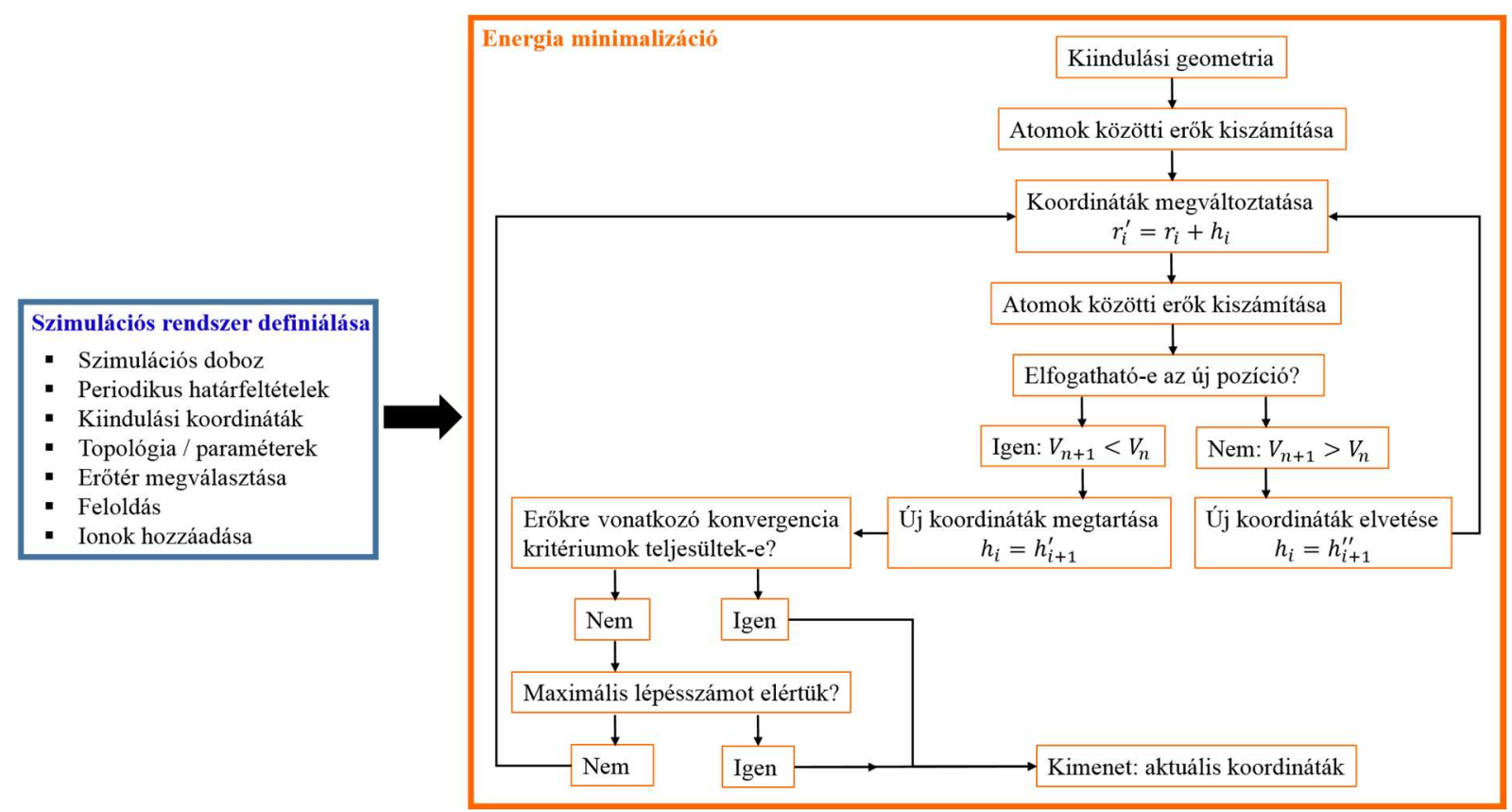

7. ábra Szimulációs rendszer előkészítése, SD energia minimalizáció lépései. A potenciális energiát V jelöli, az atomok pozícióját r, míg az elmozdulásokat h.

Sikeres energiaminimalizáció után lehet elvégezni magát az MD szimulációt, ami a választott csatolásoktól függően NVT, NPT, vagy NVE lehet. A fent említetteken túl a MD szempontjából fontos megválasztandó paraméterek még: szimulációs idő, időbeli lépésköz, adatgyüjtés gyakorisága, kötésekre vonatkozó és egyéb kényszerek stb. A beállításoktól függetlenül az MD számolások egyazon lépéseket követik, melyeket sematikusan a 8. ábra mutat.

A hosszú MD számolások előtt szokás fütési- és egyensúlyi dinamikákat futtatni. Az előbbi lényege, hogy a szimulációs hőmérsékletet egy rövid dinamikában lépésről-lépésre állítjuk be, hagyva időt a rendszerben jelen lévő molekuláknak a reagálásra, ahelyett, hogy a nulladik lépésben egy adott pl. 300 K-es érték mellett generáljuk a (Maxwell-Boltzmann) sebességeloszlást minden atomra. Az egyensúly dinamika is általában egy rövidebb MD számolás, melynek a célja szintén az, hogy a rendszer alkalmazkodhasson az adott oldási- és külső környezethez. Így a kiértékelésre gyüjtött trajektóriák kevésbé valószínű, hogy nem adekvát adatokat fognak tartalmazni, mint pl. nem-egyensúlyi körülményekre vonatkozó értékek. 


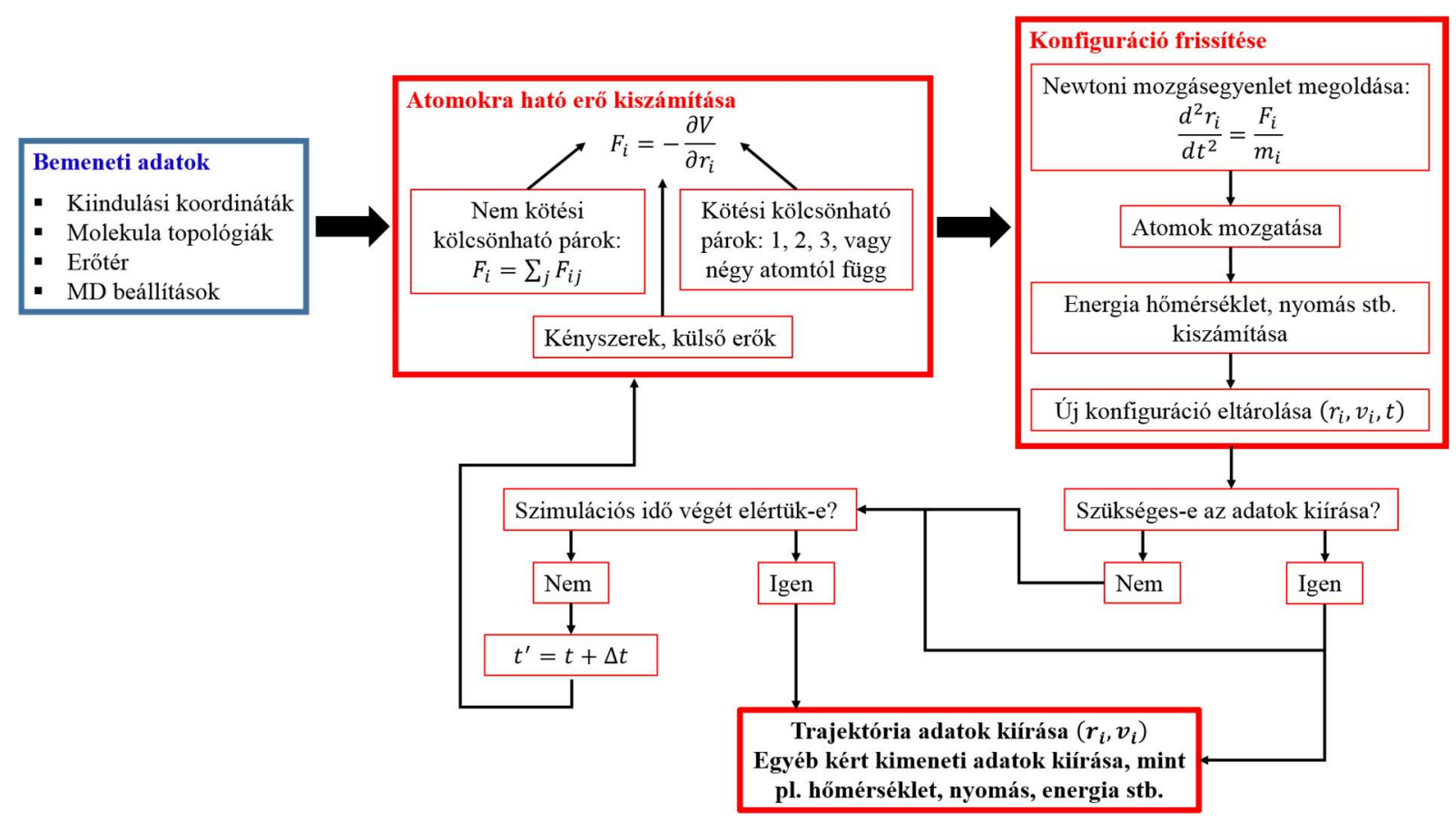

8. ábra Egy MD szimuláció lépései. A potenciális energiát $\mathrm{V}$ jelöli, az atomok pozícióját $\mathrm{r}$, az atomokra ható erőt $\mathrm{F}$, az atomok tömegét $\mathrm{m}$, sebességüket pedig $\mathrm{v}$, az időt pedig $\mathrm{t}$.

\subsubsection{REMD szimuláció}

A REMD (Replica Exchange Molecular Dynamics) módszer [119-121] tulajdonképpen több párhuzamosan, különböző hőmérsékleten futó $\mathrm{MD}$ szimulációt, illetve a különböző hőmérsékleten realizálódó geometriák egymás között időről-időre megkísérelt cseréjét jelenti (9. ábra).

A REMD szimulációk előnye, hogy felgyorsítja a konformációs tér mintavételezését. Ugyanakkor kiküszöbölhető több, az MD számolások során fellépő probléma. Például, ha egy szimulációs rendszer trajektóriája bekerül egy olyan lokális energia minimumba, amely a szimuláció jelentős részében torzítaná a mintavételezést, a REMD számolás során van lehetőség arra, hogy egy magasabb hőmérsékleten kialakult konformációval történő csere által kiszabaduljon ebből az állapotból. Megfordítva, ha egy molekulának olyan konformációs tere van, amelyben a konformációk egy halmazát olyan magas energiagát választja el, hogy azt csak kicsiny valószínűséggel léphető át az adott szimulációs hőmérsékleten, akkor a REMD során fellépő cserék segítségével ezek a konformációk is feltérképezhetővé válnak. Ezzel a módszerrel egy széles hőmérsékleti skálán meghatározható több termodinamikai mennyiség a hőmérséklet függvényében. A módszer legfőbb hátránya pedig az erőforrás-igényesség, hiszen egy $\mathrm{N}$ db hőmérsékleten futó REMD számolás $\mathrm{N}$ db párhuzamos MD számolást követel meg, viszont az egyes szálak ugyanúgy paralelizálhatóak, mint az MD szimulációk esetében. Az MD és REMD módszerek alkalmazásakor ahhoz, hogy kísérleti adatokkal összevethessük a számolási eredményeket a szimulációknak kellő pontosságú egyensúlyi eloszlásokat kell biztosítaniuk. Amennyiben a vizsgált sokaság ergodikus, úgy az időbeli és a sokaságra vonatkozó átlagok felcserélhetőek. Ha ezzel a jellemzővel nem rendelkezik a szimuláció, akkor 
a korrekt sokaságra vonatkozó átlagolás úgy érhető csak el, hogy többször megismételjük a szimulációt, eltérő kezdeti értékekkel (koordináták és sebességek), ami rendkívül forrásigényes lenne számítástechnikai oldalról. Ezért alapvető fontosságú az egyensúlyi állapot mielőbbi elérése és a mintavételezés hatékonysága.

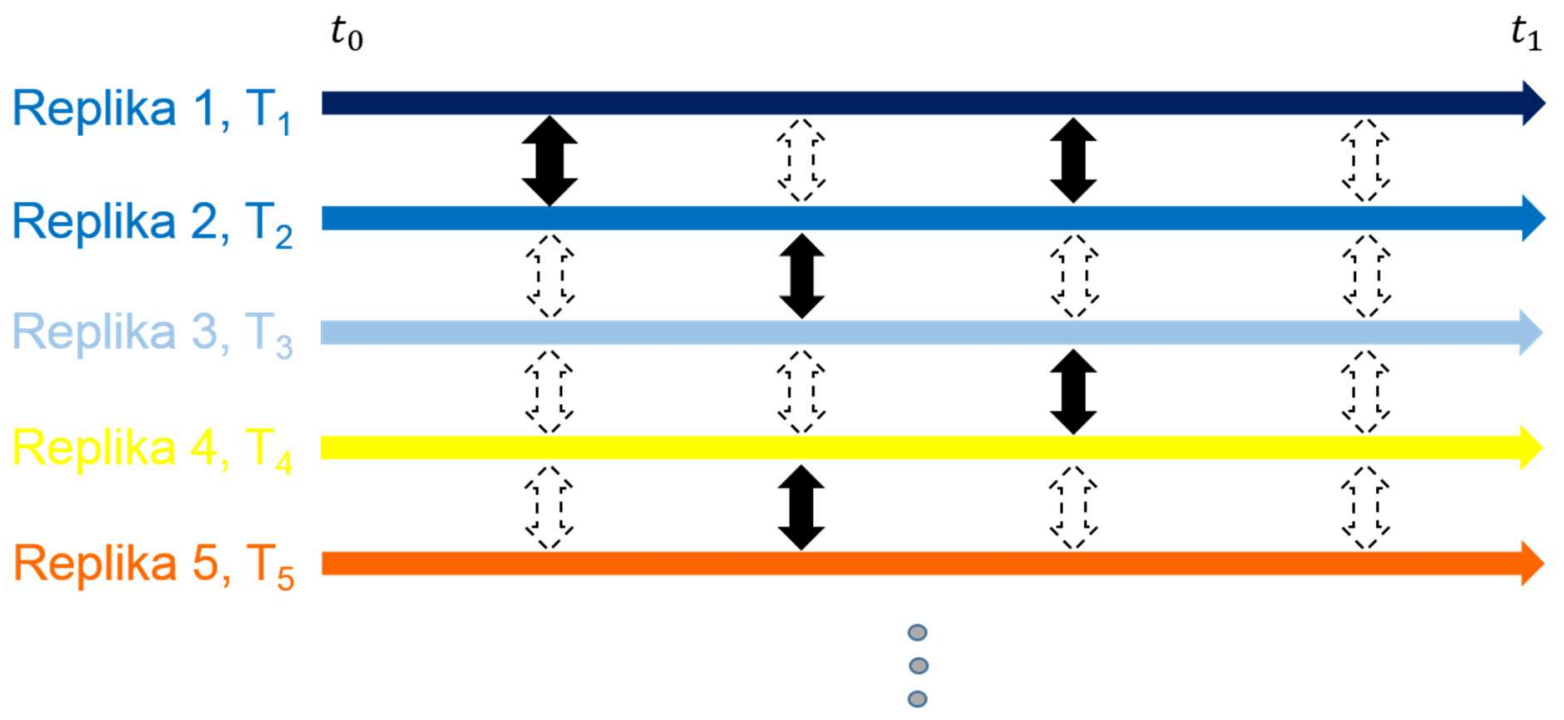

\section{Replika $\mathrm{N}, \mathrm{T}_{\mathrm{N}}$}

9. ábra A REMD szimuláció sematikus ábrázolása. A telt fekete nyilak a sikeres cseréket jelentik a különböző hőmérsékletű replikák között, míg az üresek a sikertelen próbálkozásokat szimbolizálják.

A mintavételezés hatékonyságának növelése a REMD szimulációk esetében úgy történik, hogy a szomszédos MD szálak között rögzített időközönként cseréket kísérel meg a számolás. Ha teljesülnek a feltételek, akkor a különböző hőmérsékleten realizálódott struktúrák „,helyet cserélnek" és az új hőmérsékleteken folytatódik a dinamikájuk. Ennek a cserének természetesen van egy bizonyos valószínüsége, amit 0,2-0,25 között érdemes tartani, és ennek megfelelöen kell generálni az egyes MD szálakhoz tartozó hőmérsékleteket. A csere valószínűsége alapvetően a két szomszédos replika közötti potenciális energia különbségtől függ, illetve az egyes replikákhoz tartozó hőmérsékletektől, az alábbi módon az 1-es és 2-es replika esetében:

$$
P(1 \leftrightarrow 2)=\min \left(1, \exp \left[\left(\frac{1}{k_{B} T_{1}}-\frac{1}{k_{B} T_{2}}\right) \cdot\left(U_{1}-U_{2}\right)\right]\right)
$$

Ahol $k_{B}$ a Boltzmann állandó, U a potenciális energia, T pedig a hőmérséklet. Egy sikeres csere után a sebességek azonnal újraskálázódnak és a következő szimulációs lépésben új kölcsönható atomok keresése történik. 


\subsection{Az MD paraméterek megválasztása, a modellrendszer}

A vizsgálataink során NPT MD és REMD szimulációkat alkalmaztunk. A szimulációk előkészítését, futtatását és részben azok kiértékelését a GROMACS [104] programcsomag segítségével végeztük el. Mindkét típusú számolásban 4,18 nm oldalhosszúságú köbös szimulációs dobozt használtunk, a szimulációs rendszer egy tc $5 \mathrm{~b}$ minifehérjét tartalmazott. A korlátozott méretből adódó felületi hatások kiküszöbölésére periodikus határfeltételt alkalmaztunk. Az alkalmazott vízmodell a TIP3P [113] volt, a rendszerben található vízmolekulák száma megközelítőleg 2200. A szimulációkat elvégeztük mind a kiválasztott Hofmeister-aktív sók jelenlétében, mind azok hiányában. A $\mathrm{NaF}, \mathrm{NaCl}, \mathrm{NaClO}_{4}, \mathrm{NaNO}_{3}$ sókat külön-külön, 1 mólos koncentrációban adtuk hozzá a tiszta vizes modellrendszerhez. $\mathrm{A} \mathrm{Na}^{+}, \mathrm{F}^{-}$ és $\mathrm{Cl}^{-}$ionok esetén Joung és mtsi. paramétereit [122], a $\mathrm{ClO}_{4}{ }^{-}$és $\mathrm{NO}_{3}{ }^{-}$ionok esetén pedig Baaden és mtsi. paramétereit használtuk [123].

A két szimulációs csoport esetén az első lépés az energiaminimalizáció volt, egy 10.000 lépéses steepest descent eljárás segítségével. Ezt pedig egy rövid, 10 ns hosszúságú egyensúlyi NPT dinamika követte, minden vizsgált rendszer esetén az aktuális hőmérsékleteken. Ennek a protokollnak a kimeneti szerkezeteiböl indul a kiértékelésre használt trajektória adatok számolása.

Az NPT számolások során a tc5b minifehérjét egy harmonikus kényszer segítségével rögzített szerkezetben tartottuk, a kényszer erőállandója: $10^{3} \mathrm{~kJ} \mathrm{~mol}^{-1} \mathrm{~nm}^{-2}$. A választott erőtér az Amber ff99SB-ILDN [124] volt, a szimulációs hőmérséklet pedig $300 \mathrm{~K}$. A szimulációs időt $100 \mathrm{~ns}$ hosszúságúnak választottuk, míg az integrálási lépésköz 1 fs volt. A hőmérsékletcsatolást a vrescale eljárás [125] segítségével végeztük, a nyomáscsatolásért pedig a Parrinello-Rahman barosztát [126] felelt, rendre 0,1 és 0,5 csatolási állandókkal. Továbbá a H atomokat tartalmazó kovalens kötésekre a LINCS algoritmust alkalmazva [127] kényszerek vonatkoztak, melyek a dinamika stabil futását segítették elő. Az elektrosztatikát 1,0 nm-es lecsengési távolsággal kezeltük és a PME eljárást használtuk, a kölcsönható atompárok keresése minden tizedik lépésben történt.

A REMD szimulációk 32 hőmérsékleten készültek egy 300-450 K fokos hőmérsékleti sávban, a szimulációs idő 600 ns volt. A szimulációs hőmérsékletek generálása egy webserver [128] segítségével történt, ami kifejezetten a GROMACS programcsomagra és all-atom eröterekre tekintettel dolgozik. A releváns MD paraméterek identikusok voltak az NPT-nél használtakkal, azonban a minifehérjére nem vonatkozott most harmonikus kényszer. A replikák közötti cserére minden kétezredik integrálási lépésben történt kísérlet (2 ps-onként). A kiértékelés során csak a 300-360 K hőmérsékleti sávba tartozó trajektóriák utolsó 300 ns-os részét használtuk.

A fentiek mellett szimulációk egy harmadik csoportját is elvégeztük. Ezek szintén NPT számolások voltak, de csak vízmolekulákat és a kiválasztott sókat tartalmazták 1 mólos koncentrációban. A releváns MD paraméterek megegyeztek a tc $5 b$ molekulát is tartalmazó NPT számolásoknál alkalmazottakkal. Ezen számolások célja az ionok oldódási sajátságaiknak és az első-, ill. a második oldódási burkukban lévő vízmolekulák tulajdonságainak a vizsgálata volt. 


\subsection{A molekuladinamikai szimulációk kiértékelése}

A kiértékelések során vagy a GROMACS programcsomagba beépített programokat, illetve általunk írt szkripteket és programokat használtunk.

\subsubsection{Határfelületi feszültség kiszámítása}

A határfelületi feszültség koncepcióban alkalmazott határfelületi szabadenergia (4) egyenlet szerinti összefüggésére alkalmazható a statisztikus fizikában ismert Lineáris válasz elmélet (Linear Response Theory, LRT) [129]. Lineáris összefüggést feltételezve A és G között és feltéve, hogy $\mathrm{G}_{0}$ konstans a következö összefüggés igaz:

$$
\frac{\partial \bar{A}}{\partial \gamma}=-\beta \cdot \overline{\Delta A^{2}}
$$

Ahol $\bar{A}$ és $\overline{\Delta A^{2}}$ rendre a SASA átlaga és szórásnégyzete. Továbbá $\beta=\left(k_{B} \cdot T\right)^{-1}$, ahol $k_{B}$ a Boltzmann-állandó, T pedig az abszolút hőmérséklet. Ebből pedig a sók által kiváltott felületi feszültség változásra a következő numerikus integrálással számolható egyenlet nyerhető:

$$
\Delta \gamma_{s o ́-v i ́ z}=-\int_{\bar{A}_{v i ́ z}}^{\bar{A}_{s o ́}} \frac{1}{\beta \overline{\Delta A^{2}}} d \bar{A}
$$

Ahol az alsó indexekben szereplő „víz” a referenciaként használt tiszta vizes rendszert jelenti, míg „só” egy Hofmeister-aktív sót tartalmazó rendszert.

\subsubsection{Radiális eloszlás, felületszámolás}

Az RDF és a SASA számolások a GROMACS beépített programjai segítségével történtek. A SASA számolás algoritmusát Scharf és mtsi. [130] munkái alapján implementálták. Ez az algoritmus hasonló módon számítja a felület értékeket, mint ahogy Shrake és Rupley elöször kidolgozták a módszert [45], azonban kevesebb számítási igénnyel rendelkezik. A módszer lényege hogy a molekulában található minden egyes atom van der Waals sugarai által meghatározott felszín fölé ekvidisztáns módon egy pont hálót határozunk meg, amiből a SASA értékét számoljuk. A távolság, amit az egyes atomok körüli pont háló meghatározásához használunk az egy „,vízmolekulát” tartalmazó gömb becsült sugara. Ez lényegében megfelel egy gömb „végiggörgetéséhez” a van der Waals felületen. A pontosság természetesen függ mind a van der Waals sugarak értékétől, mind a becsült vízmolekula-sugártól; ez utóbbit általában 1,4 Å-nek választják. A kiértékelő program kimenete az adott atomcsoporthoz tartozó teljes SASA érték az idő függvényében, illetve külön-külön hidrofób és hidrofil felületek változása. 
Az RDF egy távolságtól függő $g_{A B}(r)$ párkorrelációs függvény egy rögzített $\mathrm{A}$ és $\mathrm{B}$ atomcsoport között:

$$
g_{A B}(r)=\frac{\left\langle\rho_{B}(r)\right\rangle}{\left\langle\rho_{B}\right\rangle}
$$

Ahol $\left\langle\rho_{B}(r)\right\rangle$ a B atomok számsürüsége az $\mathrm{A}$ atomcsoporttól $\mathrm{r}$ távolságban lévő dr vastagságú gömbhéjban és $\left\langle\rho_{B}\right\rangle$ pedig az átlagos számsürüség a $B$ csoportban lévő atomoknak az összes lehetséges gömbhéjra. A számolás során egy $\mathrm{r}_{\max }$ értékig történik a gömbhéjak kijelölése, ami egy köbös szimulációs dobozban alapbeállításon az oldalhossz fele, a dr pedig 0,002 nm. A sürüségeket az összes szimulációs lépésben kiszámoljuk és időbeli átlagot képzünk belöle, erre utal a 〈 〉 jelölés. Ez a módszer kiváltképp arra használatos, hogy azonosítsunk olyan régiókat, ahol az egyik atomcsoport nagyobb számban van jelen az egyéb térfogatokhoz képest. Amennyiben vannak ilyen kitüntetett térrészek, akkor azokban a távolságokban az RDF-nek maximuma van, amit általában egy minimum érték követ, elválasztva ezzel az adott kitüntetett régiót a többitől, vagy ha nincs több maximum, akkor onnantól a függvény egyenletesen tart a nagy távolságokban jellemző (tömbfázisbeli) értékhez.

\subsubsection{DDCI görbék, minimális távolság}

Ahogy a fenti definícióból is látszik, az RDF alkalmas eszköz oldódási sajátságok vizsgálatára (pl. vízmolekulák száma egy adott régióban, ezek átlagos orientációja), vagy ionfölhalmozódás töltött csoportok közeli feltérképezésére. Másfelől, makromolekulák esetében (melyek alacsonyabb szimmetriával rendelkeznek a kisebb szerves molekulákkal összehasonlítva), az RDF-ek egy finomított változata az un. proximális p-RDF függvények [131, 132] az inkább adekvát eszközök, melyek pontosabb térfogatszámolással működnek. Mindazonáltal bármilyen RDF alapú megközelítéshez a normáláshoz egy kellően sürü grid beosztás melletti térfogatszámolás szükséges és az ehhez kapcsolódó hibák nem kiküszöbölhetőek. Például a mioglobin esetében p-RDF alkalmazása mellett is jelentős hibák merültek fel a molekula körüli oldószer sürüségének számolásában [133]. Az RDF-ek értelmezése olyan régiókra koncentrál, amelyek minimumokkal vannak egymástól elválasztva. Amennyiben két atomcsoport közötti kölcsönhatást vizsgálunk ezek a minimummal elválasztott régiók nem kötődnek közvetlenül az egyes típusú kölcsönhatások megvalósulási valószínüségéhez, ha RDF-et, vagy p-RDF-et alkalmazunk. Ezen megközelítések mellett egy egyszerübb leíró eszközt is használtunk, ami közvetlen információt szolgáltat az ionok és fehérje egyes részei közötti párformálódási tulajdonságokról: a legközelebbi ionok távolság eloszlását (DDCI görbék). Hasonló módszert használtak Friedman és mtsi. [134] ion-aminosav kölcsönhatások feltérképezésére egy kisebb globuláris fehérje esetében. A DDCI (Distance Distribution of Closest Ions) görbék számolása során az első lépés a kérdéses atomcsoportok közötti összes lehetséges távolság meghatározása, majd a minimális érték kiválasztása, amit a szimuláció minden időpontjában megteszünk (10. ábra). 


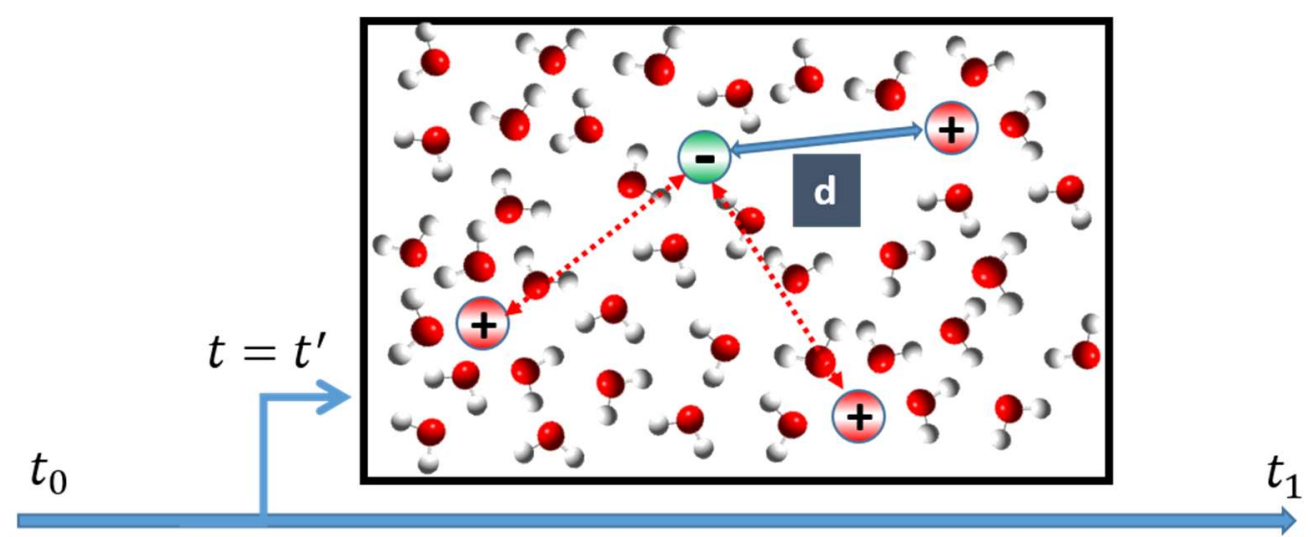

MD trajektória

10. ábra A DDCI görbékhez szükséges minimális távolságok számolása. A negatív töltéscsoporthoz csak a legközelebbi kék vonallal jelölt d távolságot vesszük figyelembe, a minimum keresést minden $t$ időpontban elvégezzük.

Ezt követően egy $d r=0,01 \mathrm{~nm}$-es beosztás mellett az egyes távolságértékekhez $(r+d r)$ tartozó relatív gyakoriságokat határozzuk meg, majd a szimulációs idővel normálva egy valószínűségi eloszlást kapunk.

Azaz annak a valószínüsége, hogy egy adott $r$ távolságban lévő $d r$ vastagságú térrészben van a legközelebbi kölcsönható atom a vizsgált atomcsoporttól $P(r<\xi<r+d r)$, ahol $\xi$ egy folytonos eloszlású valószínűségi változó és a két atomcsoport közötti minimális távolságot jelenti.

A DDCI görbék segítségével közvetlen információ nyerhető a két atomcsoport közötti elönyben részesített kölcsönhatástípust illetően. Ezek az atomcsoportok lehetnek csak ionok, vagy ionok és egy fehérje kiválasztott kölcsönhatási helyei. Csak a legközelebbi atomot, vagy iont vesszük csak figyelembe a DDCI görbék számolása során, ami viszont szavatolja, hogy minden kölcsönhatási hely esetében mindig csak a legerősebben kölcsönható atomot / iont vizsgáljuk. Ez a tulajdonság nem áll fent az RDF-ek esetén, mivel ez a módszer több iont is számításba vehet. Így egy vízmolekulák által közvetített kölcsönhatás jelenléte nem zárja ki az ezzel párhuzamosan fellépő közvetlen kölcsönhatás megvalósulást az RDF alapú megközelítéseket alkalmazva, ugyanakkor a DDCI görbék esetében ez a probléma nem jelentkezik. A DDCI görbék kiszámíthatóak több atomból álló ion csapdákra, csak egy töltött csoportra, vagy akár az egész fehérje felszínre. Ezt a leíró mennyiséget használva természetes módon, egyszerre azonosítható a közvetlen- és vízmolekulák által közvetített kölcsönhatások preferáltsága. Ez a mennyiség alkalmas a korábban bevezetett ion-ion kölcsönhatás típusok azonosítására is (CP, SSP, 2SP). Ha egy DDCI görbének csak egy csúcsa van egy megfelelően kicsiny távolságban, akkor a két vizsgált elem párt formál, azaz közvetlen CP típusú kölcsönhatásba lépnek egymással. Több maximum jelenléte azt jelzi, hogy vízmolekulák által közvetített kölcsönhatások is fellépnek. Amennyiben csak egy vízmolekula van a kölcsönható atomok / atomcsoportok között, akkor SSP típusú a kölcsönhatás, ha két vízmolekula, akkor pedig 2SP típusú [135]. 


\subsubsection{Orientációs autokorrelációs függvények}

Az orientációs autokorrelációs függvény egy vízmolekula esetén a következő:

$$
C_{N}(t)=\lim _{T \rightarrow \infty} \frac{1}{T} \int_{0}^{T} P_{N}(\bar{u}(\tau) \cdot \bar{u}(\tau+t)) d \tau
$$

Ahol $\mathrm{P}_{\mathrm{N}} \mathrm{N}$-edrendü Legendre polinom, $\bar{u}$ pedig egy a vízmolekula szerkezetéhez rögzített egységvektor, mint például a vízmolekula síkjára merőleges, vagy az oxigén és egy hidrogén atom közötti egységvektor. Ennek a mennyiségnek az előnye, hogy nem függ a vízmolekulák számától, így a vizsgált régiókban található összes vízmolekulára ki lehet átlagolni. A számolásaink során minden vizsgált esetben 500 egymástól független autokorrelációs függvényt átlagoltunk össze egyenletes elosztás mellett 20 ps hosszúságú MD trajektória szakaszokat felhasználva. Annak érdekében, hogy a kísérleti (IR spektroszkópiai) eredményekkel összevethetőek legyenek az adatok $\mathrm{N}=2$ (azaz $\left.C_{2}(t)\right)$ választással éltünk. 


\section{Eredmények}

\subsection{Oldószer számára hozzáférhető felület [P1]}

A felületi feszültség változások kiszámításához a 600 ns hosszúságú, 32 szálas, 300-450 K hőmérsékleti sávban végzett REMD szimulációinkat használtuk fel. Ezek a szimulációk két csoportra bonthatók, az egyikben csak vízmolekulákat, semlegességet biztosító ellenionokat és a tc5b minifehérjét tartalmazott a modell rendszer, ez referenciaként szolgált. A számolások másik csoportjában a választott Hofmesiter-aktív ionok nátrium sói 1 mólos koncentrációban voltak jelen. A kozmotróp és kaotróp ionok befolyásolják a globuláris fehérjék térbeli stabilitásában kulcsszerepet játszó hidrofób kölcsönhatásokat, ezért a fehérje állapotát leíró mennyiségnek az átlagos oldószer számára hozzáférhető felületet (SASA) választottuk. Ahogyan a 11.A ábrán látható a vizsgált ionok a HS-ban elfoglalt helyzetüknek megfelelően változtatták meg a SASA értékét. A kaotróp $\mathrm{ClO}_{4}{ }^{-}$és $\mathrm{NO}_{3}{ }^{-}$anionok jelenlétében ez a felület a tiszta vizes esethez viszonyítva megközelítöleg, rendre 1,5 és $1 \mathrm{~nm}^{2}$-rel növekedett $300 \mathrm{~K}$-en, a nyitottabb térszerkezetek irányába tolva el a konformációs sokaságot. A Hofmeister-semleges $\mathrm{NaCl}$ só hozzáadása kis mértékben növelte az átlagos SASA-t, enyhén kaotróp jellemzőket mutatva, míg a $\mathrm{F}^{-}$ion jelenlétében az átlagos SASA megközelítöleg $0,2 \mathrm{~nm}^{2}$-rel csökkent. A SASA értékek átlagos fluktuációit (RMS) mutatja a 11.B ábra, mely egy széles hőmérsékleti sávban (megközelítőleg 300-345 K között) hasonló jellemzőkkel rendelkezik, mint a SASA átlag, nevezetesen a fluktuációk nagyobbak a kaotróp ionok jelenlétében, viszont mérsékeltebbek a kozmotróp anion esetében a tiszta vizes rendszerhez viszonyítva.
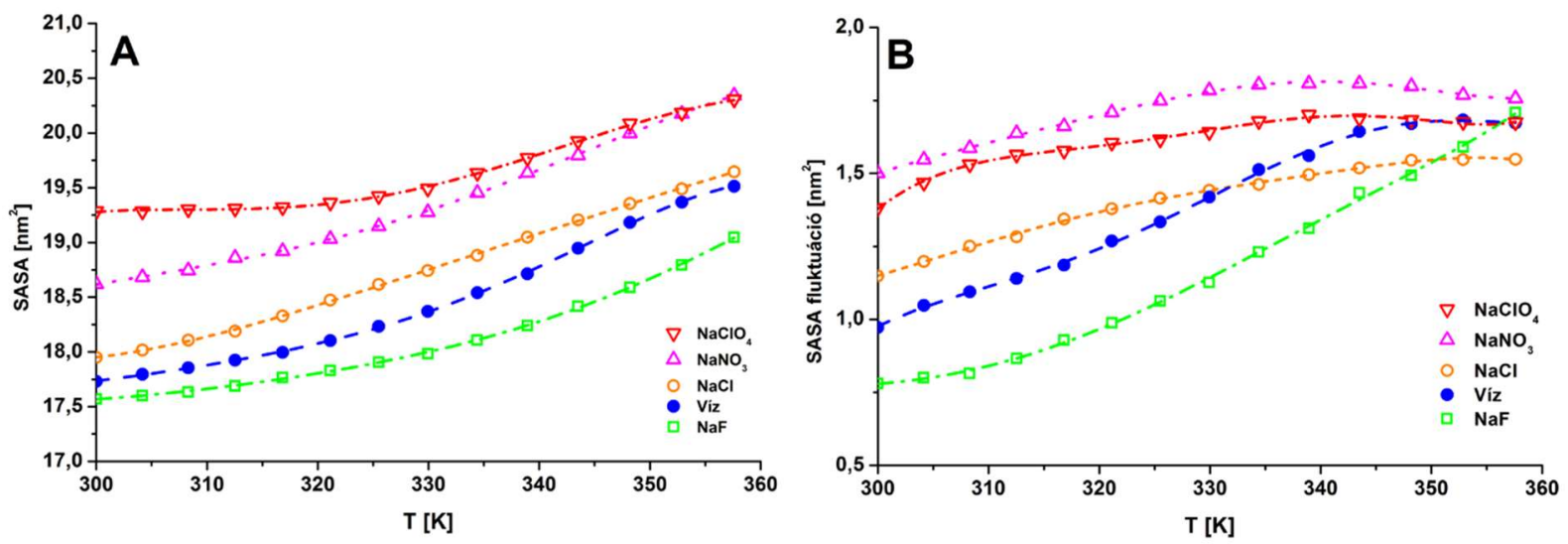

11. ábra A SASA átlaga (A) és fluktuációja (B) a hőmérséklet függvényében az összes vizsgált rendszer esetében.

Az átlagos SASA értéket tekintve minden ion a HS-ban elfoglalt pozíciójának megfelelően változtatta meg az adott hőmérséklethez tartozó konformációs sokaságot, azaz a kaotróp hatású sók a „nyitottabb” szerkezetek felé tolták el a sokaságot, míg a kozmotróp NaF só hatása ellentétes volt.

Hasonló szerkezeti „fellazulás” volt megfigyelhető a bakteriorodopszin esetében is, kaotróp oldási környezetben [19]. Nemrégiben Tadeo és mtsi. a Streptoccocus Magnus immunglobulinjának L fehérjéjét (G kötési doménjét) választva modellrendszernek vizsgálták 
a Hofmeister-aktív anionoknak a fehérjeszerkezet stabilitására gyakorolt hatását, CD és fluoreszcens spektroszkópiai módszereket használva [4]. Ez a rendszer számos hasonlóságot mutat a tc5b-vel (bár valamivel nagyobb, 62 aminosavból épül fel): stabil másodlagos-, és harmadlagos szerkezettel rendelkezik, a másodlagos szerkezeti elemek között található $\alpha$-hélix és különféle $\beta$ szerkezetek. Továbbá, a hidrofób kölcsönhatások fontos szerepet játszanak a szerkezet stabilitásában. Tadeo és mtsi. lizin és glutamin mutációkat alkalmazva megváltoztattak különböző apoláros felületelemeket a fehérje felszínén. Minden vizsgált módosítás esetén azt találták, hogy a kozmotróp $\mathrm{F}^{-}$ion stabilizálja az adott szerkezetet, míg a $\mathrm{NO}_{3}{ }^{-}$és $\mathrm{ClO}_{4}^{-}$kaotróp anionok pedig ellentétes hatást fejtenek ki az összes vizsgált koncentrációban (0,1-1,0 M). Ezek a megállapítások alátámasztják a REMD szimulációkból számolt SASA-változások megalapozottságát. Emellett az eredmények teljesen konzisztensek a Dér és mtsi. által javasolt határfelületi feszültség koncepcióval [20, 21], és a felületi feszültség értékeket szimulációs eszközökkel sikerült származtatnunk.

\subsection{Határfelületi feszültség [P1]}

A 11. ábrán bemutatott eredmények felhasználásával és egy egyszerü numerikus integrálás segítségével kiszámítható a vizsgált ionok által indukált felületi feszültség változás a tiszta vizes esethez képest $\left(\Delta \gamma_{s o ́}-v i ́ z\right)$. Ahogy a 12. ábrán látható, $300 \mathrm{~K}$-en a kaotróp $\mathrm{ClO}_{4}{ }^{-}$és $\mathrm{NO}_{3}{ }^{-}$anionok csökkentették a felületi feszültséget rendre 5,2 és $2,7 \mathrm{mN} / \mathrm{m}$-rel. Ugyanakkor a $\mathrm{Cl}^{-}$ionok csökkentették, míg a $\mathrm{F}^{-}$ionok növelték $\gamma$ értékét megközelítőleg $1 \mathrm{mN} / \mathrm{m}$-rel.

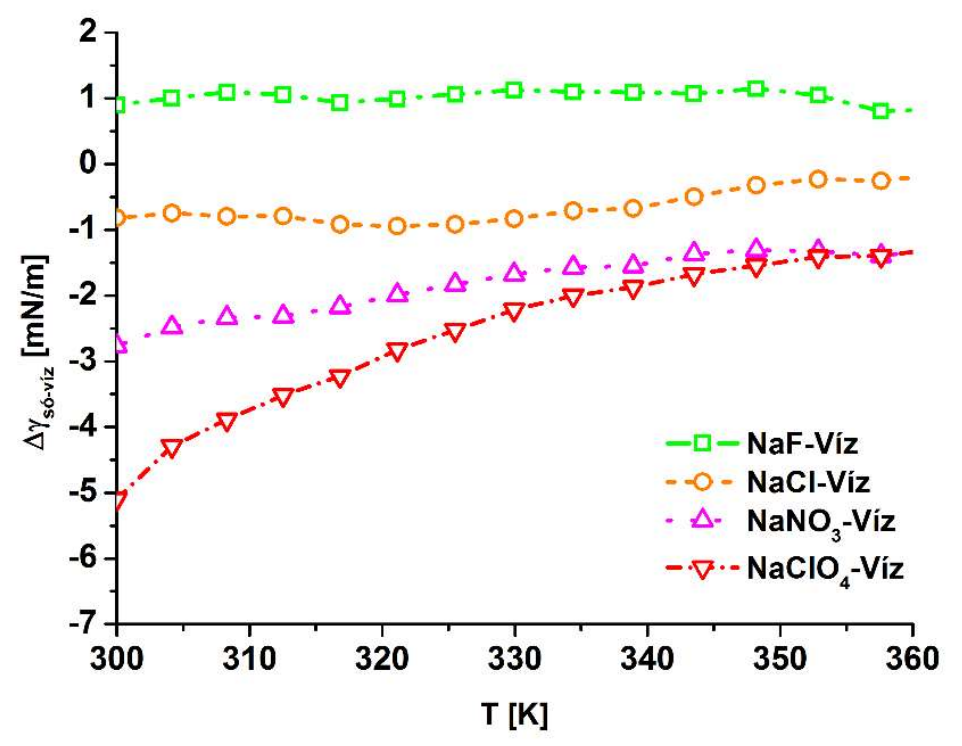

12. ábra $\mathrm{A} \mathrm{NaF}, \mathrm{NaCl}, \mathrm{NaNO}_{3}$ és $\mathrm{NaClO}_{4}$ sók által kiváltott Felületi feszültség változások a tc5b minifehérje-víz határfelületen a tiszta vizes esethez viszonyítva.

A nagyobb hőmérsékleti értékekhez közelítve a $\Delta \gamma_{s o ́-v i ́ z}$ értéke csökken, mivel a megnövelt hőmérséklet hatására a tiszta vizes esetben is destabilizálódik a tc5b kompakt szerkezete és az oldatban jelenlévő ionok hatására létrejövő SASA-fluktuációk marginálissá válnak a 
hőmérséklet hatásához képest. A felületi feszültség változások a 300-360 K hőmérsékleti intervallumban HS szerinti rendezettséget mutatnak. A határfelületi feszültség koncepció előrejelzéseinek megfelelön a kaotróp ionok csökkentik, míg a kozmotróp ionok növelik $\Delta \gamma$ értékét a tiszta vizes esethez viszonyítva.

A tc5b-t érintő számolások mellett végeztünk szimulációkat az Alzheimer-kórban kulcsszerepet játszó amiloid $\beta_{1-42}$ szakaszára tiszta vizes esetben, illetve $\mathrm{NaF}$ és $\mathrm{NaClO}_{4}$ sók jelenlétében. Ugyanezeket a sókat használva számolásaink egy másik csoportja a FAD (flavin-adenindinukleotid) molekulára irányult [136], mely egy elektronátvivő kofaktor. Az amiloid $\beta_{1-42} \mathrm{a}$ tc5b-nél jelentősen nagyobb nem globuláris fehérje, a FAD molekula pedig egy mindösszesen 86 atomból álló két gyürüt tartalmazó, a tc5b-nél jelentősen kisebb rendszer. Mindezek ellenére mind a két esetben a SASA-számolásokat és a $\Delta \gamma$ (21) összefüggés szerint meghatározását elvégezve a tc5b-nél látottakkal teljesen konzisztens eredményeket kaptunk. Azaz a kaotróp anionok megnövelték az átlagos SASA-t és annak fluktuációját is, negatív $\gamma$ változást okozva, míg a kozmotrópok jelenlétében a hatás ellentétes volt.

\subsection{Szabadenergia profil [P2]}

Az oldott ionok által kiváltott fehérje-víz határfelületi feszültség változások meghatározása mellett a határfelületi feszültség koncepció szempontjából fontos kérdés még a koncepcióban feltevésként használt U-alakú szabadenergia profil (2. ábra) létezése. Felhasználva a REMD szimulációk szolgáltatta sokaságokat egy $\Delta G_{\text {határfelületi }}$ eloszlás származtatható a teljes konformációs térre, az egyes állapotok megvalósulását leíró valószínűségi eloszlás segítségével az alábbi módon:

$$
\Delta G(R)=-k_{B} \cdot T \cdot \ln (P(R))
$$

Ahol $\mathrm{R}$ a konformációs tér egy pontja, $P(R)$ az ehhez az állapothoz tartozó megvalósulási valószínüség, $k_{B}$ a Boltzmann-állandó, T pedig az abszolút hőmérséklet. Mivel a konformációs tér általában csak sok változóval írható le, gyakran csak egy, vagy két mennyiséget használnak fel a szabadenergia-profil meghatározására. Ezt a módszert követve a SASA mennyiséget választottuk a minifehérje állapotát leíró mennyiségnek a fö reakciókoordináta mentén (a feltekeredett állapotból a szétesett állapotba vezetve). A tiszta vizes esetet tekintve egy szigmoid-illesztés segítségével meghatároztuk az átmeneti hőmérsékletet, ami 340,47 K-nek adódott. A számoláshoz az átlagos helicitás értékét választottuk leíró mennyiségnek. Ezeket a görbéket és a származtatott átmeneti hőmérsékleteket minden vizsgált rendszer esetén a 13. ábra mutatja. A tiszta vizes rendszerhez tartozó átmeneti hőmérséklet a kísérleti értékek felett van [28, 80], azonban az eltérés nem annyira jelentős, mint egyéb szimulációs munkákban, amelyek között előfordul $440 \mathrm{~K}$-es érték is $[31,75]$. A pontatlanság valószínűleg alapvetően a klasszikus erőtér által szabott korlátok következménye, továbbá a polarizáció hiányából eredeztethetö. 


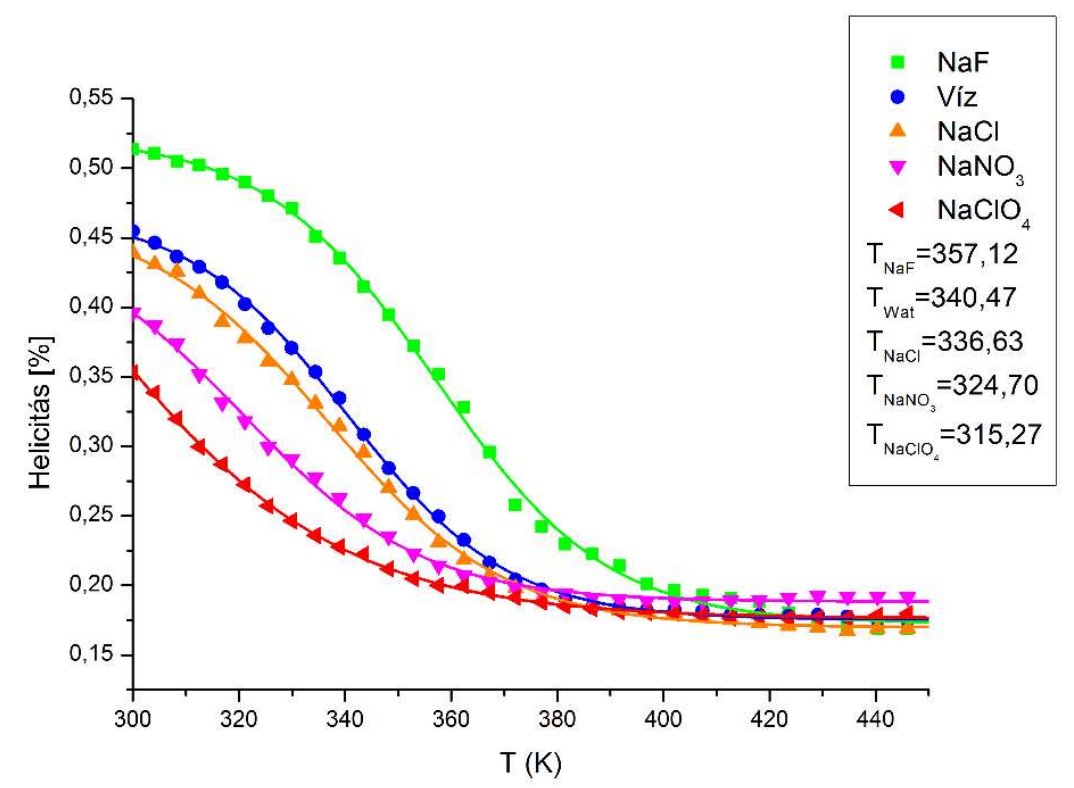

13. ábra Az átlagos helicitások hőmérséklet függése és a származtatott átmeneti hőmérsékletek értéke a Hofmeister-aktív ionok jelenlétében és azok hiányában.

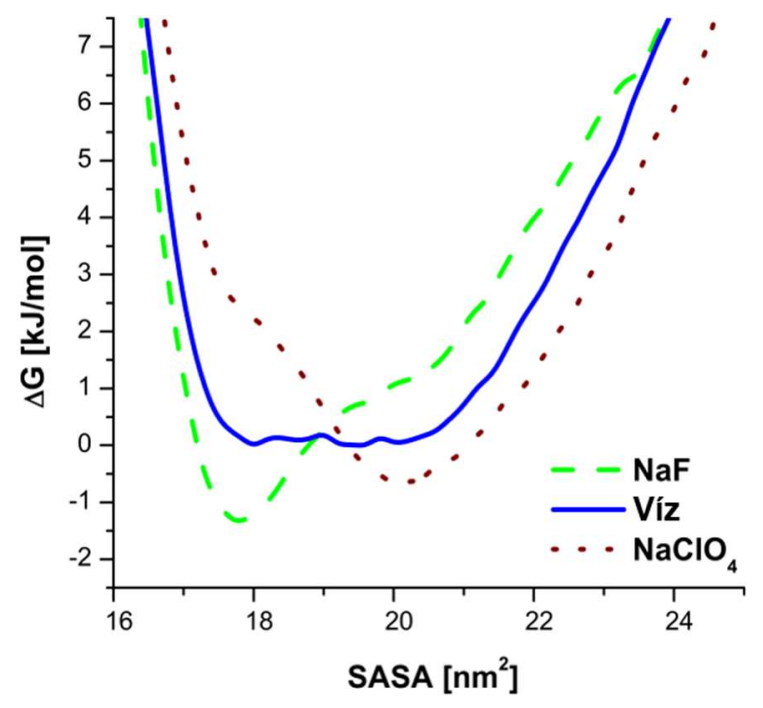

14. ábra A tc5b minifehérje szabadenergia-profilja a tiszta vizes és a $\mathrm{NaF}, \mathrm{NaClO}_{4}$ sókat tartalmazó esetben a 340,47 K hömérséklethez legközelebb eső sokaságokban számolva.

Az átláthatóság érdekében csak a tiszta vizes rendszer esetén, továbbá a leginkább kozmotróp és kaotróp anion jelenlétében tekintjük át az eredményeket.

A tiszta vizes eset átmeneti hőmérsékletéhez tartozó szerkezeti sokaságokat használva meghatároztuk a szabadenergia-profilokat a tiszta vizes, továbbá a $\mathrm{NaClO}_{4}$ és $\mathrm{NaF}$ sókat tartalmazó rendszerekre. Ahogy a 14. ábrán látható a tiszta vizes esetben az energiaprofil megközelítőleg U-alakú és közel állandó értékekkel rendelkezik a 17,5-21 nm² intervallumban, a görbe „alsó részén”. Ugyanakkor a kozmotróp anion jelenléte egy pozitív meredekségü lineáris tagot ad hozzá az alapvonalhoz, a kaotróp anion esetében pedig a meredekség negatív. 
Vagyis a határfelületi feszültség koncepció feltevéseinek megfelelően egy megközelítőleg lineáris tag azonosítható a $\Delta G$ SASA-tól való függését tekintve, (4)-nek megfelelően
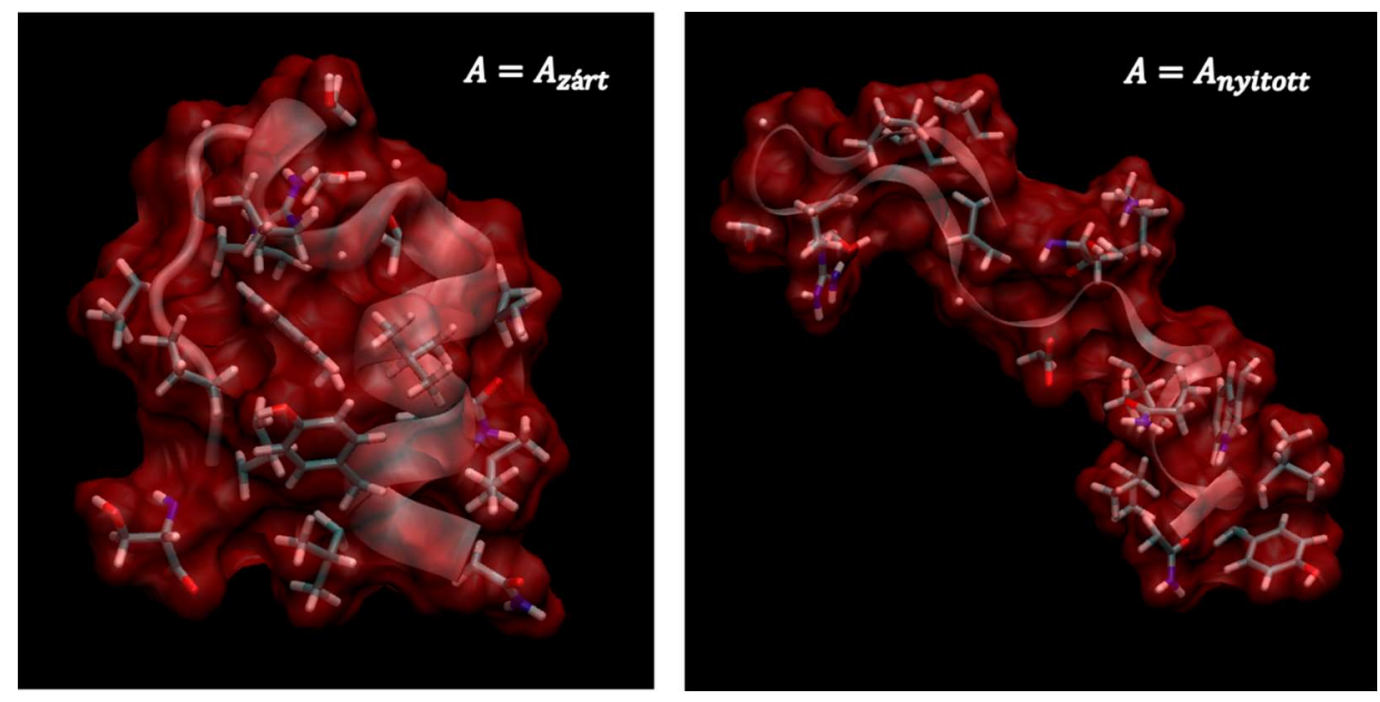

15. ábra A tc5b minifehérje egy „zárt” és egy „nyitott” szerkezete, a képek a tiszta vizes REMD szimuláció konformációs sokaságaiból származnak.

A $\mathrm{F}^{-}$ionok jelenléte a „zártabb” konformációk irányába tolja el a szerkezeti sokaság összetételét, míg a $\mathrm{ClO}_{4}{ }^{-}$ionok jelenlétében a „nyitottabb” konformációk a preferáltabbak ezen a hömérsékleten. A 15. ábra szemlélteti a tc $5 \mathrm{~b}$ minifehérje egy ,zárt” és egy „nyitott” konformációját és a hozzá tartozó SASA-t (azaz a 2. ábrán látható $A_{1}$ és $A_{2}$ határokhoz közeli állapotokat). A szabadenergia-profil számolások kvalitatív természetük ellenére erős támogatást jelentenek a határfelületi feszültség koncepciónak, ami alapvetően a fehérje-víz határfelületen fellépő felületi feszültség változás központi szerepét hangsúlyozza a fehérjékhez köthető HE-ban.

Megjegyzendő még, hogy a felületi feszültség értékek származtatásához használt SASA értékek számolása elvégezhető nemcsak a teljes felület esetében, hanem külön-kölün a hidrofób és hidrofil komponensekre is. Ezek a számolások mindkét esetben hasonló karakterisztikájú görbéket eredményeznek az átlag és szórás tekintetében, mint a teljes SASA esetén bemutatottak (11. ábra). Továbbá, az eloszlásukat vizsgálva szintén a teljes SASA adataiból származtatottakhoz hasonló U-alakú szabadenergia-profilokat szolgáltatnak. Mindezek azt mutatják, hogy a határfelületi feszültség koncepció feltételezései a $G_{0}$-t és a (4) egyenletet illetően megállnak a tc5b minifehérje esetében.

\subsection{Fehérje-víz határfelület jellemzői}

Az előző szekcióban kimutatott Hofmeister-aktív sók által kiváltott SASA- és $\gamma$-változások nem adnak információt a kapcsolódó mikroszkopikus szintű mechanizmusokról. A vizsgált ionok esetén tapasztalt felhalmozódási különbségeknek és a határfelületen található vízmolekulák szerkezeti változásainak fontos szerepük van az előző szekcióban tárgyalt felületi feszültség változások létrejöttében [20, 57-59, 137]. Annak érdekében, hogy megérthessük, hogy pontosan 
hogyan magyarázható ez jelenség atomi szinten a fehérje-víz határfelületi réteg részletes feltérképezése szükséges. A $\gamma$-értékek megváltozása alapvetően a fehérje és az oldási környezete közötti kapcsolat módosulásából eredeztethető. Az ionok hatását a következő szempontok szerint vizsgáljuk:

(1.) az ionok felhalmozódása a határfelületen

(2.) a vízmolekulák egymás közötti kölcsönhatásának erősségét jellemző orientációs dinamika megváltozása

(3.) a fehérje és a hidratációs környezete közötti kölcsönhatási energia megváltozása

(4.) a kölcsönhatási energiaváltozás hatásának feltérképezése a fehérje-ion, fehérje-víz, illetve a fehérje első hidratációs burkában található víz-víz kölcsönhatásra fókuszálva

(5.) a fehérje térszerkezet szempontjából kiemelkedően fontos „felszínközeli” vízmolekulák kiszorulása ebből a régióból, illetve a fehérje és az ionok hidratációs burkainak átfedése

Ezen kérdések vizsgálathoz a szimulációk egy másik csoportját használtuk, nevezetesen olyan 100 ns hosszúságú, $300 \mathrm{~K}$-en végzett NPT dinamikákat értékeltünk ki, amelyekben a tc5b minifehérje kiindulási geometriáját harmonikus kényszerek segítségével fixen tartottuk. Referenciarendszerként továbbra is a tiszta vizes eset szolgál, a többi esetben pedig a vizsgált Hofmeister-aktív anionok nátrium sóit 1 mólos koncentrációban tartalmazta a modellrendszer. Az ioneloszlást és a vízmolekulák orientációs dinamikáját tekintve az összes vizsgált anionhoz tartozó eredményt áttekintjük. A kölcsönhatási energiát és a hidratációs burkok átfedését érintő kérdésekben pedig a tiszta vizes, valamint a $\mathrm{ClO}_{4}{ }^{-}$és $\mathrm{F}^{-}$ionokat (melyek a ,határesetek” a $\mathrm{HE}$ szempontjából) tartalmazó rendszerekkel foglalkozunk a jobb átláthatóság érdekében.

\subsubsection{Határfelületi ioneloszlás $[P 1]$}

A határfelületi ioneloszlás vizsgálatát RDF-ek segítségével végeztük el, melyeket az 16 . ábra mutat. Összességében megállapítható, hogy a kaotróp $\mathrm{ClO}_{4}{ }^{-}$és $\mathrm{NO}_{3}{ }^{-}$ionok felhalmozódnak a fehérje-víz határfelületen, ezzel ellentétben a kozmotróp $\mathrm{F}^{-}$és a Hofmesiter-semleges $\mathrm{Cl}^{-}$ionok kiszorulnak onnan.

A 16. ábrán látható, hogy a kaotróp ionok lokális koncentrációja jóval magasabb, mint a kozmotróp ionoké, már a legközelebbi határfelületi régióban $(0,3-0,5 \mathrm{~nm})$ is. Az egyes ionok határfelületi felhalmozódásának vizsgálatára az RDF-eken kívül az átlagos ionszámot is meghatároztuk. Az 1. táblázat tartalmazza azoknak az ionoknak és vízmolekuláknak az átlagos számát, amelyeknek legalább egy atomjuk legfeljebb $0,35 \mathrm{~nm}$ távolságra található a tc5b minifehérje tetszőleges atomjától. 

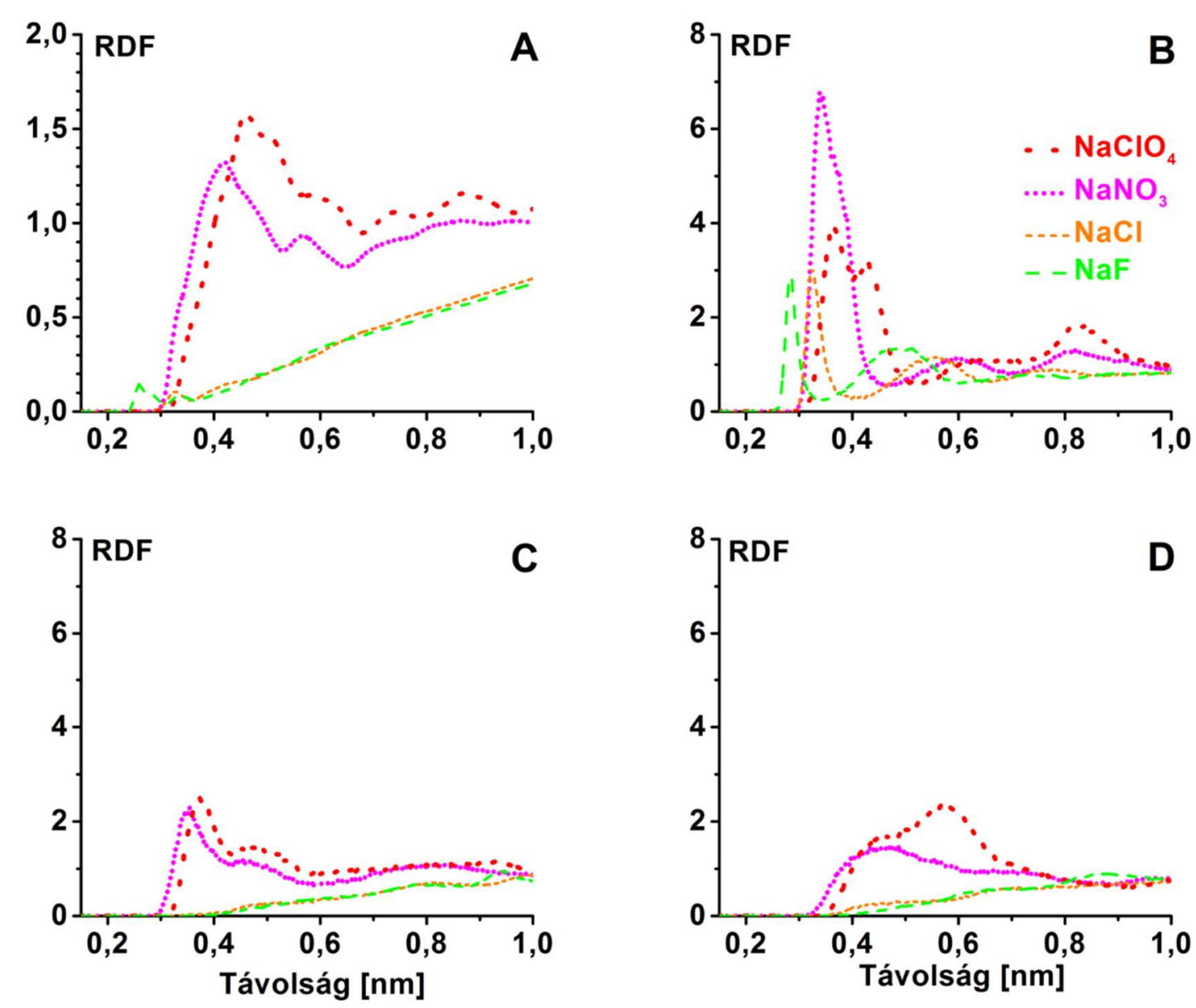

16. ábra Az oldott anionok központi atomjaink radiális eloszlása: (A) a fehérje nehéz atomjai körül; (B) a Lys ${ }^{8}$ aminosav töltött $\mathrm{N}$ atomja körül; (C) a Gly ${ }^{15}$ aminosav H-kötés donor $\mathrm{N}$ atomja körül; (D) a Pro $^{12}$ aminosav apoláros gyürüjének egy $\mathrm{C}$ atomja körül.

Összhangban az előző (RDF) eredményekkel, a $\mathrm{ClO}_{4}^{-}$ionok halmozódnak fel a legnagyobb mértékben a fehérjefelszínen, melyeket a $\mathrm{NO}_{3}{ }^{-}$ion követ; átlagosan, rendre 8,0 és 6,4 ion tartózkodik ebben a régióban. $\mathrm{A} \mathrm{F}^{-}$és a $\mathrm{Cl}^{-}$ionokhoz tartozó értékek jelentősen kisebbek, megközelítőleg 1,3. A Na ${ }^{+}$ionok átlagos száma rendre 2,3 és 2,7 az $\mathrm{NaClO}_{4}$ és $\mathrm{NaNO}_{3}$ sók esetében, míg valamivel kisebb $(1,7$ és 1,8$)$ a $\mathrm{NaCl}$ és $\mathrm{NaF}$ sók esetében.

\begin{tabular}{cccccc} 
& Tiszta Víz & $\mathrm{NaClO}_{4}$ & $\mathrm{NaNO}_{3}$ & $\mathrm{NaCl}$ & $\mathrm{NaF}$ \\
\hline \hline $\mathrm{H}_{2} \mathrm{O}$ & 131,5 & 115,3 & 123,2 & 129,8 & 129,8 \\
$\mathrm{Na}^{+}$ & - & 2,3 & 2,7 & 1,7 & 1,8 \\
anionok & - & 8,0 & 6,4 & 1,3 & 1,3 \\
\hline \hline
\end{tabular}

1. táblázat $\mathrm{A}$ tc $5 \mathrm{~b}$ minifehérjétől mért $0,35 \mathrm{~nm}$ távolságon belül található ionok és vízmolekulák átlagos száma.

Az ionok felhalmozódását nemcsak a teljes fehérje felszínre tekintettel végeztük el, hanem különböző töltéssel rendelkező régiókban is kiszámítottuk az RDF-eket. A 16.B-D ábrán 
láthatóak az anion-eloszlások eltérő felszíni töltéssel rendelkező karakterisztikus régiók körül: (B) a Lys $^{8}$ aminosav töltött $\mathrm{N}$ atomja; (C) a Gly ${ }^{15}$ aminosav föláncán található NH csoport $\mathrm{N}$ atomja; (D) a Pro ${ }^{12}$ aminosav apoláros gyürüjének egy $\mathrm{C}$ atomja. $\mathrm{A} \mathrm{F}^{-}$és a $\mathrm{Cl}^{-}$ionok figyelemre méltó felhalmozódása csak a (B) esetben figyelhető meg, azaz a legnagyobb oldószernek kitett

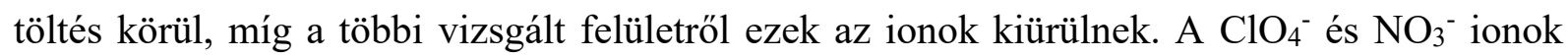
minden vizsgált régióban felhalmozódnak és a lokális ionkoncentráció tekintetében a felszíni töltés nagysága alapvető fontossággal bír a vizsgált atomcsoportok esetében. A leginkább kozmotróp és kaotróp hatású $\mathrm{F}^{-}$és $\mathrm{ClO}_{4}{ }^{-}$anionok térbeli eloszlását szemléleti a 17. ábra.

A kaotróp ionok fehérjefelszínen történő felhalmozódását kísérleti eszközökkel is kimutatták $[71,73]$, továbbá az - előző fejezet megállapításai szerint - jelenlétük csökkenti a fehérje-víz határfelületi feszültséget Dér és mtsi. [20] előrejelzéseinek megfelelően. Ahogy a 16. ábrán is látható, a kaotróp hatású ionok inkább felhalmazódnak a fehérjefelszínen és a felhalmozódást tekintve a felületi töltéssürüség fontos tényezőnek mutatkozik. Természetesen a felületi töltés mellett más faktorok is szerepet játszanak a lokális ionsürüség tekintetében, például a felszín geometriája, ahogy arra Gibb és mtsi. felhívták a figyelmet [68]. Nemrégiben több kísérleti és elméleti kutatás is kimutatta, hogy közvetlen kölcsönhatások lépnek fel a fehérje és a fehérjevíz határfelületen felgyülemlő kaotróp anionok között [71-74].

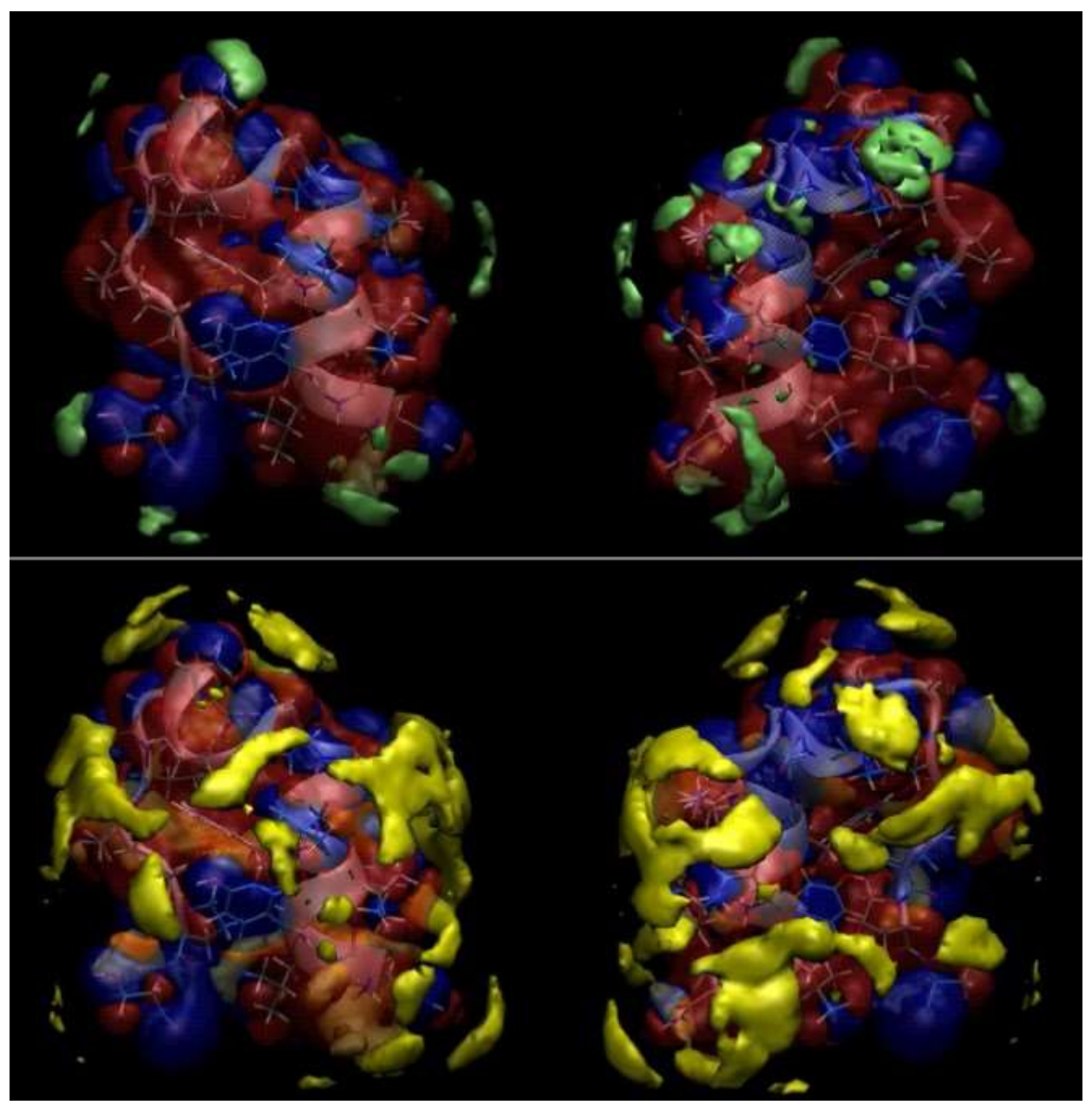

17.ábra $\mathrm{A} \mathrm{F}^{-}$(zöld) és $\mathrm{ClO}_{4}^{-}$(sárga) ionok eloszlása a minifehérje-víz határfelület közelében. 
Az RDF-ek ismeretében a felületi feszültség kiszámítása lehetséges más, nem SASA-alapú módszerek alkalmazásával is, melyek a Kirkwood-Buff elméletből eredeztethetőek. Ezek a felületi feszültség számolások az oldószer és az ionok fehérje körüli RDF-jeinek és az oldott ionok koncentrációinak segítségével történnek. Ebben az esetben azonban a konkrét SASAváltozásokat nem vesszük figyelembe, viszont a SASA-alapú megközelítéssel ellentétben fix fehérjefelszín mellett is elvégezhető a számolás. Horinek és mtsi. végeztek nem SASA-alapú felületi feszültség számolásokat [59]. Követve ezeket a módszereket kiszámoltuk a felületi feszültség változásokat [P1], melyek alacsony hőmérsékleten jó közelítéssel visszaadják a (21) összefüggés szerint kapott eredményeket. Ezt a nem SASA-alapú módszert alkalmazva az egyetlen kivétel a $\mathrm{NaCl}$ sót tartalmazó rendszer, mely esetben pozitív $\Delta \gamma$ értékeket kapunk a tiszta vizes esethez viszonyítva. Mindemellett, a vizsgált 300-360 K intervallumban az értékek hőmérséklettől való függést gyakorlatilag nem mutatnak.

\subsubsection{Vízmolekulák orientációs autokorrelációs függvényei [P1]}

Ahogy az korábban is megemlítésre került, a tömbfázisú vízhez képest az oldott anionok és fehérjék első hidratációs burkában a vízmolekulák orientációs dinamikája általában lassul. Most a tc $5 b$ minifehérje első oldási burkában lévő vízmolekulák orientációs tulajdonságainak az oldott anionok által kiváltott megváltozását vizsgáljuk meg, különös tekintettel azokra a régiókra, ahol jelentős az anionok felhalmozódása.

Az első hidratációs burokra jellemző távolságot a minifehérje körüli víz oxigén atomok RDFje segítségével állapítottuk meg. Ahogy a 18. ábrán látható az RDF függvénynek két közeli maximuma van, az első $\sim 0,19 \mathrm{~nm}$ távolságban, a másik pedig $\sim 0,28 \mathrm{~nm}$ távolságban. Ez a két régió együttesen alkotja az első hidratációs burkot, és az első maximumhoz tartozó vízmolekulák az $O-H$ kötésüket elfordítják a fehérje felszínétöl, így akceptor szerepet játszanak, míg a második csoport molekulái donorként viselkednek, a $\mathrm{H}$ atomot a felszín felé fordítva. Az első halmaz vízmolekulái (melyeknek oxigén atomjuk 0,23 nm-nél közelebb van a tc5b-hez) valószínűleg a pozitívan töltött felszínek környezetében találhatóak, a második halmaz vízmolekuláinak (melyeknek oxigénatomjuk 0,23-0,31 nm távol van a tc5b-től) pedig az összes többi régióban jellemző a jelenléte. Ezek a pozitívan töltött felszínek a kaotróp ionok kitüntetett felhalmozódási / kölcsönhatási helyei, ahogy azt a korábban bemutatott RDF-ek szolgáltatta eredményekből láthattuk (16. Ábra). 


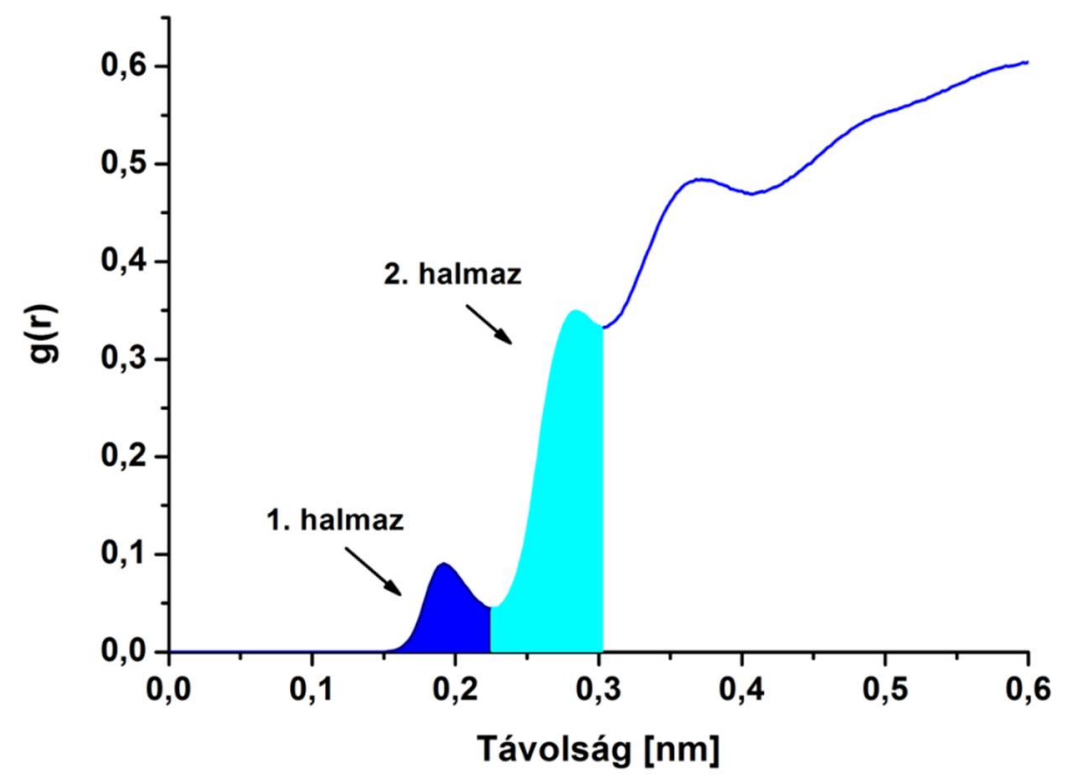

1. halmaz: $0 \mathrm{~nm}<\mathrm{d}<0,23 \mathrm{~nm}$

2. halmaz: $0,23 \mathrm{~nm}<\mathrm{d}<0,31 \mathrm{~nm}$


18. ábra Víz-oxigén atomok RDF-je a tc5b minifehérje körül (felül). A két kitüntetett csoport: 1 . akceptor vízmolekulák, 2. donor vízmolekulák szemléltetése (alul).

Viszonyítási alapként meghatároztuk a minifehérjétől $0,7 \mathrm{~nm}$ távolságban lévő $0,05 \mathrm{~nm}$ vastagságú tartományban található vízmolekulák átlagos orientációs autokorrelációs függvényeit mind a vizsgált ionok jelenlétében és azok hiányában (19. ábra), a tiszta vizes esetet tömbfázisnak tekintjük. A tiszta víz esetében a leggyorsabb az autokorrelációs függvények lecsengése, továbbá ezek a függvények az anionokat tekintve HS-nak megfelelő rendezettséget mutatnak: a leggyorsabb vízmolekula-reorientációt a perklorát jelenlétében láthatunk, míg a fluorid ionok lassítják a leginkább ezt a folyamatot.

Az orientációs autokorrelációs függvényéket a minifehérje első hidratációs burkában található vízmolekulák mindkét halmazára származtattuk (20. ábra). Összehasonlítva a 19. ábrán látható eredményekkel megállapítható, hogy a görbék lecsengése jelentősen lassabb a vízmolekulák mindkét halmazára, mint a tömbfázis esetében. Az 1-es halmaz vízmolekulái lassabban randomizálják a kezdeti orientációjukat, mint a 2-es halmazba tartozók mind az ionok jelenlétében, mind azok hiányában. 


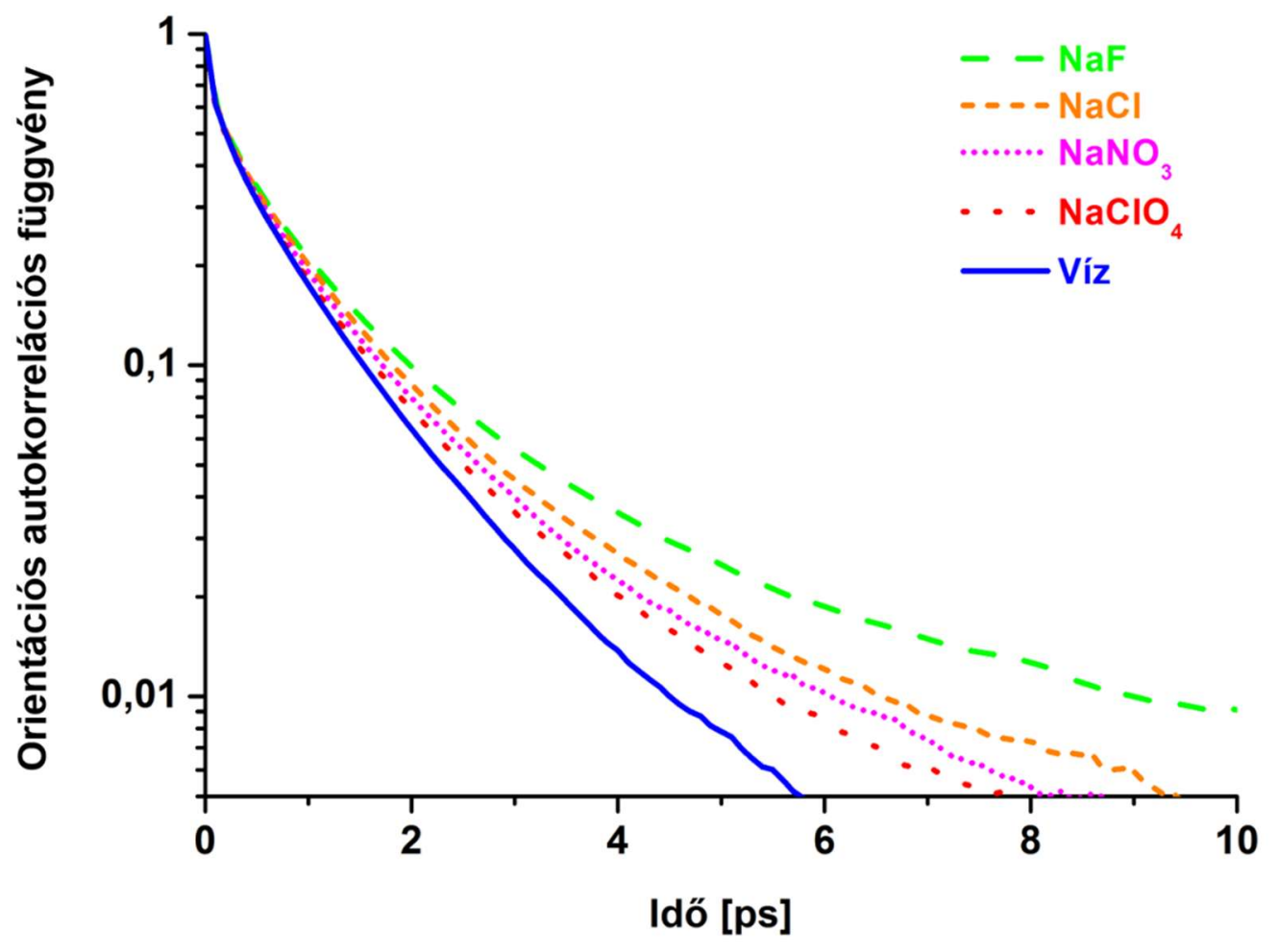

19. ábra Orientációs autokorrelációs függvény egy $0,05 \mathrm{~nm}$ vastagságú burokban a tc $5 \mathrm{~b}$ minifehérjétól mért $0,7 \mathrm{~nm}$ távolságban a vizsgált sók jelenlétében és azok hiányában.

A másik fontos megfigyelés, hogy az első hidratációs burokban található vízmolekulák két halmazának orientációs autokorrelációs függvényét eltérő módon befolyásolják az oldott anionok. A kaotróp anionok $\left(\mathrm{ClO}_{4}^{-}\right.$és $\left.\mathrm{NO}_{3}{ }^{-}\right)$gyorsítják, míg a $\mathrm{Cl}^{-}$és $\mathrm{F}^{-}$ionok lassítják a reorientációt a tiszta vizes esethez képest az 1-es halmaz esetében. Ugyanakkor a 2-es halmazt tekintve az összes anion lassítja ezt a folyamatot a tiszta vizes esettel összevetve és az egyes ionok hatása is hasonló mértékü. A határfelületen jelenlévő ionok mellett a minifehérje első hidratációs burkában található vízmolekulák tulajdonságai, különösen a határfelületi vízszerkezet stabilitása szintén meghatározó fontosságú tényezők. A HE mikroszkopikus szintü értelmezése már egy régóta tartó vita. A korábbi értelmezéseknek az volt az alapötlete, hogy a struktúra-építő, kozmotróp ionok erősítik, míg a struktúra-romboló, kaotróp ionok gyengítik a vízmolekulák közötti H-híd kötések erősségét nagy távolságokban [138]. Nemrégiben azonban számos kísérleti eredmény úgy tünik, ellentmond ennek az elképzelésnek. Omta és mtsi. spektroszkópiai módszerekkel vizsgálták a $\mathrm{Mg}\left(\mathrm{ClO}_{4}\right)_{2}, \mathrm{NaClO}_{4}$ és $\mathrm{Na}_{2} \mathrm{SO}_{4}$ sók oldatát [139], a vízmolekulák orientációs korrelációs idejét mérve. Munkájuk során megállapították, hogy az ionok csak az első hidratációs burkukban befolyásolják jelentősen a vízmolekulák tulajdonságait. Ugyanezt a hatást vizsgálták Stirnemann és mtsi. polarizációs erőteret és MD szimulációs eszközöket használva [140]. Magyarázatott adtak arra, hogy miért lassítja a vízmolekulák reorientációját minden magas koncentrációjú (megközelítőleg 1 mól feletti) sóoldat. A 18. ábrán látható, tömbfázisra vonatkozó eredményeink összhangban vannak ezekkel a megállapításokkal, megfelelnek az általuk kimutatott tendenciáknak. 

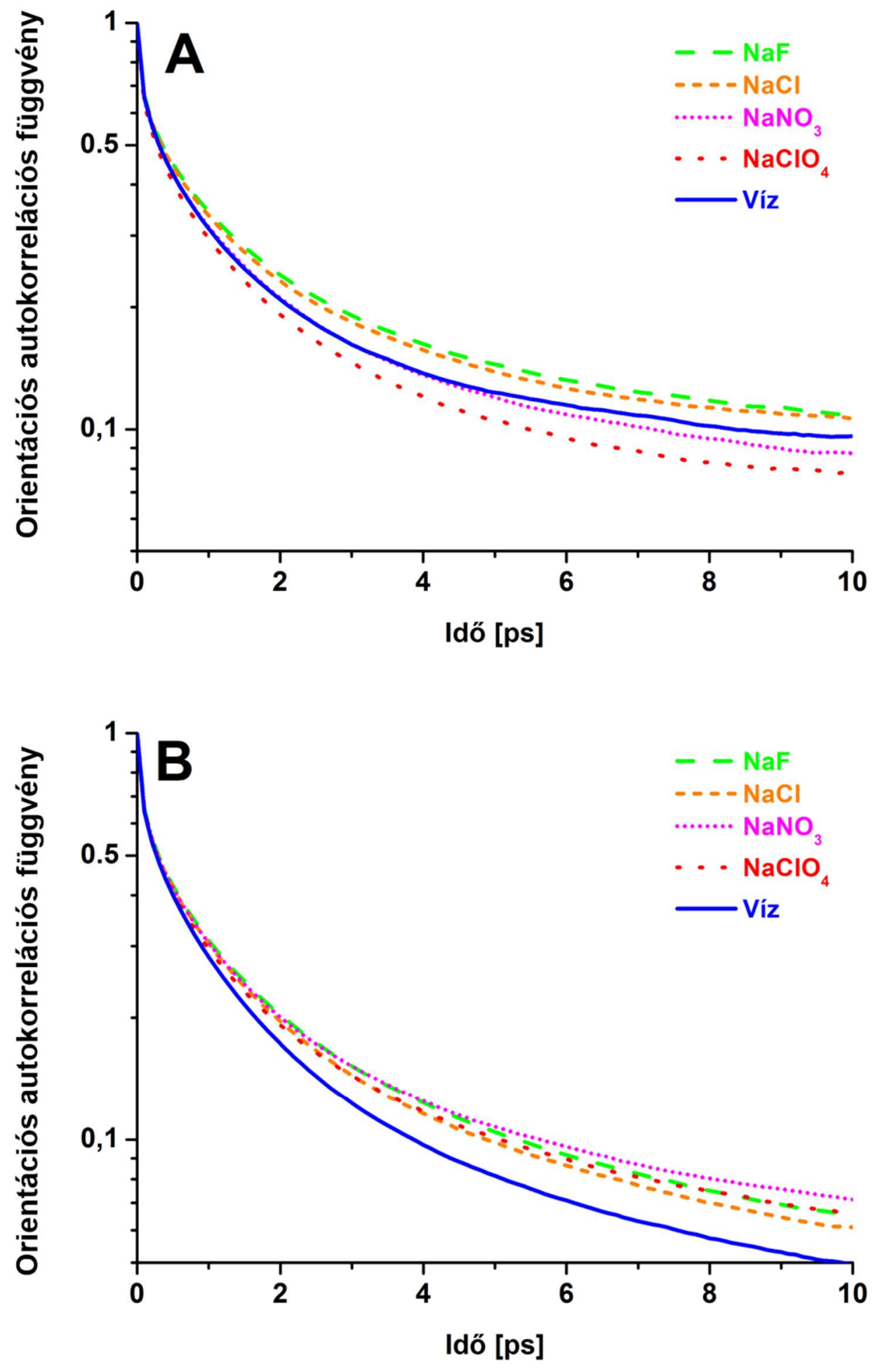

20. ábra Orientációs autokorrelációs függvények a vízmolekulák két halmazára: (A) oxigén atomjuk 0,23 nm-nél közelebb van a tc5b-hez és (B) oxigén atomjuk 0,23-0,31 nm távol van a tc5b-től; mind a vizsgált ionok jelenlétében, mind azok hiányában. 
A határfelületi víz orientációs dinamikájának lassulását spektroszkópiai módszerek segítségével kimutatták Aoki és mtsi., lizoszómák vizes oldatát használva teszt rendszernek [141], ugyanerre a következtetésre jutottak Perticaroli és mtsi. [142]. Emellett MD módszerek segítségével ugyanerre a rendszerre mutattak ki jelentős lassulást Sterpone és mtsi. [143].

Emellett, a vízmolekulák 1-es halmaza (a lehetséges akceptorok) esetében, melyek a pozitívan töltött határfelületi elemek körül találhatóak, az orientációs autokorrelációs függvények a HSnak megfelelö rendezettséget mutatnak (20. ábra). Ennek következtében feltételezhető, figyelembe véve a pozitív felszín feletti anion eloszlást (16. ábra) - hogy az első oldódás burokban tapasztalható reorientációs dinamika megváltozása a vízmolekulák közötti H-híd kötés rendszer megváltozását is jelzi, ahogyan azt kísérletileg is megfigyelték Hofmeister sók esetében [50, 51]. Valószínűleg az autokorrelációs függvények módosulása kapcsolatban áll a fehérje felszín közeli vízsűrüség fluktuációkkal is, ahogy azt Garde és mtsi. javasolták [144, 145], amely entrópikus jellegü járulékot adhat a felületi feszültséghez, azonban ez még igazolandó. Hasonlóan a határfelületi effektusok finom részleteihez, mint például a polarizáció szerepe a HE tekintetében [73, 146], ezek a kérdések későbbi vizsgálatok tárgyai lehetnek.

\subsubsection{A fehérje és hidratációs környezete közötti kölcsönhatási energia eloszlása [P3]}

A kaotróp és kozmotróp ionok rendre felhalmozódnak a fehérje-víz határfelület közelében, vagy kiszorulnak ebből a régióból (16. ábra, 1. táblázat). Mindkét esetben megváltozik a fehérje és a hidratációs környezete közötti kölcsönhatás. Annak érdekében, hogy nyomon követhessük ezeket a változásokat, kiszámoltuk a Coulomb és van der Waals kölcsönhatási energiák összegének az eloszlását. A számolásokat elvégeztük a fehérje és a teljes oldási környezete közötti kölcsönhatás vizsgálatára, illetve csak az ionokra és csak a vízmolekulákra tekintettel is. A 21.A ábrán látható a fehérje és a teljes hidratációs környezete közötti kölcsönhatási energia eloszlása. Megállapítható, hogy a $\mathrm{NaClO}_{4}$ só hozzáadására a görbe a negatívabb értékek irányába tolódik el, míg a NaF só ezzel ellentétes hatást vált ki a tiszta vizes esethez viszonyítva. Ennek a változásnak az eredete feltérképezhető az 21.B-C ábrák segítségével, melyek az ionok és a vízmolekulák kölcsönhatási energia hozzájárulásának eloszlását mutatják. A fehérje-víz kölcsönhatás mindkét vizsgált só jelenlétében csökken a tiszta vizes esethez viszonyítva (21.B ábra). Ugyanakkor a csökkenés mértéke jelentősebb a $\mathrm{NaClO}_{4}$ esetében, mint a $\mathrm{NaF}$ hozzáadásakor. Az ionok hozzájárulása a kölcsönhatási energiához jóval nagyobb a $\mathrm{NaClO}_{4} \mathrm{Só}$ esetén a NaF jelenlétéhez viszonyítva (21.C ábra). 

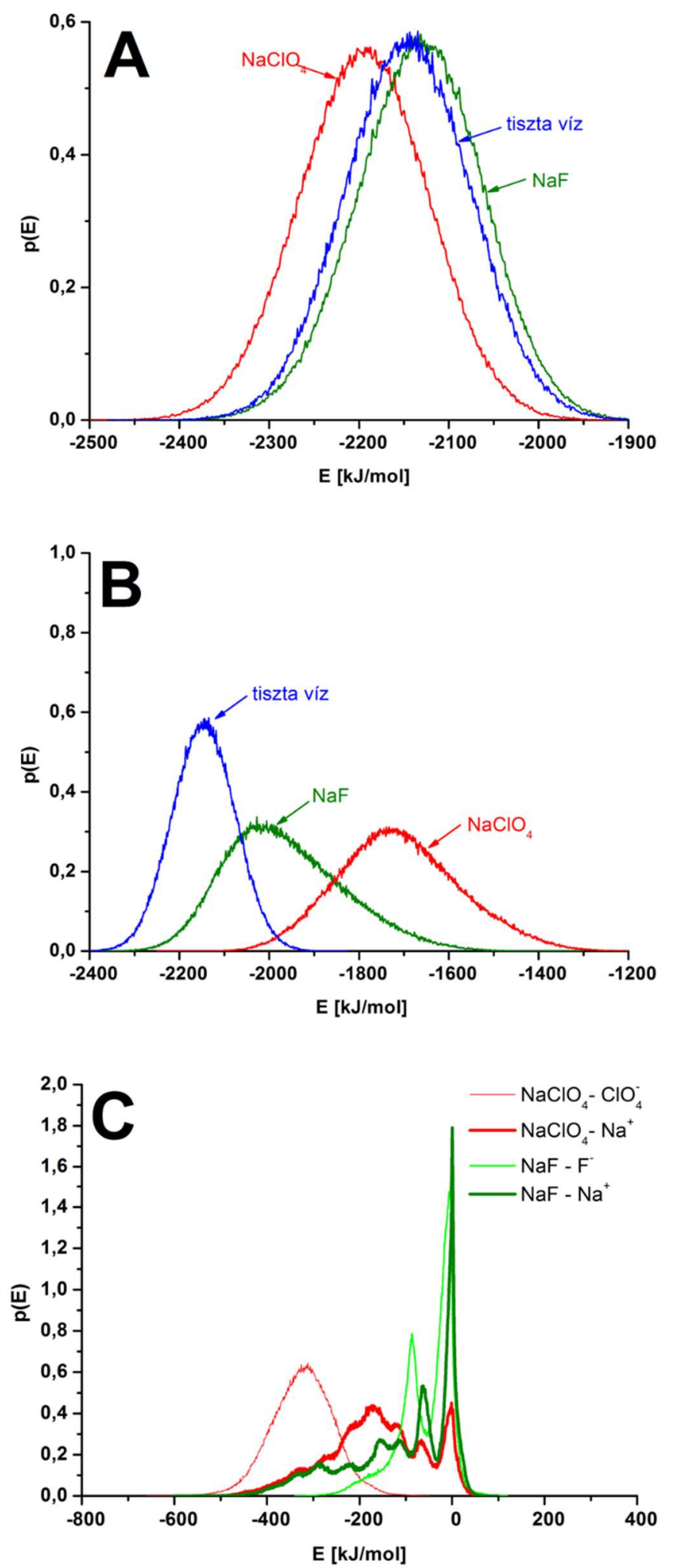

21. ábra Kölcsönhatási energia eloszlások (\%-ban) a $\mathrm{NaF}$ és a $\mathrm{NaClO}_{4}$ sók jelenlétében, illetve a tiszta vizes esetben, a tc5b minifehérjét és (A) teljes hidratációs környezetét-; (B) csak a vízmolekulákat- és (C) csak az ionokat figyelembe véve. 


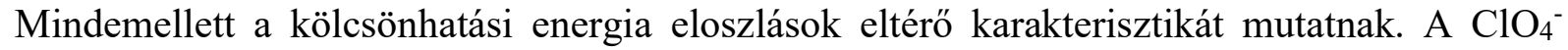
ionokhoz tartozó görbe simább és egy csúccsal rendelkezik, míg a $\mathrm{F}^{-}$ion esetében több csúcs is megfigyelhetö. A nátrium ionokhoz tartozó görbe hasonló a két vizsgált rendszerben, a kisebb eltérések valószínüleg az anionok határfelületi felhalmozódási sajátságai miatt jelentkeznek.

Habár a fehérje-víz kölcsönhatás nagyobb mértékben csökken a $\mathrm{NaClO}_{4}$ hozzáadásakor, mint a NaF esetében, összegezve az ionok hozzájárulásával a teljes kölcsönhatási energia nagyobb lesz, mint a tiszta vizes esetben. Ellenben a $\mathrm{NaF}$ só esetében az ionok hozzájárulása mérsékeltebb, így ez a kölcsönhatási energia járulék nem tudja pótolni a fehérje-víz kölcsönhatás tekintetében fellépő csökkenést, így a teljes kölcsönhatási energia kisebb lesz, mint a tiszta vizes esetben.

$\mathrm{A} \mathrm{NaClO}_{4}$ só hozzáadása a rendszerhez negatív irányba tolja el az eloszlást, míg a $\mathrm{NaF}$ só hatása ellentétes, ami rendre növekvő és csökkenő kölcsönhatást jelent (21.A ábra). Zhao és mtsi. kimutatták (explicit vizes MD szimulációk segítségével), hogy negatív korreláció áll fenn a hidratációs környezethez történő csatolás és a szerkezeti stabilitás között [147]. Alkalmazva ezeket az eredményeket a tc5b-s eredményekre a perklorát ion jelenléte destabilizálódást vált ki, míg a fluorid ion jelenléte stabilitásnövekedést jelez. Ezek a megfigyelések összhangban vannak kísérleti eredményekkel, valamint a kényszer eltávolítása mellett számolt REMD-ből származó adatokkal is (11. ábra). A tc5b minifehérje és a hidratációs környezete között számolt kölcsönhatási energia eloszlás (21.A ábra) egy entalpikus jellegü járulék a fehérje-víz határfelület szabadenergiájához. A határfelületi feszültség koncepció szerint ennek a felületnek az oldott ionok hatására bekövetkező szabadenergia-változásai „vezetik” a HE-t. Tulajdonképpen az előjele és az aránya a kölcsönhatási energia görbék eltolódásának megegyeznek az ionok által kiváltott felületi feszültség változásokkal (12. ábra), melyeket a SASA értékekből, illetve azok fluktuációiból származtattunk (1:5,5 arány, 300K hőmérsékleten). Ugyanakkor entalpikus tényezők mellett entrópikus járulékok is nyilvánvalóan fellépnek, mint például a fehérje-víz határfelülethez közeli vízmolekulák reorientációs dinamikájának a megváltozása (20. ábra), és azoknak is jelentős szerepük van a sók által kiváltott szabadenergia-változásokban.

\subsubsection{Fehérje-ion kölcsönhatás [P3]}

A kozmotróp és kaotróp ion eltérő kölcsönhatási energiaeloszlás görbéje (21.C ábra) arra enged következtetni, hogy a fehérje-ion kölcsönhatás különböző módokon történik a két anion esetében. A kölcsönhatási típusok azonosítása a DDCI görbék segítségével lehetséges. A DDCI számolásokat elvégeztük a teljes fehérjefelszín esetében, illetve a tc5b több kiválasztott kölcsönhatási helyére is. Ez utóbbiak töltött $\mathrm{N}$ atomok voltak a $\mathrm{Lys}^{8}, \mathrm{Arg}^{16}$ aminosavak lizil és guanidinium oldalláncain és az N-terminálison, melyeket a 22. ábra szemléltet. Ahogyan azt a 16. és 17. ábra is mutatja, a felületi töltésnek fontos szerepe van az ionok határfelületi felhalmozódásában. Ugyanakkor a fehérje-ion kölcsönhatás tekintetében a felületi töltésen kívül más jellemzők is szerepet játszhatnak abban az értelemben, hogy milyen típusú kölcsönhatás alakul ki az adott Hofmeister-aktív ion és a fehérje egy kitüntetett kölcsönhatási helye között. Az RDF eredmények (16. ábra) azt mutatták, hogy minél inkább kaotróp egy 
anion annál inkább felgyülemlik a fehérje-víz határfelületen, a perklorát esetében ez szinte minden nem negatív töltéssel rendelkező helyen megtörténik, ellenben a $\mathrm{F}^{-}$ionok csak a Lys ${ }^{8}$ $\mathrm{N}$ atomja körül halmozódnak fel. Azonban az RDF görbék maximumait tekintve nem határozható meg, hogy az anionok milyen hajlandósággal kapcsolódnak közvetlenül a tc5b-hez, illetve az esetek milyen hányadában történik vízmolekulák közvetítésével, azaz hidratációs burkok átfedésével, vagy összeérésével a kölcsönhatás. Ezek a tulajdonságok alapvetöen fontosak a 21.C ábra értelmezéséhez.

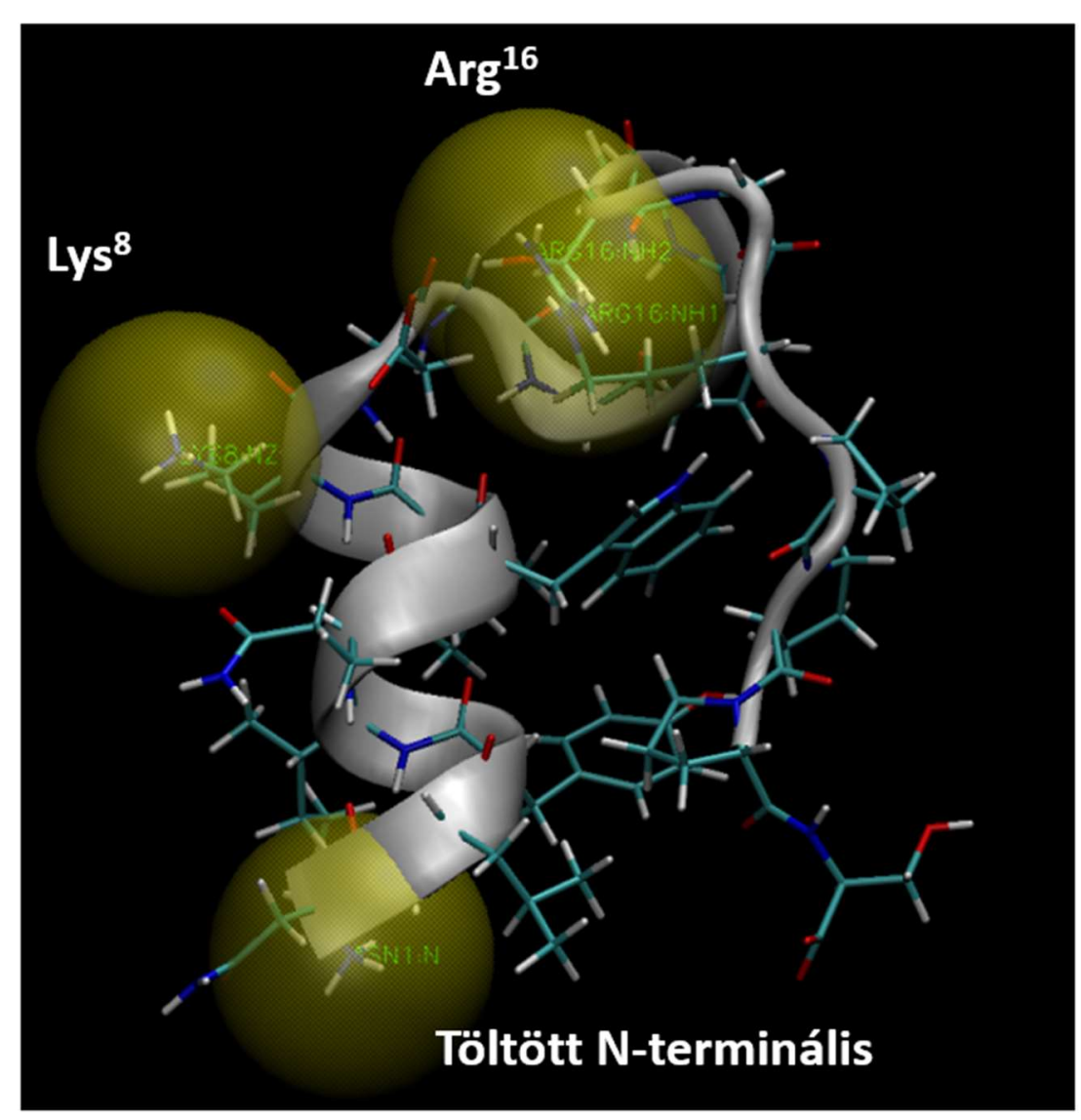

22. ábra A tc5b minifehérje vizsgált kölcsönhatási helyei a $\operatorname{Lys}^{8}, \operatorname{Arg}^{16}$ és $\mathrm{Asn}^{1}$ aminosavakon.

Az 23. ábrán látható a legközelebbi anionok tc5b minifehérjétől mért távolságának eloszlása, mely görbe eltérő karakterisztikával rendelkezik a leginkább kozmotróp és kaotróp ion esetében. $\mathrm{A} \mathrm{ClO}_{4}{ }^{-}$esetében ,egy csúcs” a jellemző, viszont a $\mathrm{F}^{-}$ion jelenlétében a DDCI görbe kettő, jól megkülönböztethető maximummal rendelkezik. Annak a valószínüsége, hogy egy perklorát ion megtalálható a minifehérjétől mért $0,25 \mathrm{~nm}$ távolságon belül 0,9997 . Következésképpen, szinte az egész szimuláció során legalább egy perklorát ion részt vesz egy $\mathrm{CP}$ típusú kölcsönhatásban a tc5b-vel. A kozmotróp $\mathrm{F}^{-}$ionok nem rendelkeznek ezzel a tulajdonsággal, a hozzájuk tartozó eloszlás egy mérsékeltebb csúccsal rendelkezik $0,17 \mathrm{~nm}$ távolságban, melyet egy minimum követ $0,25 \mathrm{~nm}$ távolságban, de 0,25 és $0,8 \mathrm{~nm}$ közötti távolságok is realizálódnak. Annak a valószínüsége, hogy a tc5b-től mért 0,25 nm-es távolságon belül találunk egy, $\mathrm{CP}$ típusú kölcsönhatásban résztvevő $\mathrm{F}^{-}$iont, mindössze 0,4233 . A második és kevésbé éles maximuma ennek a görbének $0,37 \mathrm{~nm}$ távolságban található, ami 0,2 nm-es eltolódás az elsőhöz képest. Ez az eltolódás hasonló nagyságrendü, mint a $\mathrm{F}^{-}$ionok első 
hidratációs burkának a vastagsága, mely a víz-oxigén atomokra való tekintettel 0,23-0,32 nm nagyságú (lásd Függelék $1 \mathrm{~F}$. ábra és $1 \mathrm{~F}$. táblázat). Ez a tulajdonság a $\mathrm{F}^{-}$ionok hidratációs burkának legalább részleges megőrzését, illetve SSP típusú kölcsönhatás létrejöttét jelzi.

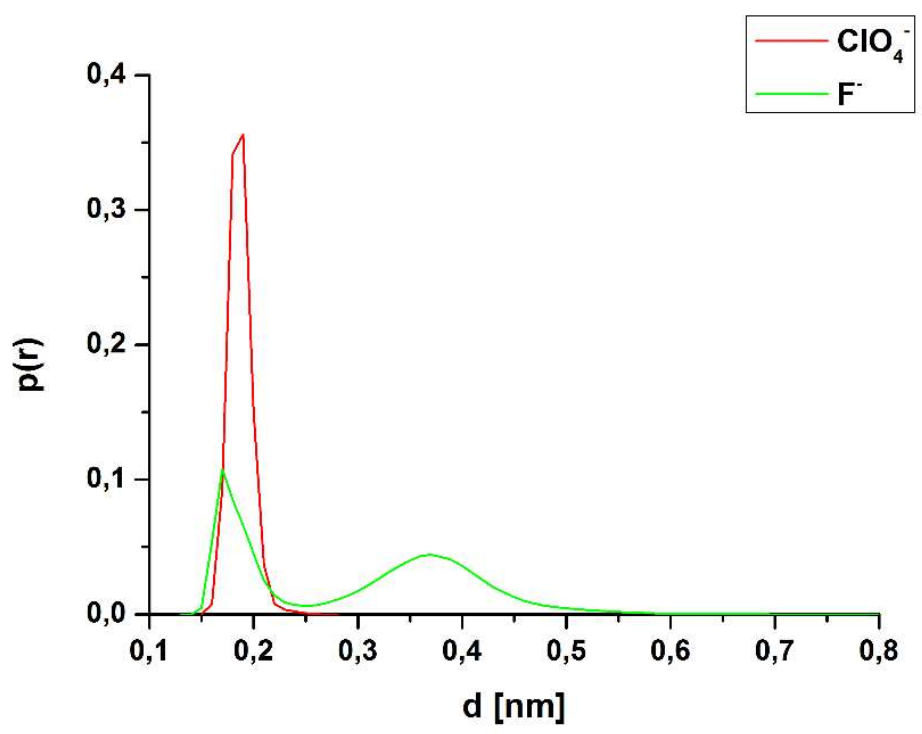

23. ábra $\mathrm{A} \mathrm{F}^{-}$és $\mathrm{ClO}_{4}^{-}$ionokhoz tartozó DDCI görbék a tc5b minfehérje esetén számolva.

Mindemellett a kölcsönhatási típusok jóval részletesebb feltérképezése is lehetséges a DDCI görbék segítségével. Megvizsgáltuk a $\mathrm{F}^{-}$és $\mathrm{ClO}_{4}^{-}$ionok párképzési alkalmasságát a tc5b minifehérje protonált csoportjai esetében. A DDCI görbék származtatást elvégeztük a Lys ${ }^{8}$ aminosav oldalláncának töltött $\mathrm{N}$ atomjára, $\mathrm{az} \operatorname{Arg}^{16}$ aminosav oldalláncának töltött $\mathrm{N}$ atomjaira, illetve az $\mathrm{N}$-terminálison található $\alpha$-amino csoport töltött $\mathrm{N}$ atomjára való tekintettel (24. ábra). Ezekben az esetekben a $\mathrm{F}^{-}$ion DDCI görbéi már három maximummal rendelkeznek, ellentétben a teljes tc5b-hez tartozó görbével. Ez a három régió a CP, SSP és 2SP típusú kölcsönhatásoknak feleltethetőek meg, melyek közvetlen-, illetve egy-, vagy több vízmolekula által közvetített kölcsönhatást jelez. Ezzel szemben a $\mathrm{ClO}_{4}^{-}$ionhoz tartozó görbék közül továbbra is egy maximummal rendelkezik az N-terminális $\mathrm{NH}_{3}{ }^{+}$csoportjának $\mathrm{N}$ atomjához tartozó, míg a másik két esetben egy második maximum is azonosítható. Következésképpen, ez utóbbi két esetben a kaotróp anion esetén is megjelennek az SSP és a 2SP típusú kölcsönhatások, míg az N-terminális közelében szinte csak a CP kölcsönhatás azonosítható. Az N-terminálishoz, a Lys ${ }^{8}$-hoz és az Arg $^{16}$-hoz tartozó DDCI görbéken található minimumok közel esnek egymáshoz. A F- ionokhoz tartozó görbéknél a minimumok helye 0,35 és $0,65 \mathrm{~nm}$, míg $\mathrm{ClO}_{4}^{-}$ion görbéjénél a minimum helye $0,38 \mathrm{~nm}$.

Az egyes kölcsönhatások kialakulását jellemző valószínűségeket az 2. táblázat tartalmazza. 

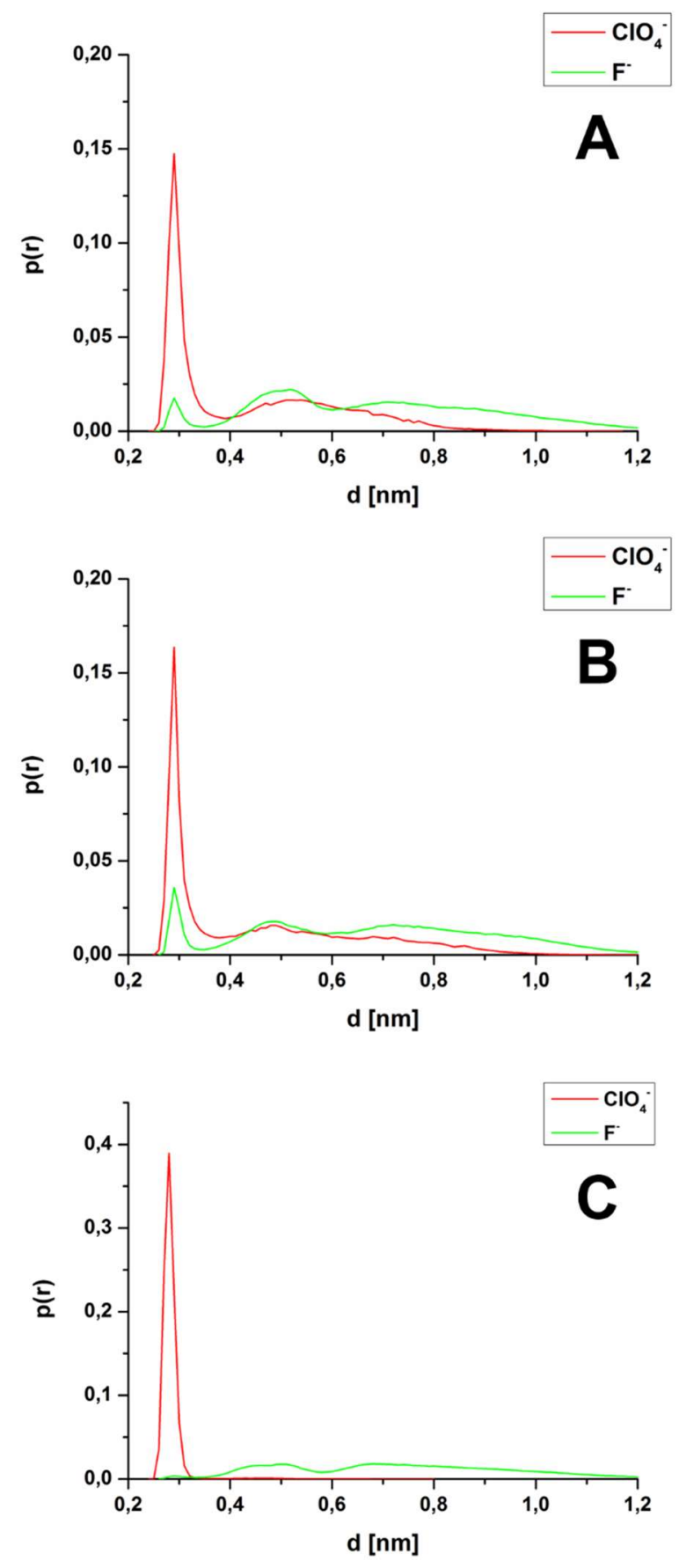

24. ábra A vizsgált anionok DDCI görbéi: (A) Lys ${ }^{8}-$; (B) $\operatorname{Arg}^{16}$ oldallánc töltött $\mathrm{N}$ atomjaira és (C) az $\mathrm{N}$-terminális $\mathrm{NH}_{3}{ }^{+}$csoportjának $\mathrm{N}$ atomjára vonatkoztatva.

Az egész tc5b-re vonatkozó DDCI görbénél megjelenő, egy maximummal rendelkező, a kaotróp $\mathrm{ClO}_{4}{ }^{-}$anionhoz tartozó karakterisztika valószínűleg az N-terminálisnál létrejövő $\mathrm{CP}$ típusú kölcsönhatás következménye. Másrészt az összes vizsgált atomcsoport esetében az oldószer által közvetített kölcsönhatások a meghatározóak a $\mathrm{F}^{-}$ionok számára, továbbá a 2SP típus preferáltabb az SSP-nél, mindez az N-terminálisnál jelenik meg a legjellemzőbben. 


\begin{tabular}{c|ccc}
\hline \hline & Lys8 & Arg16 & N-terminális $\mathrm{NH}_{3}^{+}$ \\
\hline \hline $\mathrm{ClO}_{4}^{-}$ & & & \\
$\mathrm{CP}$ & 0,5320 & 0,5083 & 0,9997 \\
$\mathrm{SSP}$ & 0,4414 & 0,4324 & 0,0003 \\
$2 \mathrm{SP}$ & 0,0266 & 0,0593 & 0,0000 \\
\hline \hline $\mathrm{F}^{-}$ & & & \\
$\mathrm{CP}$ & 0,0601 & 0,1043 & 0,0122 \\
$\mathrm{SSP}$ & 0,3652 & 0,3101 & 0,2810 \\
$\mathrm{SP}$ & 0,5747 & 0,5856 & 0,7068 \\
\hline \hline
\end{tabular}

2. táblázat $\mathrm{A} C P, \mathrm{SSP}$ és $2 \mathrm{SP}$ típusú kölcsönhatások megvalósulási valószínűségei a három vizsgált töltött atomcsoportra ( $\mathrm{Lys}^{8}-; \mathrm{Arg}^{16}$ oldallánc töltött $\mathrm{N}$ atomjaira és az $\mathrm{N}$-terminális $\mathrm{NH}_{3}{ }^{+}$csoportjának $\mathrm{N}$ atomjára) vonatkozóan.

Az eddig vizsgált kölcsönhatási helyek mind jelentős pozitív töltéssel rendelkeztek, azonban felmerül a kérdés, hogy például a fölánc NH csoportjai mennyire preferált kölcsönhatási helyek. A $\mathrm{F}^{-}$ionok esetében már az RDF eredmények (16. ábra) után kizárható a $\mathrm{CP}$ típusú kölcsönhatás, hiszen a Lys $^{8}$ aminosav $\mathrm{N}$ atomján kívül más jelentős felhalmozódás sehol sem volt tapasztalható, amit a DDCI görbék (24. ábra) is megerősítettek.

A perklorát ion esetében ennek a kérdésnek a vizsgálatára kiválasztottunk a $\operatorname{Ser}^{14}$, $\mathrm{Gly}^{15}$ és $\operatorname{Arg}^{16}$ aminosavak fölánc NH csoportjait és elvégeztük a DDCI számolást (az N atomoktól mérve a távolságot), amit a 25. ábra mutat.

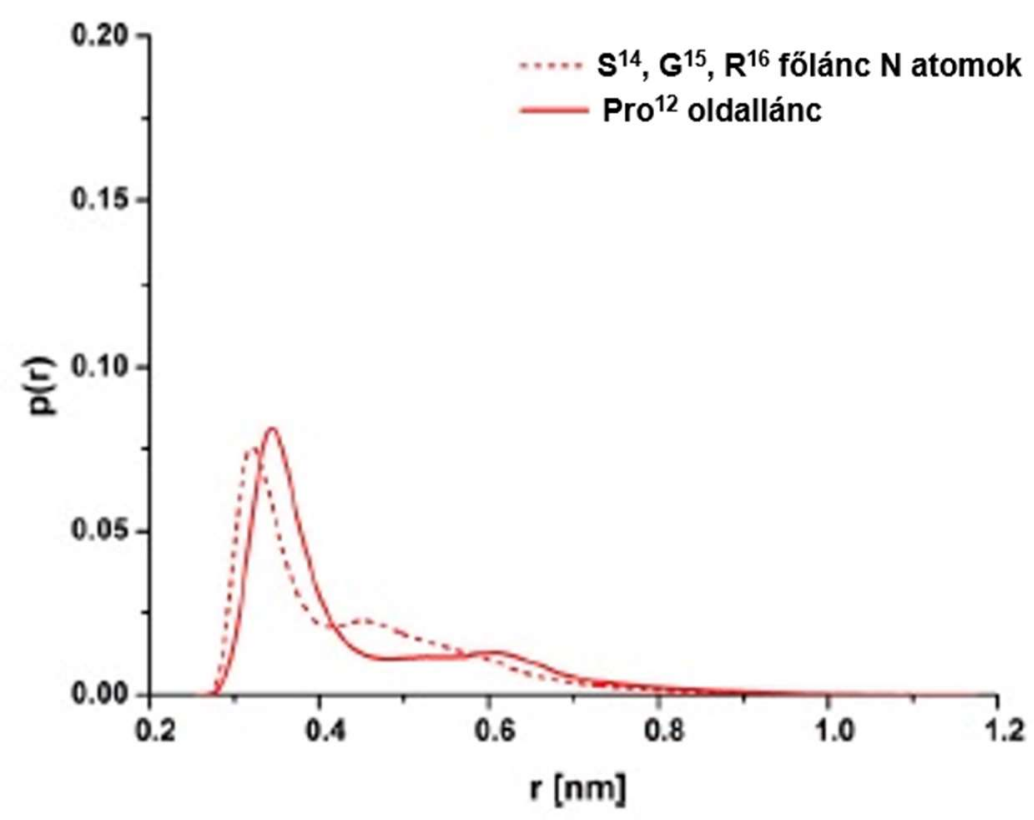

25. ábra DDCI görbék a perklorát ionok és a tc5b (i) $\operatorname{Pro}^{12}$ oldallánc nehézatomjai; és (ii) a $\mathrm{Ser}^{14}$, Gly $^{15}$ és $\operatorname{Arg}^{16}$ aminosavak fölánc $\mathrm{N}$ atomjai között számolva.

Ezek az atomok jóval kisebb parciális töltéssel rendelkeznek, mint a protonált csoportoknál vizsgáltak, de a fehérjefelszín egy konkáv régiójában helyezkednek el. A DDCI görbe első 
csúcsa (ami a CP kölcsönhatáshoz tartozik) szélesebb, mint a töltött csoportok esetében és a kumulatív valószínüsége a közvetlen kölcsönhatásnak 0,5564. Ez az érték magasabb a Lys ${ }^{8}$ és az $\operatorname{Arg}^{16}$ aminosavaknál látottaknál (2. táblázat). A Pro ${ }^{12}$ aminosav (ami egy a térszerkezeti stabilitás szempontjából fontos hosszútávú hidrofób kölcsönhatásban vesz részt a $\operatorname{Trp}^{6}$ aminosavval) oldalláncán található $\mathrm{H}$ atomok parciális töltése még a fölánc $\mathrm{NH}$ csoportokéinál is kisebb. Ennek ellenére a DDCI görbe hasonló karakterisztikájú, mint az előző esetben (25. ábra) és ezen atomok és a $\mathrm{ClO}_{4}^{-}$ionok közötti CP-típusú kölcsönhatás kialakulásának valószínüsége 0,5403. Ebben az esetben a perklorát ionok szintén egy sekély mélyedésben helyezkednek el a Pro ${ }^{12}$ aminosav közvetlen szomszédságában.

A 23-25. ábrákon bemutatott párképződési tulajdonságok összhangban vannak a Collinsszabállyal. Ennek az empirikus törvénynek az az alapvető állítása, hogy egy anion és egy kation akkor preferálhatja a párformálódást, ha mindkettő vagy kaotróp, vagy kozmotróp. A vizsgált kaotróp tulajdonságú, pozitív töltésü kölcsönhatási helyek a szintén kaotróp $\mathrm{ClO}_{4}^{-}$ionnal közvetlen kölcsönhatásba lépnek, azonban a kozmotróp $\mathrm{F}^{-}$ionok esetén nem ez a meghatározó kölcsönhatási típus. Ahogy azt korábban kimutattuk (16. ábra), a felületi töltés az egyik fontos tényező, ami befolyásolja az ionfelhalmozódást a fehérje-víz határfelületen, és főként a kaotróp ionok halmozódnak fel pozitív felületi töltéssel rendelkező felületeken. Mindazonáltal, a közvetlen kölcsönhatás preferálása tekintetében nincs erős korreláció a felületi töltés nagysága és a CP-típusú kölcsönhatás kialakulási valószínűsége között. Ugyanis a protonált oldalláncok (2. táblázat) és a jóval kisebb parciális töltéssel rendelkező kötési helyek (25. ábra) megközelítőleg ugyanolyan mértékben kötik meg a perklorát ionokat. Cremer és mtsi. kimutatták korábban [73], hogy a fölánc amid csoportjaival létrejövő közvetlen kölcsönhatás a kaotróp ionok esetén preferált. Az alacsonyabb felületi töltéssel rendelkezö kölcsönhatási helyek esetén pedig egyáltalán nem azonosítható CP-típusú kölcsönhatás a $\mathrm{F}^{-}$ionok esetében. Azonban az $\mathrm{Asn}^{1}$ aminosavnál található $\mathrm{NH}_{3}{ }^{+}$csoport egy felületi mélyedésben található, és ezen a kölcsönhatási helyen szinte a teljes szimulációban található CP-típusú kölcsönhatásban résztvevő perklorát ion, ami vízmolekulák állandó kiszorítását is jelenti ebből a régióból. Tehát az a következtetés vonható le, hogy a perklorát ionok oldódása / felületi kötődése erősen függ a felületi töltés nagyságától és emellett még az adott kötési hely környezetének geometriájától is. Összességében megállapítható, hogy az ionok és vízmolekulák eloszlási tulajdonságai egy fehérje-elektrolit határon elektrosztatikus és térbeli kényszereknek vannak alávetve, ami entrópiacsökkenést eredményez, és ennek megfelelően módosítja a rendszer szabadenergiáját. A lokális hidratációs sajátosságok feltérképezése megvilágíthat fontos tulajdonságokat a fehérje, vízmolekulák és ionok alkotta komplex kölcsönhatási rendszert illetően.

Ezek a fehérje-ion kölcsönhatási különbségek ugyanakkor magyarázattal szolgálnak a 21.C ábrán bemutatott kölcsönhatási energia eloszlások eltérő karakterisztikájára. Mivel a $\mathrm{ClO}_{4}{ }^{-}$ ionok számára a CP-típusú kölcsönhatás a preferált, a protonált- és a kisebb parciális töltésü kölcsönhatási helyeken egyaránt, ezért a perklorát ionokhoz tartozó kölcsönhatási energia eloszlásban $-100 \mathrm{~kJ} / \mathrm{mol}$ és $-600 \mathrm{~kJ} / \mathrm{mol}$ közötti értékek is előfordulnak. Ezzel ellentétben a $\mathrm{F}^{-}$ ionok a vízmolekulák által közvetített kölcsönhatásokat (SSP, 2SP) preferálják, a CP-típusúval szemben, az összes vizsgált kölcsönhatási helyen. Ezen túl, ez a megállapítás a teljes fehérjefelszínre is igaz (23. ábra), mivel ebben az esetben is a CP-típusú kölcsönhatás 
valószínúsége jelentősen 0,5 alatt van, ugyanakkor az SSP típus a jellemző ebben az esetben, a 2SP-típus valószínűsége pedig elhanyagolható. Ez azt is jelenti, a szimulációs idő nagyobb hányadában van legalább egy olyan $\mathrm{F}^{-}$ion a határfelület közelében, mely osztozik a hidratációs burkán a minifehérjével, és túlnyomórészt a $\mathrm{F}^{-}$ionok inkább kiürülnek a fehérje-víz határfelület egészéről. Ez a tulajdonság megfelel a kapcsolódó kölcsönhatási energia eloszlás profiljának, ugyanis a nulla közeli értékek mutatkoznak dominánsnak.

\subsubsection{Határfelületi vízmolekulák kölcsönhatási energia szerinti felosztása és a kapcsolódó orientációs autokorrelációs függvények [P3]}

A tc5b minifehérje első hidratációs burkában található vízmolekulák orientációs tulajdonságait illetve az anionok indukálta hatásokat már áttekintettük (6.4.2 szakasz), méghozzá azon osztályozás mellett, hogy a vízmolekulák donor, vagy akceptor szerepet játszanak. Mindazonáltal a minifehérje és a vízmolekulák közötti kölcsönhatási energia szempontjából is osztályozhatjuk a tc5b első hidratációs burkában található vízmolekulákat. A vízmolekulák kölcsönhatási energia szerinti eloszlását a 26. ábra mutatja, amit az NPT szimuláció utolsó 50 ns-os részében egyenletesen elosztott 25.000 időpillanat adatait felhasználva számítottunk ki, a tiszta vizes esetben, továbbá a $\mathrm{ClO}_{4}{ }^{-}$és $\mathrm{F}^{-}$ionokat tartalmazó rendszerekre.

A 26.A ábrán látható energia eloszlás 3 intervallumra osztható: $-14 \mathrm{~kJ} / \mathrm{mol}$ értéknél nagyobbra $\left(E_{1}\right),-40$ és $-14 \mathrm{~kJ} / \mathrm{mol}$ közötti $\left(E_{2}\right)$ és $-40 \mathrm{~kJ} / \mathrm{mol}$ értéknél kisebbre $\left(E_{3}\right)$. Ahogy az várható is, a legerösebben kötött vízmolekulák a töltött csoportok környezetében találhatóak, a gyengén kötöttek pedig a hidrofób felületelemek közelében.

A 27. ábra a MD trajektória egy időpillanatában mutatja a fenti 3 energiacsoporthoz tartozó vízmolekulák oxigén atomjainak térbeli eloszlását. Az oldott ionok által kiváltott eloszlásbeli különbségek kihangsúlyozása érdekében a tiszta vizes esethez tartozó eloszlást levontuk a kozmotróp és kaotróp ionok esetén számolt eloszlásokból (26.B ábra). Megállapítható, hogy az eltérések sokkal jelentősebbek a $\mathrm{ClO}_{4}{ }^{-}$ionok jelenlétében, mint a $\mathrm{F}^{-}$ionok esetében. A NaF só hozzáadására az erősen kölcsönható vízmolekulák száma enyhén csökken a negatív kölcsönhatási energia régióban, ugyanakkor a pozitív kölcsönhatási energiával rendelkező vízmolekulák száma valamelyest megnövekszik. A kaotróp anion esetében pedig a közepesenés az erősen kötött vízmolekulák száma az $E_{2}$ és $E_{3}$ intervallumokban, valamivel jobban csökken, mint a kozmotróp ionok jelenlétében. A gyengébben kötött vizek esetében $\left(E_{1}\right.$ intervallum) a görbék jelentősen nagyobb különbséget mutatnak, a $\mathrm{NaClO}_{4}$ sót tartalmazó rendszerekben, ezeknek a vízmolekuláknak a száma sokkal kisebb negatív kölcsönhatási energia esetén, mint a pozitív kölcsönhatási energia tartományban. 


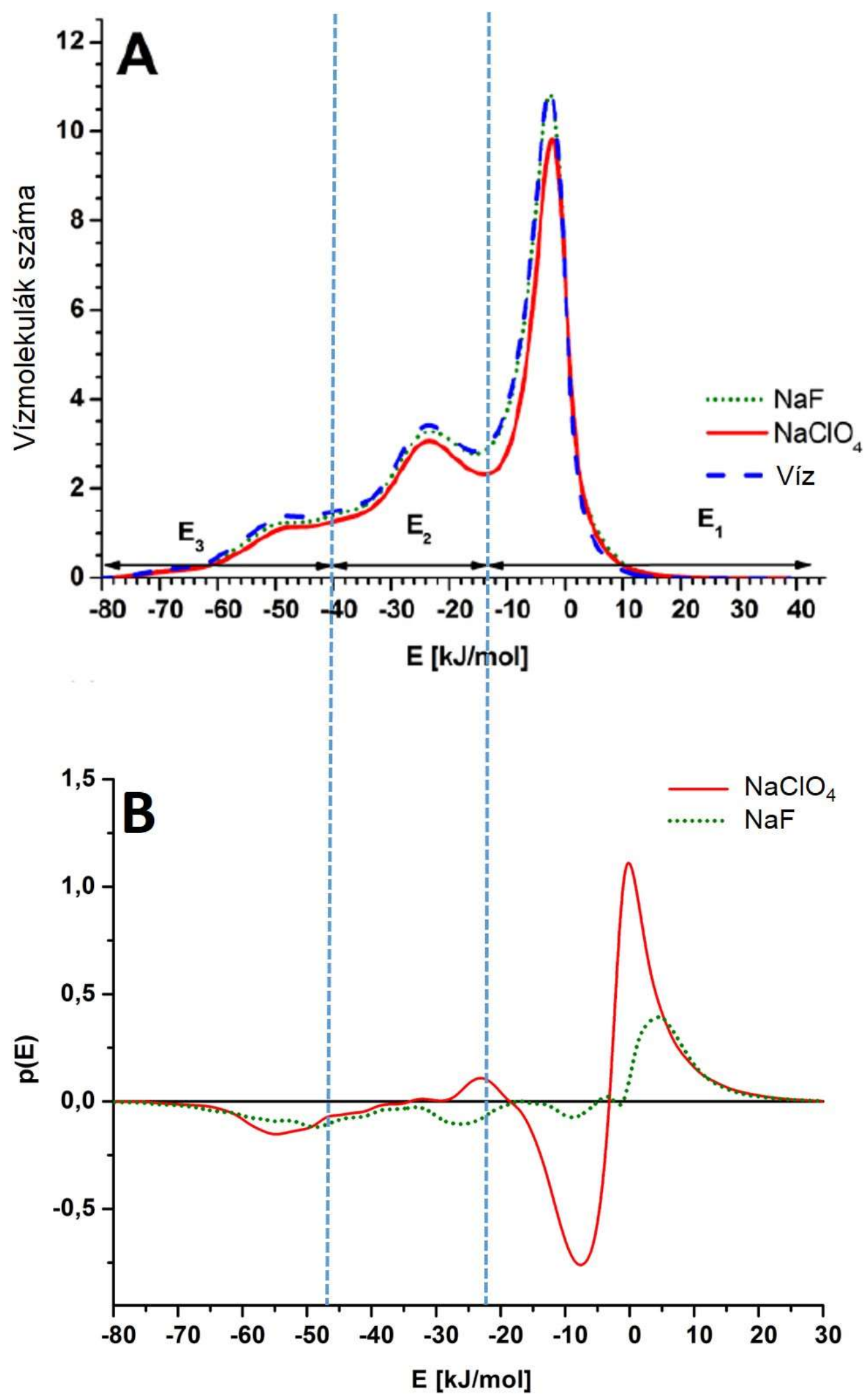

26. ábra (A) a tc5b minifehérje első hidratációs burkában található vízmolekulák kölcsönhatási energia eloszlása és (B) a minifehérje első hidratációs burkában számolt fenti eloszlások különbsége a $\mathrm{NaF}$ és a $\mathrm{NaClO}_{4}$ sókat tartalmazó rendszerekre a tiszta vizes értékektől. 


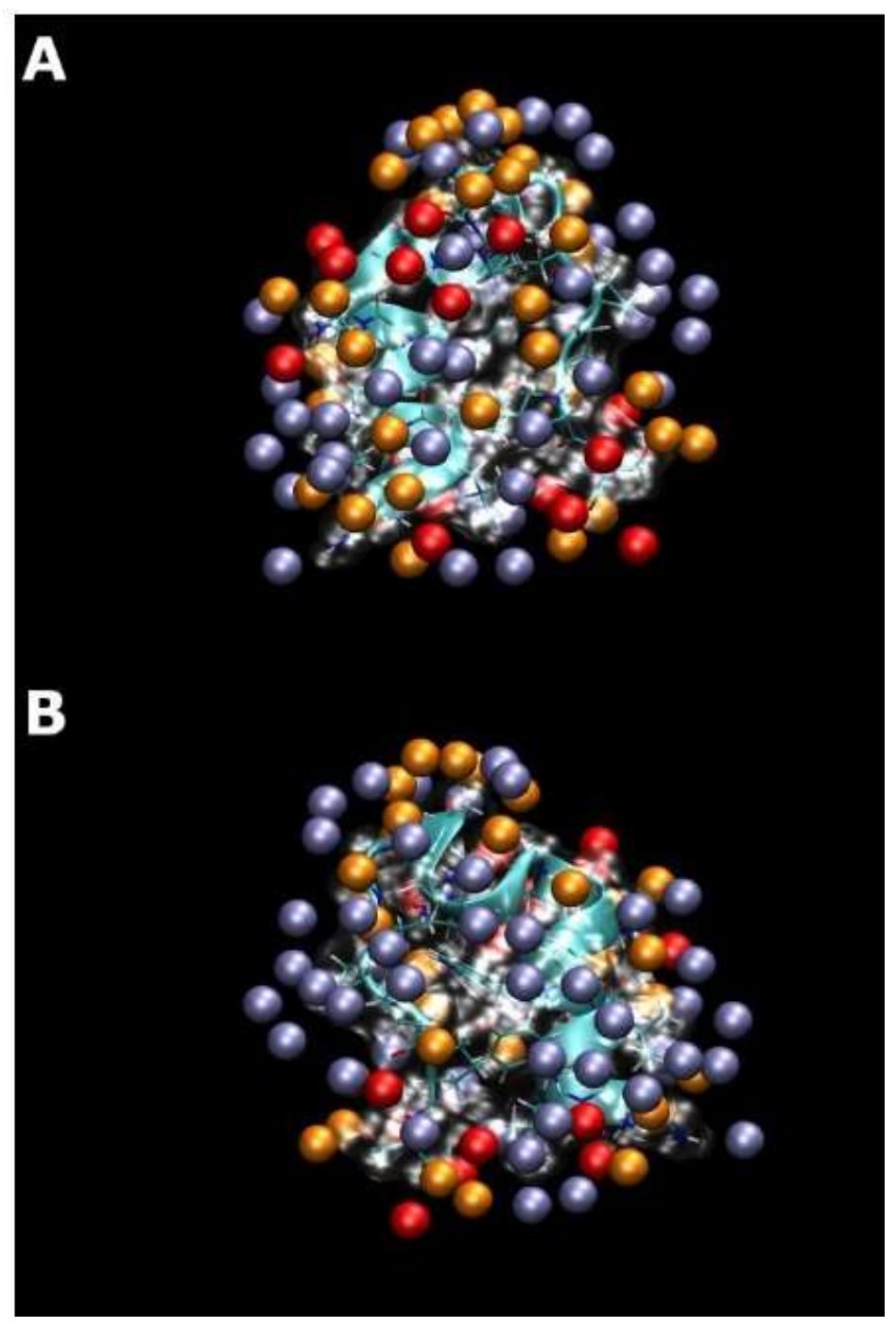

27. ábra $A$ minifehérje első hidratációs burkában található vízmolekulák $O$ atomjai a kölcsönhatási energiájuk szerint színezve: kék $\left(E_{1}\right)$, narancssárga $\left(E_{2}\right)$ és piros $\left(E_{3}\right)$. A sóhíd felöli oldalt az ábra (A), míg az ellentétest a $(B)$ része mutatja.

A 26.B ábra alatti integrál arányos az első hidratációs burok vízszám-változásával. A vízmolekulák kiszorulása ebből a régióból sokkal nagyobb a perklorát ionok esetén (átlagosan 12,8 vízmolekula), mint a fluorid ionok jelenlétében (átlagosan 1,3 vízmolekula). Megemlítendő még, hogy mindkét aniont tartalmazó rendszerben megnő a pozitív kölcsönhatási energiával rendelkező vízmolekulák száma. Ez azt jelenti, hogy mindkét esetben több az olyan vízmolekula, amely számára kedvezőtlen a tc5b-vel létrejövő kölcsönhatás.

Ahogy azt korábban láttuk, pozitívan töltött csoportok közelében a vízmolekulák reorientációja gyorsabb lesz a kaotróp ionok jelenlétében és lassabb a kozmotróp ionok jelenlétében, a tiszta vizes esethez viszonyítva. Ezt a vizsgálatot elvégezhetjük a minifehérje első hidratációs burkában a három fentebb definiált energia csoportba tartozó vízmolekulákra. 

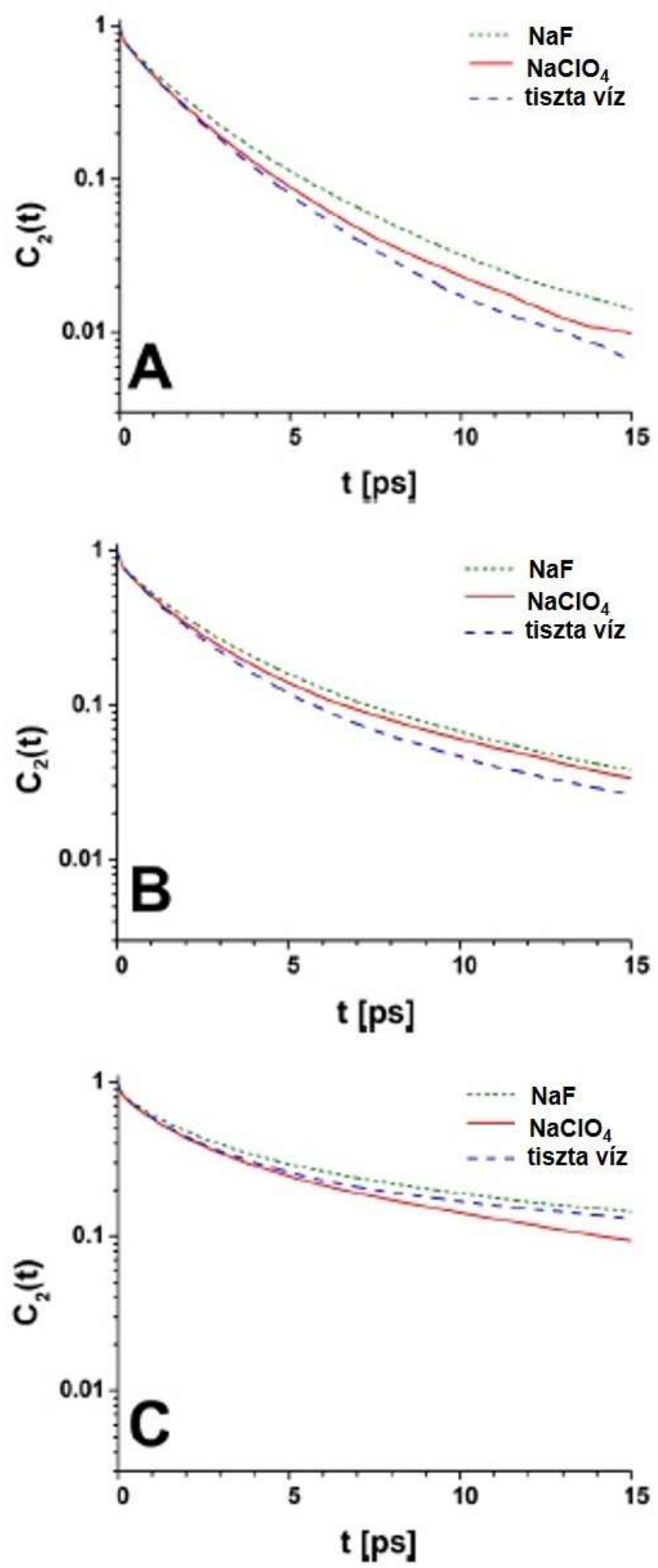

28. ábra A tc5b minifehérje első hidratációs burkában található vízmolekulák orientációs autokorrelációs függvényei a 25. ábrán megadott energia intervallumokban: (A) $E_{1}$, (B) $E_{2}$ és (C) $E_{3}$ a tiszta vizes esetben, továbbá a $\mathrm{NaF}$ és $\mathrm{NaClO}_{4}$ sók jelenlétében. 
Az $E_{1}, E_{2}$ és $E_{3}$ intervallumok szerint felosztva az első hidratációs burok vízmolekuláit, meghatároztuk mindegyik csoportra az orientációs autokorrelációs függvényeket (28. ábra). Megállapítható, hogy a gyengén $\left(E_{1}\right)$ és közepesen kötött $\left(E_{2}\right)$ vízmolekulákat tekintve mindkét só lassította a reorintációt a tiszta vizes rendszer eredményeihez hasonlítva (28.A-B ábra). A lassítás nagyobb mértékü a kozmotróp anionok jelenlétében, mint a kaotrópok esetében. Mindazonáltal a legerősebben kötött $\left(E_{3}\right)$ vízmolekulákra HS szerinti rendezettség mutatkozik az autokorrelációs függvények között, azaz a kaotróp ionok gyorsítják, míg a kozmotrópok lassítják reorientációs dinamikát a tiszta vizes rendszerhez képest (28.C ábra). A korábbi megállapításunkat, ami szerint a pozitívan töltött csoportok közelében a perklorát ionok gyorsítják, a fluorid ionok pedig lassítják a vízmolekulák orientációs dinamikáját a tiszta vizes esethez képest annyiban finomíthatjuk, hogy ez a tulajdonság a legerősebben kötött ( $E_{3}$ régióba tartozó) vízmolekulákra igaz.

A fentiekben megvizsgáltuk a vízmolekulák szerepét a minifehérje és a hidratációs környezete közötti kölcsönhatási energia tekintetében (21.B ábra). A vizsgált leginkább kozmotróp és kaotróp hatású anionok jelenlétében a vízmolekulák minifehérjével vett kölcsönhatási energiája csökken, a $\mathrm{ClO}_{4}{ }^{-}$esetében a csökkenés jelentősebb. Ezek a változások két okra vezethetőek vissza. Egyfelöl a CP-típusú kölcsönhatások következtében vízmolekulák szorulnak ki a fehérje-víz határfelületről, másfelől az ionok jelenléte a határfelületen és annak közelében átrendezi a felszínközeli vízszerkezetet és megváltoztatja a lokális hidratációs tulajdonságokat. Ez az átrendezés kevésbé kedvező, vagy kedvezőtlen fehérje-víz kölcsönhatásokhoz vezethet. Az utóbbi eset a 26. ábrán nyilvánul meg, mégpedig a pozitív kölcsönhatási energiával rendelkező vízmolekulák számának növekedésében. Az ebbe a régióba tartozó vízmolekulák száma rendre 1,67 és 2,21 a $\mathrm{NaClO}_{4}$ és $\mathrm{NaF}$ sókat tartalmazó rendszerekben.

Több szerző is felhívta a figyelmet, hogy az oldott ionok kölcsönhatásait tekintve a kvantummechanikai effektusok fontos szerepet játszanak [83-87]. Ezért megjegyzendő, hogy egy kvantitatív eredményeket szolgáltató modellnek kezelnie kell ezeket az effektusokat. Mindazonáltal, ez a klasszikus modell is alkalmas a kísérleti tapasztalatokkal összhangban lévő eredmények származtatására, melyek felhasználásával az ionokhoz köthető hatások kvalitatív módon leírhatók, és segítségükkel megvizsgálhatóak a lehetséges atomi mechanizmusok.

\subsubsection{Az ionok és a fehérje felszíni hidratációja [P3]}

A korábbi fejezetekben rögzített minifehérje-geometria mellett tanulmányoztuk a határfelület tulajdonságait, mint például az ionok eloszlását a fehérje-víz határfelületen illetve a fehérjeközeli vízmolekulák reorientációs tulajdonságait. Emellett REMD szimulációk segítségével határoztuk meg a tc5b ionok hatására bekövetkezett stabilitás változásait.

Mindazonáltal a fehérje és ionok további hidratációs tulajdonságainak vizsgálatával és harmonikus kényszerek szerepének azonosításával további megállapítások tehetők, melyek a HE hatásmechanizmusának a feltérképezésében jelentősek. Ennek érdekében helyezzük új kontextusba az eddigi szimulációkat. Amikor harmonikus kényszerek segítségével fixáljuk a protein (NMR adatokból származó) térszerkezetét akkor egy mesterséges állapotot hozunk 
létre. Ebben az esetben a jelentős másodlagos és harmadlagos szerkezeti változások megakadályozásával, és az oldalláncok mozgásának zavaró hatásait kiküszöbölve vizsgálhatjuk egy egyensúlyi ioneloszlás kialakulását a fehérje-víz határfelületen. Ezt az állapotot fogjuk a továbbiakban felhalmozódási szakasznak nevezni. A harmonikus kényszerek elhagyásával és ebből következően a minifehérje szabad mozgása által a tc5b reagálhat a megváltozott hidratációs környezetre, így szerkezeti és stabilitási változások lépnek fel, ez az átrendeződési állapot. A két állapot között megváltozik mind a minifehérje, mind az oldott ionok szolvatációja. Azonban az ionok és a minifehérje oldódását nemcsak a kényszerek megléte befolyásolja, hanem mindkét szereplö egyidejü jelenléte a szimulációs rendszerben. Annak érdekében, hogy mindezen hatásokat szétválaszthassuk a következő szimulációkat fogjuk használni:

1) 100 ns hosszúságú NPT szimuláció a minifehérje nélkül, ahol mindkét vizsgált só 1 mólos koncentrációban van jelen, külön szimulációs rendszerekben. Ezen szimulációk segítségével megvizsgálhatjuk az egyes ionok hidratációs tulajdonságait.

2) 100 ns hosszúságú NPT szimuláció, a releváns molekuladinamikai beállítások változatlansága mellett csak a minifehérjével és minimális számú, semlegességet biztosító ionokkal tiszta vízben feloldva. Ez szintén egy referencia rendszer lesz azokra az esetekre, amikor a minifehérje és a nagy koncentrációjú ionok egyaránt jelen vannak.

3) Felhalmozódási szakasz. 100 ns hosszúságú NPT szimuláció, mely során a minifehérje és az ionok egyszerre vannak jelen a szimulációs rendszerben, ugyanazokkal a molekuladinamikai beállításokkal, de a tc5b-re harmonikus kényszerek vonatkoznak. Ezen szimulációk segítségével megvizsgáljuk az ionok és a minifehérje szolvatációban mutatott eltéréseit az előző rendszerekhez viszonyítva. Ezek a változások a fehérje-víz határfelületi anizotrop töltéseloszlások következményei, de a minifehérje konformációs változásai nem játszanak szerepet.

4) Átrendeződési szakasz. Ez esetben is az előzőleg alkalmazott szimulációs rendszereket használjuk a harmonikus kényszerek nélkül. A megfelelő mintavételezés érdekében a 32 szálas REMD számolás 300 K-es replikájának utolsó 300 ns-át használjuk az NPT dinamika helyett. Ez a szimuláció lehetővé teszi a minfehérje szerkezeti változásából eredő változások feltérképezését. 


\subsubsection{A perklorát ionok hidratációja és a felületi geometria [P3]}

A minifehérje-ion kölcsönhatási energia eloszlását és a fellépő kölcsönhatás típusokat részletesen megvizsgáltuk eltérő tulajdonságú határfelületi elemek környezetében (21,23-25 ábrák). A minifehérje helyett az egyes ionokat tekintve, megvizsgálhatjuk a $\mathrm{ClO}_{4}^{-}$ionok hidratációs, pontosabban dehidratációs jellemzőit a határfelületi felszín elemek sajátságainak függvényében az 1-es és a 3-as szimuláció összehasonlításával, azaz a felhalmozódási szakaszba történő átmenet során. Ennek érdekében meghatároztuk a perklorát ionok első hidratációs burkaiban található vízmolekulák átlagos számát az összes korábban vizsgált esetben. A tc5b és az anion kölcsönhatását jellemző számolás csak azokra az anionokra vonatkozott, melyek 0,4 nm-nél közelebb voltak a vizsgált atomcsoport nehéz atomjaihoz. A perklorát ionok első hidratációs burkának a határát $(0,50 \mathrm{~nm}$ a központi $\mathrm{Cl}$ atomtól) a referenciaként használt, csak ionokat tartalmazó rendszerből származtattuk (ld. Függelék 1F. táblázat) az anion körüli víz-oxigén atomok RDF-je segítségével, ahogy ez a tc5b esetében is történt.

Az oldószernek kitett, töltött oldallánccal rendelkező $\mathrm{Arg}^{16}$ és Lys ${ }^{8}$ aminosavak esetében a CP típusú kölcsönhatásban résztvevő perklorát ionok első hidratációs burkában átlagosan, rendre 6,46 és 6,40 vízmolekula található. Ez az érték lényegesen kisebb az $\mathrm{N}$-terminálison található $\mathrm{NH}_{3}{ }^{+}$csoport környezetében, ahol is: 4,66. A csökkenés az N-terminálon kezdődő $\alpha$-hélix miatt létrejött felületi mélyedés következménye, melyben található $\mathrm{NH}$ csoport is, amivel szintén kölcsönhatásba lép a perklorát ion, ezáltal még több vízmolekulát veszítve az első hidratációs burkából (29. ábrán felül). Ugyanakkor az összes protonált helyen a vízmolekulák által közvetített kölcsönhatások a preferáltak a $\mathrm{F}^{-}$ionok esetében, ami azt jelenti, hogy a kozmotróp ionok részben, vagy egészben megőrzik a hidratációs burkukat (29. ábrán alul). Az Nterminálison található $\mathrm{NH}_{3}{ }^{+}$csoport esetén a CP típusú kölcsönhatások elhanyagolható aránnyal rendelkeznek a $\mathrm{F}^{-}$ion esetében, csakúgy, mint az alacsonyabb parciális töltésü atomok alkotta kölcsönhatási helyeken. Ezekben az esetekben ugyanis a kozmotróp ionoknak a hidratációs burkuknak túl nagy részét kellene elhagyniuk egy CP típusú kölcsönhatás formálásához. 

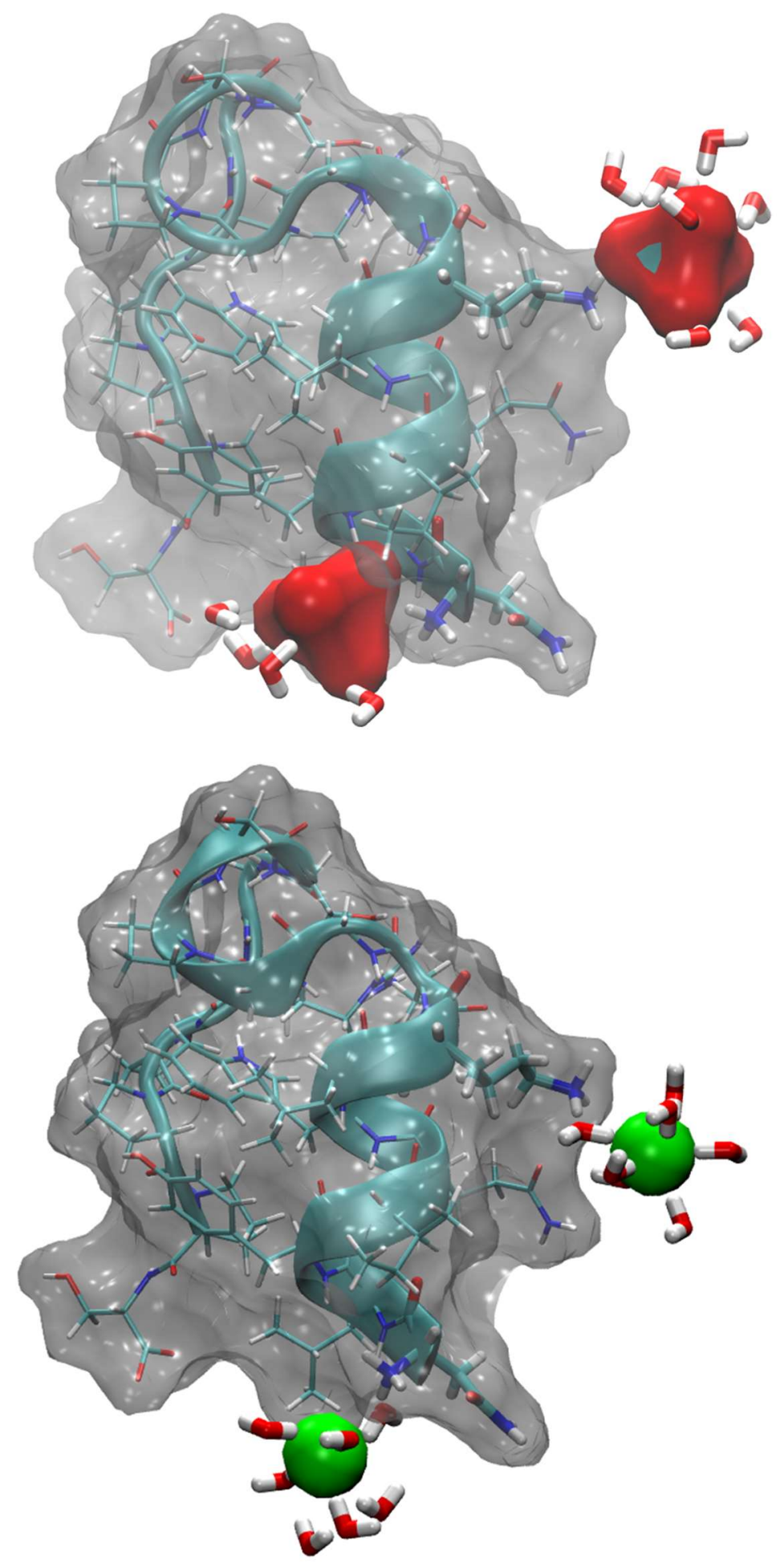

29. ábra $\mathrm{A}$ tc5b-vel $\mathrm{CP}$ típusú kölcsönhatásban lévő $\mathrm{ClO}_{4}{ }^{-}$ionok és $\mathrm{SSP}$ típusú kölcsönhatásban a $\mathrm{F}^{-}$ ionok és az első hidratációs burkukban található vízmolekulák a víznek kitett, töltött oldallánccal rendelkező Lys ${ }^{8}$ aminosav és az N-terminálison található $\mathrm{NH}_{3}{ }^{+}$csoport esetében.

A fölánc NH csoportok és a Pro ${ }^{12}$ aminosav oldallánc esetében a perklorát ionok első hidratációs burkában az átlagos vízszám rendre 6,07 és 6,25. Ezekben az esetekben a kaotróp anionok ,sekélyebb” mélyedésekben találhatóak. 


\subsubsection{Vízmolekulák száma az első hidratációs burkokban [P3]}

A 3. táblázat tartalmazza az ionok és a minifehérje első hidratációs burkában található átlagos vízszámok referencia értékeit, illetve ezek változásait az egyes szakaszok közötti átmenetek során.

\begin{tabular}{|c|c|c|c|c|c|}
\hline & 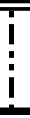 & Referencia & $\begin{array}{c}\text { Felhalmozódási } \\
\text { állapot }\end{array}$ & $\begin{array}{c}\text { Átrendeződési } \\
\text { állapot }\end{array}$ & Teljes változás \\
\hline $\mathrm{NaF}$ & 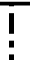 & & & & \\
\hline minifehérje & ! & 99,2 & $-1,3$ & $-1,2$ & $-2,5$ \\
\hline $\mathrm{F}^{-}$ & $!$ & 279,9 & $-8,9$ & 1,2 & $-7,7$ \\
\hline $\mathrm{Na}^{+}$ & 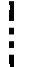 & 247,0 & $-2,4$ & 0,1 & $-2,3$ \\
\hline$\overline{\mathrm{NaClO}} 4$ & i & & & & \\
\hline minifehérje & 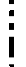 & 99,2 & $-12,8$ & $+4,8$ & $-8,0$ \\
\hline $\mathrm{ClO}_{4}^{-}$ & 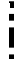 & 637,2 & $-21,5$ & $-12,4$ & $-33,9$ \\
\hline $\mathrm{Na}^{+}$ & 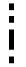 & 247,8 & $-1,9$ & $-4,9$ & $-6,8$ \\
\hline
\end{tabular}

3. táblázat Vízmolekulák száma az ionok és a minifehérje első hidratációs burkában a referencia rendszerre (2. oszlop). Az átlagos vízszám változás a referencia rendszer és felhalmozódási szakasz között (3. oszlop), a felhalmozódási- és az átrendeződési szakaszok között (4. oszlop) és a teljes folyamat során az összesített változás (5. oszlop).

A táblázat második oszlopában az ionok és minifehérje első hidratációs burkának átlagos vízszámait tüntettük fel, abban az esetben, amikor külön-külön vannak feloldva (1-es és 2-es szimulációk). A harmadik és negyedik oszlopban rendre a referenciarendszerekből a felhalmozódási szakaszba, majd onnan az átrendeződési szakaszba történő átmenetek során fellépő átlagos vízszám-változások láthatók, valamint az ötödik oszlop mutatja a két átmenet összesített átlagos vízszám-változását. A vizsgált ionok első hidratációs burkainak határait a referenciaként használt 1 mólos sóoldatot tartalmazó szimulációs rendszerből származtattuk, hasonló módon, mint a minifehérje esetében, az adott molekula körüli víz-oxigén atomokra vonatkozó RDF alapján (ld. Függelék 1F. ábra, 1F. táblázat).

A fluorid ion esetén az átlagos vízszám-változások relatíve kicsinyek a felhalmozódási szakaszba történő átmenet során. A miniprotein első hidratációs burkában az átlagos vízszám 1,3-es csökkenést mutat, míg a kationok és anionok rendre 2,4 és 8,9 vízmolekulát veszítenek az első hidratációs burkukból átlagosan. A fehérjeszerkezetre vonatkozó kényszerek elhagyása után további 1,2 átlagos vízszám-veszteséget okoz a tc $5 \mathrm{~b}$ esetében, a $\mathrm{Na}^{+}$ionok első hidratációs burkának átlagos vízszáma gyakorlatilag változatlan, a $\mathrm{F}^{-}$ionok körül pedig átlagosan 1,2 vízmolekulával növekszik az átlagos vízszám.

A perklorát ionok jelenlétében szignifikánsabb változások tapasztalhatók a teljes rendszer hidratációs tulajdonságait tekintve. A miniprotein első hidratációs burkában lévő vízmolekulák összesített száma átlagosan 12,8-al csökken a felhalmozódási szakaszba történő átmenet során, 
ez az érték a perklorát ionok esetében 20,8, a nátrium ionok esetében pedig 1,9. Az átrendeződési szakaszban további 4,9 és 13,4 értékü átlagos vízszám-csökkenés figyelhető meg rendre a $\mathrm{Na}^{+}$és a $\mathrm{ClO}_{4}{ }^{-}$ionok esetében.

\subsubsection{Az első hidratációs burkok átfedései [P3]}

A fentiek alapján a két ellentétes hatású Hofmeister-aktív anion különböző módon lép kölcsönhatásba a határfelületi vízmolekulákkal. Ez a tulajdonság megnyilvánul még az ionok és a minifehérje első hidratációs burkainak átfedése közötti különbségekben is. A perklorát iont tartalmazó szimulációs rendszerben átlagosan 29,3 $(33,4)$ és 5,5 $(5,2)$ vízmolekula kerül átfedésbe az első hidratációs burkokban rendre a $\mathrm{ClO}_{4}{ }^{-}$és $\mathrm{Na}^{+}$ionok esetében, a minifehérjére vonatkozó harmonikus kényszerekkel (kényszerek nélkül). A fehérje-víz határfelületen nagy számban halmozódnak fel $\mathrm{ClO}_{4}^{-}$ionok, ezért a felszín közeli vízmolekulák részben reorientáltak.

A minifehérje és az oldott $\mathrm{NaF}$ só esetében az első hidratációs burkok átfedéséhez tartozó értékek rendre 6,5 $(6,2)$ a fluorid ionra és 5,3 $(5,5)$ a nátrium ionra. A F $\mathrm{F}^{-}$ionok jellemzően nem halmozódnak fel a fehérje-víz határfelületen, azonban a szimulációs rendszerben jelenlévő elemek közül a legerősebben hidratáltak közé tartoznak, azaz legalább két jól elkülöníthető hidratációs burokkal rendelkeznek (ld. Függelék 1F. ábra). Ezekben a hidratációs burkokban a vízmolekulák erősen orientáltak, és a reorientációs dinamikájuk is jellemzően lassabb, összevetve a többi vizsgált ionhoz tartozó eredményekkel.

\subsection{Az ionfelhalmozódás lokális jellemzői és kapcsolatuk az aminosav oldalláncok térbeli fluktuációihoz [P2]}

A REMD szimulációk 300-360 K közötti dinamikáit felhasználva kiszámítottuk a perklorát és fluorid ionok átlagos számát (30.A1-A2 ábra) és a hozzá tartozó fluktuációkat (30.B1-B2 ábra) a minifehérje első hidratációs burkában külön minden aminosav esetében. A 30.A1-A2 ábra alapján megállapítható, hogy mindkét vizsgált Hofmeister-aktív anion a pozitívan töltött oldalláncok környezetében halmozódnak fel, azonban jelentősen eltérő mértékben. A perklorát ionok felhalmozódása kitüntetett az Asn ${ }^{1}$ aminosavnál, ami a töltött N-terminálison található, ahol az $\alpha$-hélix a jellemző másodlagos szerkezet, és az $\operatorname{Arg}^{16}$ aminosavnál, ami a tc5b sóhídjának egyik alkotója. Azonban, a $300 \mathrm{~K}$ hőmérséklethez tartozó dinamikát tekintve a Lys ${ }^{8}$ esetén a legnagyobb az átlagos anion szám. A fehérje-víz határfelületen a fluorid ionok átlagos száma a 0,15-0,32 értékek közötti sávban változik, míg a perklorát ionok esetén a minimum érték 1,0, a maximum pedig 2,3. Továbbá, az átlagos fluorid ion szám szinte független a hőmérséklettől a vizsgált 300-360 K intervallumban (30.A2 ábra). Ezzel ellentétben, a perklorát ionok átlagos száma folyamatosan csökken a hömérséklet növelésével és az egyes aminosavak közötti különbségek a kaotróp anion felhalmozódást tekintve fokozatosan eltünnek a $360 \mathrm{~K}$ hőmérséklet közelében (30.A1 ábra). A relatív ionszám-fluktuáció (30.B1-B2 ábra) a fluorid ion esetében mérsékeltek a kitüntetett felhalmozódási helyeken is, míg a perklorát ionok esetében a nagyobb ionszám egy adott aminosav körül nagyobb fluktuációt is indukál. 

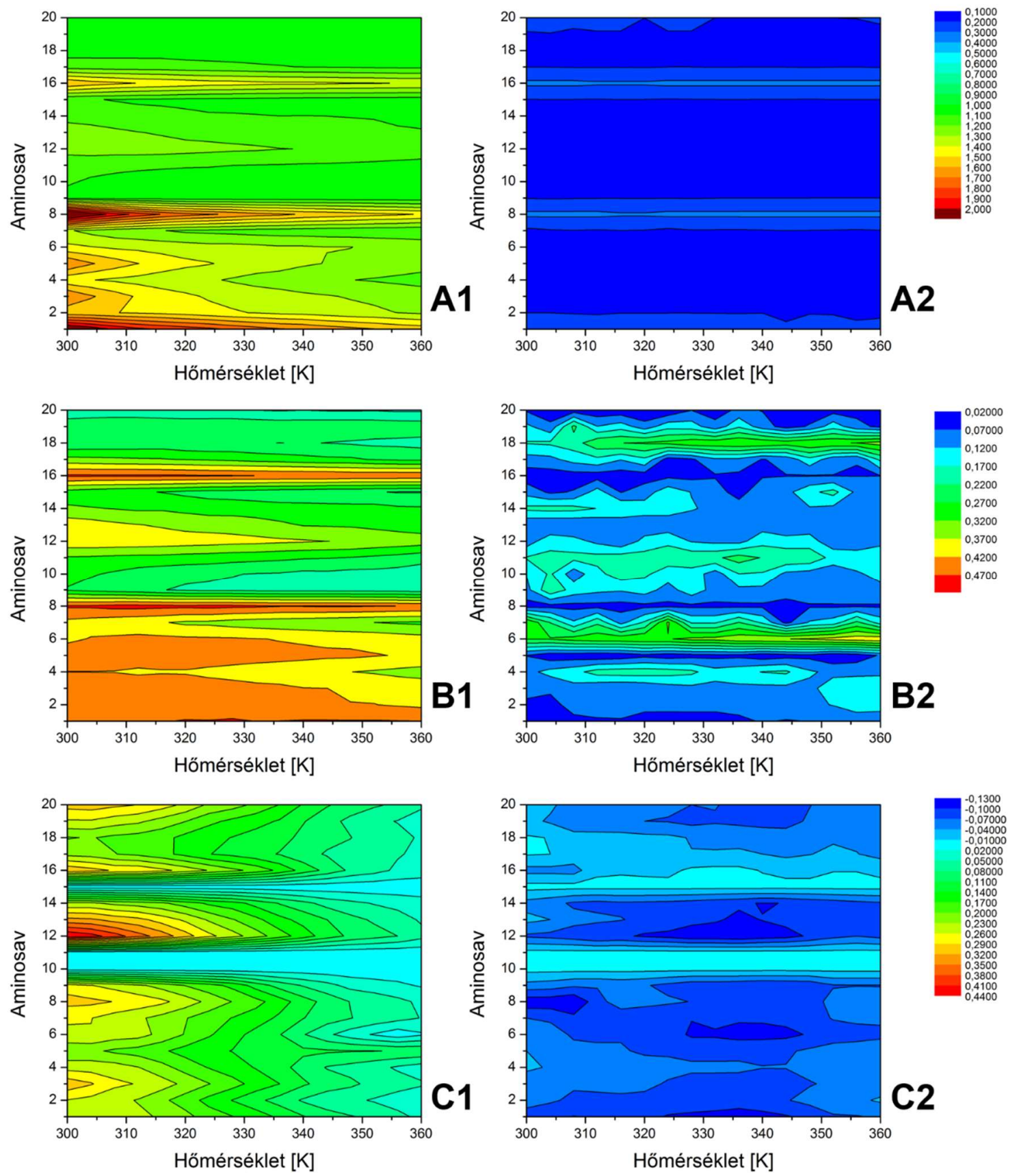

30. ábra Átlagos ionszám a minifehérje-víz határfelületen a $\mathrm{NaClO}_{4}$ (A1) és $\mathrm{NaF}$ (A2) sókat tartalmazó rendszerekre. A (B1) és (B2) ábrák rendre az ezekhez a rendszerekhez tartozó ion szám fluktuációk. Oldallánc nehézatom RMSF különbségek a tiszta vizes esetet használva referenciának a $\mathrm{NaClO}_{4}(\mathrm{C} 1)$ és $\mathrm{NaF}(\mathrm{C} 2)$ sók jelenlétében. Mivel csak az oldallánc nehézatomokat vesszük figyelembe a Gly ${ }^{10}$, Gly $^{11}$ és Gly ${ }^{15}$ aminosavak esetén az RMSF nem értelmezhető.

A Hofmeister-aktív ionok térszerkezeti stabilitásra gyakorolt hatását az oldallánc atomok átlagszerkezet körüli térbeli fluktuációival (RMSF) jellemezzük, külön minden aminosav esetén. A 30.C1-C2 ábrán láthatjuk az RMSF különbségeket a tiszta vizes esethez viszonyítva. Megállapítható, hogy a kaotróp $\mathrm{ClO}_{4}^{-}$ionok növelik az oldalláncok térbeli fluktuációit (30.C1 
ábra), míg a kozmotróp $\mathrm{F}^{-}$jelenlétében ezek a fluktuációk csökkennek (30.C2 ábra) minden aminosav esetén. Ugyanakkor a hőmérséklet növelésével a tiszta vizes és a perklorát iont tartalmazó rendszerek közötti RMSF különbség csökken a teljes szekvencia mentén, hasonló módon az átlagos ionszámhoz (30.A1 ábra). A F $\mathrm{F}^{-}$ion jelenlétében pedig ez a tulajdonság nem jellemző, szinte változatlan az RMSF különbség a vizsgált 300-360 K hőmérsékleti tartományban, szintén az átlagos ionszámhoz hasonló módon (30.A2 ábra).

A 30. ábrán bemutatott átlagos értékek és a hozzájuk tartozó fluktuációk összhangban vannak az azonosított ion-fehérje kölcsönhatási tulajdonságokkal. A közvetlen ion-fehérje kapcsolat elkerülésével a $\mathrm{F}^{-}$ionok jellemzően megőrzik az első hidratációs burkukat, így még a pozitívan töltött oldalláncok esetén is mérsékelt a felhalmozódásuk, perklorát ionok jelenlétében ellentétes tulajdonságokról beszélhetünk, a teljes 300-360 K hőmérsékleti tartományban. A határfelületi felhalmozódási különbségek mellett a két Hofmeister-aktív ion ellentétes fluktuációs jellemzőkkel is rendelkezik. Ezek a tulajdonságok szoros korrelációban vannak a térbeli stabilitás leírására választott mennyiséggel, az oldallánc nehézatomok RMSF értékeivel. A két vizsgált anion a HS-ban elfoglalt helyüknek megfelelően növelték $\left(\mathrm{ClO}_{4}{ }^{-}\right)$, vagy csökkentették ( $\left.\mathrm{F}^{-}\right)$az RMSF-et a tiszta vizes rendszerhez viszonyítva. Ésszerü feltételezni, hogy mindezek alapvetően befolyásolják a SASA változásokat (11. ábra) és azon keresztül $\Delta \gamma$-t is (12. ábra).

\subsection{A HE értelmezése mikroszkopikus szinten}

Az eddig bemutatott eredményeket felhasználva a tc $5 b$ minifehérje kozmotróp stabilizációja és a kaotróp destabilizációja során fellépő atomi mechanizmusok azonosíthatóak. Ezeket külön szekciókban tekintjük át.

\subsubsection{Kaotróp destabilizáció [P3]}

Jellemzően a kaotróp anionok felhalmozódnak a fehérjefelszínen (16. ábra) és általában CPtípusú kölcsönhatást alakítanak ki a minifehérjével (24-25 Ábrák). Ugyanakkor a perklorát ionok kevésbé erős kölcsönhatásba lépnek a vízmolekulákkal, mint akár a vízmolekulák egymással (1F. ábra). Ezt a két tulajdonságot szem elött tartva vizsgáltuk meg a hidratációs változásokat mind a minifehérje, mind a perklorát ionok tekintetében.

A kaotróp destabilizálódás során a határfelületen felhalmozódó perklorát ionok részben destabilizáljak a határfelületi víz szerkezetet. Másfelől pedig jelentős dehidráció tapasztalható mind a minifehérje, mind a perklorát ionok esetében, ami egy jelentős eltérés a $\mathrm{F}^{-}$ionokat tartalmazó rendszerekhez képest. A felhalmozódási szakaszban, egyfelől a minifehérje első hidratációs burkában kevesebb vízmolekula található, másrészt a vízmolekulák egy jelentős része a kaotróp ionok jelenléte miatt reorientálódik, összességében csökkentve a fehérje-víz kölcsönhatás nagyságát (21. ábra). Emellett a vízmolekulák közötti H-híd kötés rendszer erőssége is csökken (20. ábra, 28. ábra), főleg a legerősebben kötött, szerkezetstabilizáló vízmolekulák esetében. A kevésbé merev vízszerkezet viszont könnyebbé teszi a térszerkezet 
meglazulását, aminek a hatását az átrendeződési szakaszban vizsgálhatjuk. A vízmolekulákra jellemző változások ellenére tc $5 \mathrm{~b}$ és a teljes hidratációs környezet közötti kölcsönhatás viszont összességében növekszik (21. ábra). Ez viszont szintén a szerkezeti stabilitás csökkenését vonja maga után, ami összhangban van kísérleti tényekkel és az eredményeinkkel (11. ábra).

A dehidráció mértékét bemutattuk a felhalmozódási szakaszban. Ugyanakkor a felhalmozódási szakaszból az átrendeződési szakaszba történő átmenet során a minifehérje első hidratációs burkában átlagosan 4,8-as növekedés történik az átlagos vízszám tekintetében. Ez a növekedés a kevésbé stabil térszerkezetnek és az ebből adódó megnövekedett SASA-nak a következménye (11. ábra). A megnövekedett SASA ellenére, összességében, a tiszta vizes esettel összehasonlítva kevesebb vízmolekula található a tc $5 \mathrm{~b}$ első hidratációs burkában (3. táblázat). A fehérje-víz határfelületen gyengén kötött vízmolekulák, melyek mind a tc5b, mind a felület közeli perklorátok első hidratációs burkában is lehetnek, jelentős része a tömbfázisba kerül.

A hidratációs tulajdonságok változása összhangban van a minifehérje perklorát ion esetében megfigyelt CP-típusú kölcsönhatás-preferálásában. Ez a kölcsönhatás típus a teljes minifehérje esetében és a külön-külön vizsgált kölcsönhatási helyeken is megfigyelhető (23-25 ábra). Aminek a következménye, hogy a minifehérje töltött, és kisebb pozitív parciális töltéssel rendelkező felületei környezetében megnövekszik a konformációs fluktuáció (30. ábra), ami teret enged a kaotróp anion további dehidratációjának a megnövekedett fehérje-víz határfelületen (11. ábra). Ezt a dehidratáció lehet a kaotróp destabilizáció legfontosabb hajtó ereje.

Továbbá, a tc5b azon felületelemei környezetében a legjellemzőbb a CP-típusú kölcsönhatás, ahol megnövekszik a perklorát ion felhalmozódása, és ugyanakkor ezekben a régiókban jelentkezik először a jelentősen megnövekedett oldallánc-fluktuáció, ahogy ezt a 30. ábra is mutatja. A magasabb hőmérsékleten csökken a határfelületen található perklorát ionok átlagos száma, valószínűleg a hőmozgás következtében, azonban még 360 K-en is jelentősen meghaladja a $\mathrm{F}^{-}$ionokhoz tartozó értékeket. Mindemellett, $360 \mathrm{~K}$-en a perklorát ionokat tartalmazó rendszer konformációs sokasága már szinte csak szétesett konformációkat tartalmaz, amit a megnövekedett SASA (11. ábra) is jelez.

\subsubsection{Kozmotróp stabilizáció [P3]}

A kozmotróp fluorid ionok rendkívül erős első- és egy jól meghatározott második hidratációs burokkal rendelkeznek (1F. ábra). Ezek a hidratációs burkok átfednek a tc5b minifehérje saját hidratációs burkával, ezt a jelenséget a 6.4.6.3 szakaszban vizsgáltuk meg. Összevetve a perklorát ionokat tartalmazó rendszerrel, ezek a vízmolekulák (és minden bizonnyal a kozmotróp ion második hidratációs burkába tartozók is) erősebben vannak kötve az anionokhoz. Ez viszont a tc5b első hidratációs burkát (kiemelten azoknál a kölcsönhatási helyeknél, ahol a $\mathrm{F}^{-}$ion is megtalálható) merevebbé teszi. A fehérje-ion kölcsönhatást tekintve a $\mathrm{F}^{-}$ion nehezen alakít ki közvetlen kölcsönhatást a minifehérjével, a vízmolekulák által közvetített SSP és 2SP típusú kölcsönhatások azonban nagyobb valószínüséggel alakulnak ki (23-24. ábra). Tehát sokkal jellemzőbb, hogy az ion az erősen rendezett hidratációs burkán 
keresztül lép kölcsönhatásba a fehérjével, ami egyrészt még lassúbbá teszi a határfelületi vízmolekulák reorientációját (20. ábra, 28. ábra), másrészt pedig olyan módon rendezi ezeket a vízmolekulákat, hogy a minifehérjével kedvezötlen lesz a kölcsönhatásuk (26. ábra), csökkentve ezzel a tc5b és vízmolekulák közötti csatolást (21. ábra). Végezetül pedig a minifehérje és a környezete közötti kölcsönhatási energia csökken, ami a térszerkezet stabilizálódását jelzi [147]. Ami a határfelületi feszültség koncepció tekintetében kisebb átlagos SASA értékeket jelent (11. ábra) a tiszta vizes esettel összehasonlítva és pozitív előjelű $\Delta \gamma-\mathrm{t}$ eredményez (12. ábra). Azonban megjegyzendő, hogy a több atomból álló kozmotróp anionok másként is viselkedhetnek. Ebben az esetben elképzelhető, hogy nagyobb affinitással rendelkezhetnek a fehérje pozitívan töltött részeivel létrejövő közvetlen kölcsönhatásra, minek következtében több erősen kötött vízmolekulát vesztenek az első hidratációs burkukból. Egyéb határfelületi régiókban viszont valószínűleg ugyanolyan hidratációs- és kölcsönhatási tulajdonságokat tapasztalhatunk, mint a $\mathrm{F}^{-}$ion esetében megfigyelhető [73, 148]. Mindemellett, - ellentétben a kaotróp destabilizációval - sem a felhalmozódási-, sem az átrendeződési szakaszban nem tapasztalható jelentős változás sem az ionok, sem a minifehérje első hidratációs burkában található vízmolekulák átlagos számában (3. táblázat). Vagyis ebben az esetben nem történik számottevő dehidratáció és nincs számottevő szerkezeti változás sem. A 30. ábrán bemutatott eredmények szerint a fluorid ionok tc5b-vel történő kölcsönhatási tulajdonságai a 300-360 K-es hőmérsékleti sávban javarészt változatlanok, így ez a stabilizációs mechanizmus nem csak $300 \mathrm{~K}$-en jellemzö.

\subsection{Helicitás, szerkezeti stabilitás, intramolekuláris kölcsönhatások}

Megvizsgáltuk, hogy a kaortóp destabilizáció és a kozmotróp stabilizáció során milyen szerkezeti változások jelentkeznek, illetve hogyan változik a tc5b-re jellemző másodlagos szerkezeti elemek jelenléte a hőmérséklet függvényében. Ahogy azt a korábbi szekciókban bemutattuk, az azonosított SASA és a felületi feszültség változások mind konzisztensek voltak a határfelületi feszültség koncepcióval. Mindazonáltal a SASA-változások több párhuzamosan játszódó folyamat közös eredményei. A tc5b konformációját tekintve, ezek elsősorban a helikális tartalom változása a tiszta vizes esethez képest a két ellentétes hatású Hofmeister-aktív ion hozzáadásakor, továbbá a hidrofób kölcsönhatások és a sóhíd stabilizálódása, vagy felbomlása.

A REMD szimulációk 300-360 K közötti hőmérsékleti tartományban kiszámítottuk az átlagos, és aminosavankénti helicitást a fölánc megfelelő $(\phi, \psi)$ szögpárjait használva, a $310^{-}$és az $\alpha-$ hélixekhez tartozó szokásos definíciók mellett (melyek rendre $\left(-60^{\circ},-30^{\circ}\right)$ és $\left.\left(-60^{\circ},-50^{\circ}\right)\right), 30^{\circ}-$ os eltérést megengedve. 

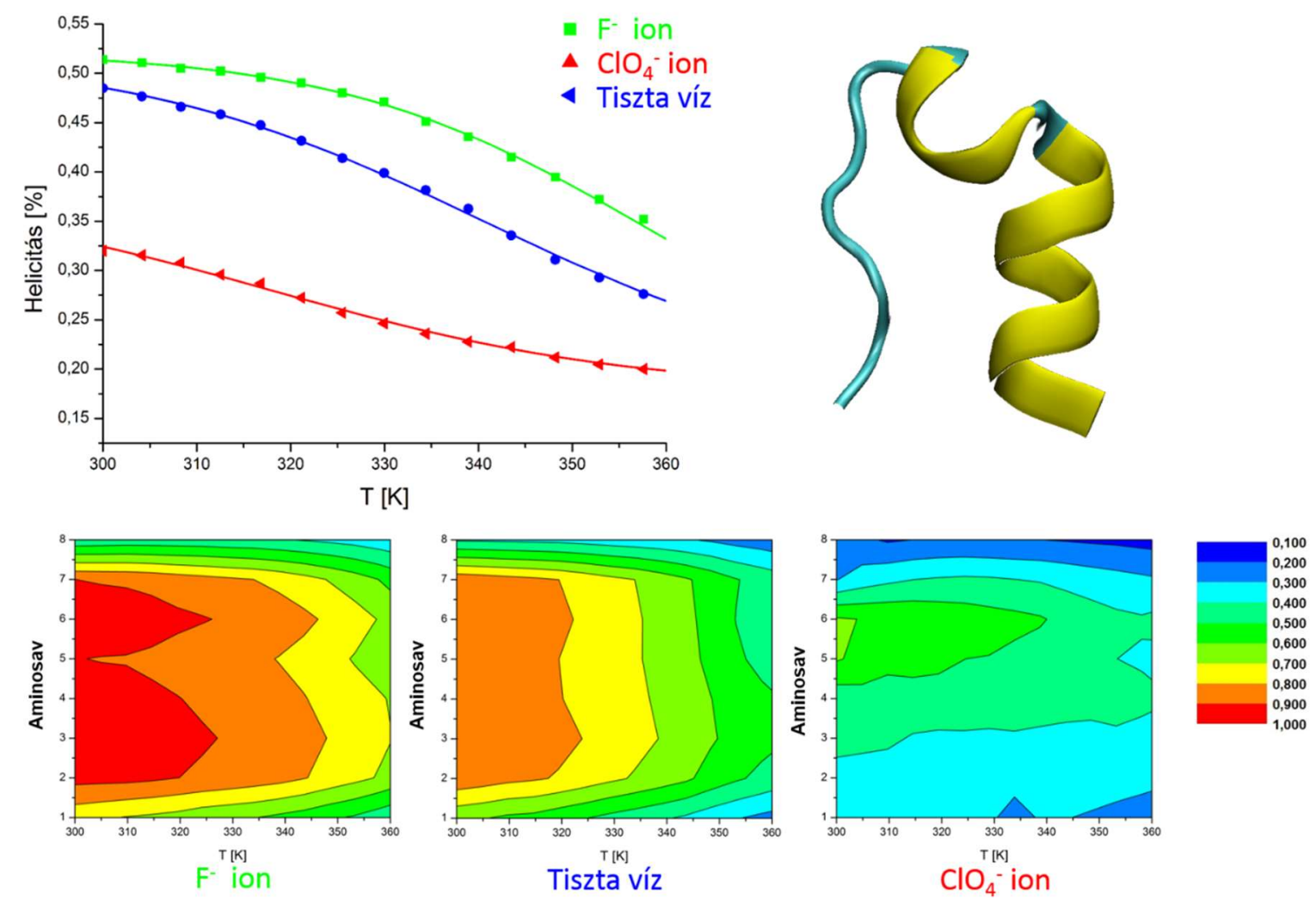

31. ábra A REMD szimulációk során számolt helicitás hőmérsékletfüggése (felül) és aminosavankénti helicitás értékek (alul).

A helikális tartalmat illetően (31. ábra) látható, hogy a vizsgált hömérsékleti tartományban a $\mathrm{F}^{-}$ ionok jelenléte az összes konformációs sokaság esetén magasabb értéket eredményezett összevetve a tiszta vizes esettel, míg a $\mathrm{ClO}_{4}^{-}$ionok ellentétes hatást váltottak ki. Az aminosavankénti értékeket tekintve pedig megállapítható, hogy a helikális szegmens felbomlása pontosan azoknál az aminosavaknál kezdődött (már 300 K-en), ahol jelentős perklorát-felhalmozódást és közvetlen, $\mathrm{CP}$ típusú kölcsönhatást azonosítottunk. A F- ionok stabilizáló hatása pedig a teljes helikális szegmensre kiterjed, anélkül, hogy jelentősen felhalmozódnának a határfelületen, összhangban a fent javasolt HE értelmezéssel. Ugyanis ebben az esetben a központi körülmény a vízszerkezet megerösítése a határfelületen, ezáltal késleltetve a vizsgált másodlagos szerkezeti elemek hőmérsékleti destabilizációját. 

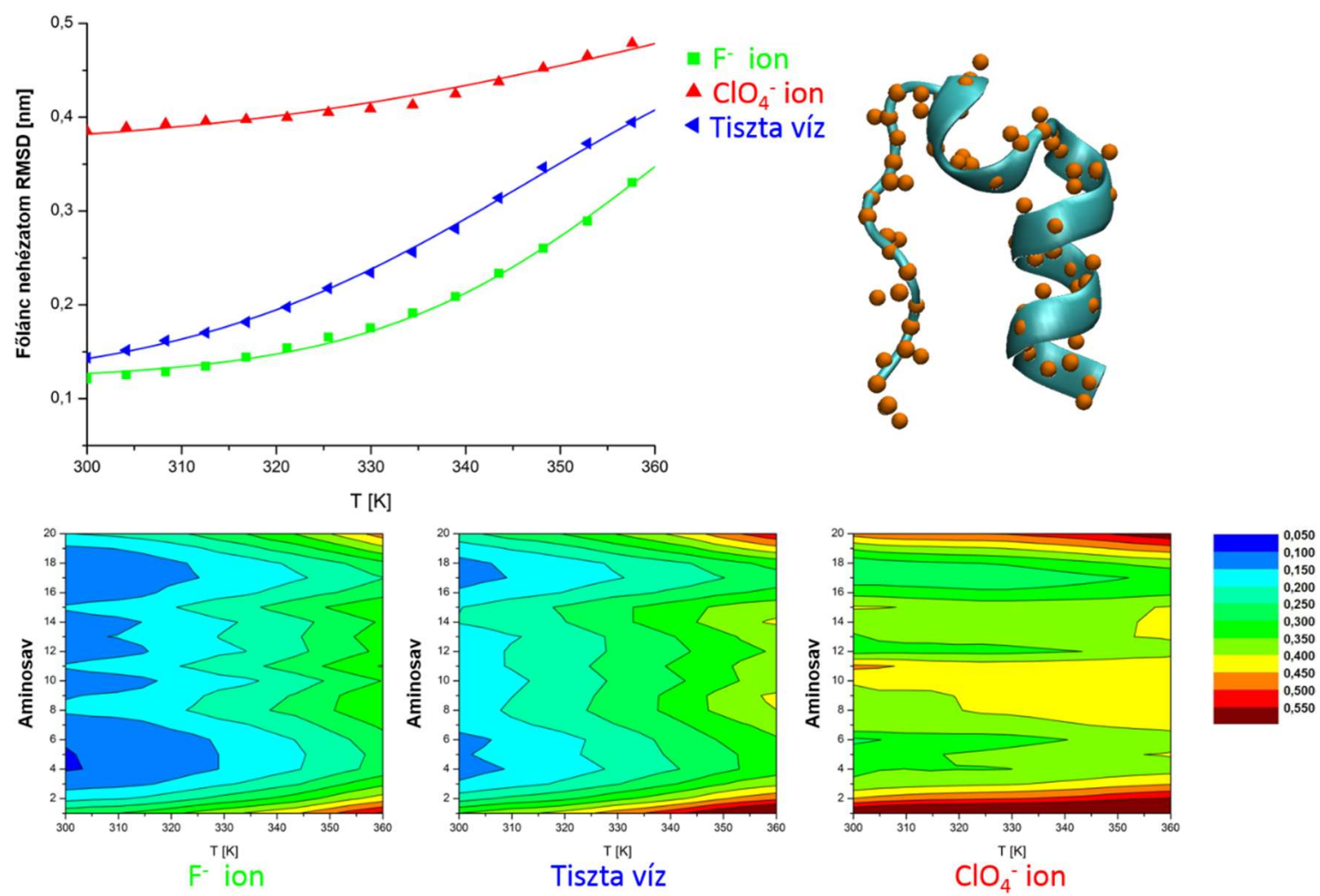

32. ábra A tc5b minifehérje föláncának nehézatom RMSD átlagának hőmérséklet függése (felül) és a vizsgált hőmérsékleti sávban az aminosavankénti eloszlása (alul).

A másik mennyiség, amit a térszerkezet stabilitásának mérésére használhatunk az a minifehérje főlánc-nehézatomjainak az RMSD-je, a kiindulási szerkezetet használva referenciának. E mennyiség átlagos értékének meghatároztuk a hőmérsékletfüggését, ugyanakkor származtattuk az aminosavankénti értékeket is (32. ábra), mint a helicitás esetében. Az RMSD átlagok tekintetében is a HS-nak megfelelő rendezettséget látunk. A kaotróp só már $300 \mathrm{~K}$-en jelentős destabilizációs hatást fejt ki, ami a teljes hőmérsékleti tartományban jellemző. Ugyanakkor a F${ }^{-}$ ionok jelenléte 300-360 K között minden esetben alacsonyabb értékeket eredményez. A Lys ${ }^{8}$ aminosav és az N-terminális szomszédságában váltják ki a legjelentősebb RMSD különbségeket a perklorát ionok, melyek kitüntetett CP kölcsönhatási helyek. Így a közvetlen fehérje-ion kölcsönhatás együtt jár a szerkezeti stabilitás csökkenésével, ahogy a fent bemutatott kaotróp destabilizációs mechanizmus szerint várható. A F-ionok pedig szinte a teljes szekvencia tekintetében csökkentik az RMSD értékeket a tiszta vizes esethez hasonlítva.

Végül pedig olyan átlagos minimális távolságokat számoltunk ki egyes aminosav párok oldallánc-nehézatomjai között, melyek a szerkezeti stabilitás szempontjából kitüntetett fontosságú kölcsönhatásokban vesznek részt (33. ábra). Mind a sóhíd (Asp ${ }^{9}-\operatorname{Arg}^{16}$ ), mind a hidrofób kölcsönhatások $\left(\operatorname{Pro}^{19}-\mathrm{Tyr}^{3}\right.$; Pro $^{12}-\operatorname{Trp}^{6}$ ) esetében HS-nak megfelelő rendezettség tapasztalható, azaz a perklorát ion megnöveli, míg a fluorid ion lecsökkenti az átlagos minimális távolságot a tiszta vizes esethez képest. Ami rendre a térszerkezet „meglazulását” és stabilizálódását jelzi. 

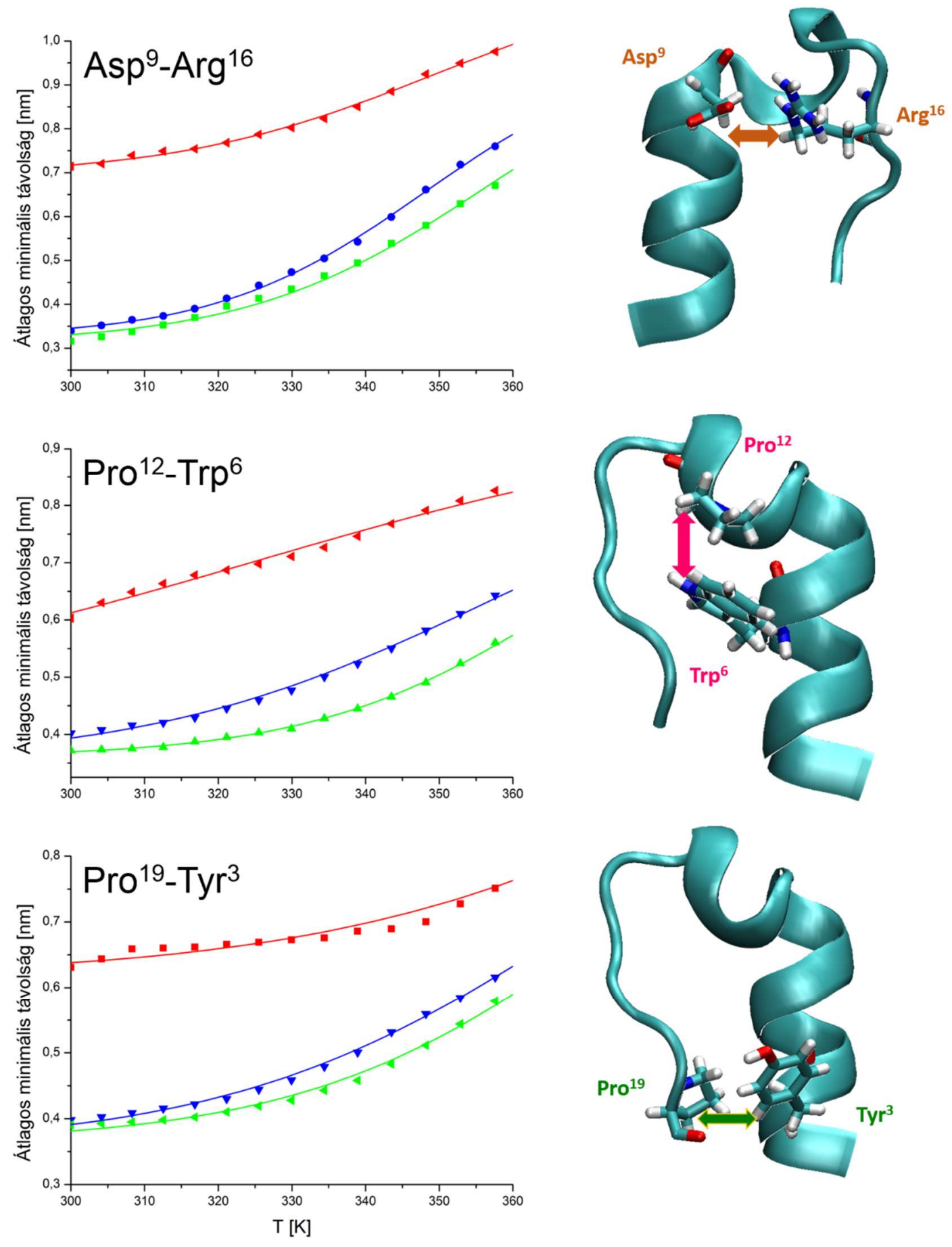

33. ábra A sóhíd alkotói minimális távolságának-, továbbá a $\operatorname{Pro}^{12}-\operatorname{Trp}^{6}$ és $\operatorname{Pro}^{19}-\operatorname{Tyr}^{3}$ aminosavak közötti minimális távolságnak a hőmérséklet függése; rendre fentről lefelé.

A szabadenergia-profil (14. ábra) származtatásához szükséges volt az átmeneti hőmérséklet számolása. Az átmeneti hőmérséklet származtatását sokféle mennyiség felhasználásával el lehet végezni. A tc $5 \mathrm{~b}$ minifehérje esetén meghatároztuk az átmeneti hömérsékletet a SASA (11. ábra), a teljes helicitás (31. ábra), a fölánc nehézatom RMSD (32. ábra), és egyéb adatsorok felhasználásával, az illesztési eljárás minden mennyiség esetén azonos volt. A helicitás adatok 
(amelyre kísérleti eredmények is rendelkezésre állnak) felhasználásával a tiszta vizes esetben a számolt érték 340,47 K-nek adódott. Mindazonáltal, a többi vizsgált mennyiség esetén is az illesztett értékek meglehetösen közel estek egymáshoz (maximálisan 2-3 K eltérést mutatva a helicitáshoz tartozó értéktő), így egyazon konformációs sokaságot jelölve ki a REMD trajektóriák közül. A tiszta vizes rendszer átmeneti állapotához tartozó szabadenergia profil így nem kizárólagosan egy, a rendszer állapotát jellemző mennyiségre való tekintettel lett meghatározva, hanem ilyen mennyiségek egy halmazára vonatkozóan. 


\section{7. Összefoglalás}

A Hofmeister-effektus egy több mint 100 éve ismert jelenség, melyet elsőként a globuláris fehérjék oldhatóságát vizsgálva figyeltek meg: egyes sók növelték az oldhatóságot, mások csökkentették azt. Az ionok közvetlen közelükben jelentősen megváltoztatják a vízszerkezetet, továbbá kölcsönhatásba lépnek egymással és egyéb hidratált molekulákkal is. A Hofmeisteraktív ionok befolyásolják a fehérjék térszerkezetét és annak stabilitását, ugyanakkor az ionok hatása nem korlátozódik csak fehérjékre. A széleskörű előfordulás és az intenzív elméleti- és kísérleti kutatási munka ellenére egységes, a Hofmeister effektus átfogóan leíró elmélet a mai napig nem áll rendelkezésre.

A tc5b minifehérjét választva modellrendszernek, a Hofmeister effektusra vonatkozó vizsgálatokat végeztünk klasszikus molekuladinamikai módszereket használva. A szimulációk során alkalmaztunk egy- és többatomos Hofmeister-aktív ionokat is, származtattunk 32 különböző hőmérséklethez tartozó konformációs sokaságot REMD számolásokkal, emellett a minifehérje és a hidratációs környezete közötti határfelület tulajdonságait 100 ns hosszúságú NPT számolások felhasználásával határoztuk meg. A minifehérje térszerkezetére vonatkozó adatokból származtattunk több, a szerkezeti stabilitás- és az intramolekuláris kölcsönhatások ionok hatására bekövetkező változását leíró mennyiséget.

A klasszikus MD szimulációk alkalmazásából eredő közelítések ellenére, a számolásaink demonstrálták, hogy a tc5b minifehérje a TIP3P explicit vízmodellel és a nem polarizálható ff99SB-ILDN erőtér használatával alkalmas modellrendszer a Hofmeister effektus alapvető tulajdonságainak tanulmányozására. A tisztán kvantummechanikai megközelítés - bár pontosabb leírást biztosíthatna például a Hofmeister effektust kiváltó ionok egymás közötti-, illetve az oldószerrel és egyéb molekulákkal létrejövő kölcsönhatásaira vonatkozóan - azonban ekkora méretü rendszereknél gyakorlatilag nem alkalmazható, mert az ehhez szükséges mértékü mintavételezés jelenleg nem lehetséges.

Az oldószer számára hozzáférhető felület nagyságára vonatkozó értékek átlagából és azok fluktuációjából a Lineáris válasz elmélet felhasználásával meghatároztuk a minifehérje-víz határfelületen fellépő, a Hofmeister-aktív ionok által kiváltott felületi feszültség változásokat. Eredményeink szerint, a tiszta vizes esethez viszonyítva növekedett a felületi feszültség értéke kozmotróp anionok jelenlétében, és csökkent, ha kaotróp anionokat adtunk hozzá a rendszerhez. Mindezek megfelelnek a Dér és mtsi. által javasolt [20,21] határfelületi feszültség koncepció előrejelzéseinek. Ugyanakkor, a határfelületi feszültség koncepcióban használt feltevések validitásának ellenőrzésére meghatároztuk a szabadenergia függését a minifehérje állapotára jellemző oldószer számára hozzáférhető felület értékétől. A tiszta vizes rendszer átmeneti hőmérsékletéhez tartozó szerkezeti sokaságát használva U-alakú szabadenergia profilt származtattunk. A számolást elvégeztük a leginkább kaotróp és kozmotróp ion jelenlétében. Az eredmények alátámasztották a határfelületi feszültség koncepcióban használt feltételezéseket.

A felületi feszültség változás mikroszkopikus értelmezését keresve karakterisztikus eltéréseket azonosítottunk az anionok határfelületi eloszlását illetően. Ezek az eltérések erős függést mutattak az egyes anionok Hofmeister sorban elfoglalt helyzetüktől. Az ioneloszlást érintő 
vizsgálatokat radiális eloszlásfüggvények segítségével végeztük el. Kimutattuk, hogy a kaotróp hatású ionok felhalmozódnak a fehérje-víz határfelületen, viszont ez a tulajdonság a kozmotróp ionokra nem jellemző, legfeljebb csak a jelentős pozitív töltést hordozó felszíni atomok közelében.

Emellett meghatároztuk a határfelületi vízmolekulák orientációs tulajdonságait és a közöttük kialakuló H-híd kötésrendszer stabilitását leíró autokorrelációs függvényeket is. A határfelületi vízmolekulákat donorok és akceptorok halmazára osztottuk. Az akceptor szerepet játszó vízmolekulák autokorrelációs függvényei HS szerinti rendezettséget mutattak, a kozmotróp ion lassította, a kaotróp ionok pedig gyorsították a vízmolekulák reorientációját a tiszta vizes esethez képest. Ez a rendezettség a donor vízmolekulák esetében már nem áll fenn, mindazonáltal a fehérjefelszín közelében minden esetben a reorientáció jelentősen lassabb volt a tömbfázis esetében származtatott eredményekhez hasonlítva.

Mind az ionok anizotróp határfelületi eloszlásának, mind a vízmolekulák orientációs tulajdonságai változásainak kitüntetett hatása van a tc5b minifehérje kompaktságára (amit a SASA mennyiséggel jellemeztünk).

A vizsgálataink másik csoportja az oldott ionok által kiváltott, a fehérje-víz határfelületen fellépő változások részletes feltérképezésére irányult.

A tc5b minifehérje oldódási folyamatát két egymást követő szakaszra osztottuk. Az első (felhalmozódási) állapotban a minifehérje szerkezetét fixen tartottuk és megvizsgáltuk a lokális hidratációs tulajdonságok fluorid és perklorát ionok által kiváltott változásait, megkülönböztetett figyelmet szentelve a töltött és poláros kölcsönhatási helyekre. Kimutattuk, hogy a minifehérje és a hidratációs környezete közötti kölcsönhatási energia csökken a kozmotróp ionok jelenlétében, a kaotróp ionok esetében pedig nő a tiszta vizes esethez hasonlítva. Ennek a változásnak a részleteit is megvizsgáltuk, külön-külön kiszámítva az ionok és a vízmolekulák járulékát. A fehérje-víz kölcsönhatási energia mindkét Hofmeister-aktív ion jelenlétében csökkent, míg a fehérje-ion kölcsönhatás sokkal erősebb a perklorát ion jelenlétében, mint a fluorid ion esetében.

További eredményeink szerint a Hofmeister-aktív ionok és a tc $5 \mathrm{~b}$ protonált csoportjai közötti párformálódás jellemzői megfelelnek a Collins-szabálynak. Ez a megfigyelés kiterjeszthető az alacsonyabb parciális töltéssel rendelkező kötési helyekre, melyek a fehérjefelszín sekély mélyedéseiben találhatóak. Vagyis a kaotróp anionok minden vizsgált kölcsönhatási helyen a közvetlen kölcsönhatást részesítették előnyben, a kozmotróp anionokra pedig a vízmolekulák által közvetített kölcsönhatás volt a jellemző.

A tc5b első hidratációs burkában található vízmolekulákat három csoportba soroltuk a minifehérje és a vízmolekulák közötti kötési energia alapján. Azt is kimutattuk, hogy a legerősebben kötött határfelületi vízmolekulák reorientációs dinamikáját rendre gyorsítja, illetve lassítja a perklorát és fluorid ionok jelenléte összevetve a tiszta vizes rendszer 
eredményeivel. Másfelöl pedig, a gyengébben-, vagy közepesen kötött vízmolekulák esetében mindkét Hofmeister-aktív ion lassulást eredményezett.

A hidratációs folyamat második (átrendeződési) állapotában a minifehérje és az ionok hidratációs tulajdonságait vizsgáltuk, az előbbire vonatkozó kényszerek elhagyása mellett. Azt tapasztaltuk, hogy a kaotróp ionok jelentősen több vízmolekulát vesztenek a hidratációs burkukból, mint a kozmotrópok, az utóbbiak esetében alig tapasztalható változás.

Összességében a számolásaink megvilágították a tc5b minifehérje kaotróp destabilizációs és kozmotróp stabilizációs folyamatainak atomi szintü részleteit. Az elöbbi esetben a közvetlen fehérje-ion kölcsönhatás preferáltsága miatt bekövetkező ion-dehidratáció és a fehérjefelszínen erősen kötött vízmolekulák destabilizálása jellemző. Mindezek teret nyitnak a konformációs fluktuációk erősödésének és a SASA megnövekedésének. A megnövekedett felület viszont több perklorát ion számára teszi lehetővé a hidratációs burka elhagyását és a közvetlen kölcsönhatást a minifehérjével. Ezt tekintjük a kaotróp destabilizáció fő hajtóerejének.

A kozmotróp stabilizáció esetében pedig a minifehérje és az ion hidratációs burkainak átfedése a fontos tényező, mely lassabb vízmolekula-reorientációt okoz a fehérje-víz határfelületen. Ebben az esetben a vízkiszorítás a minifehérje első hidratációs burkából gyakorlatilag elhanyagolható. Alapvetően a vízmolekulák reorientációja miatt csökken a vízmolekulák és a minifehérje közötti kölcsönhatási energia, és ez a minifehérje teljes hidratációs környezetét tekintve így marad, mivel ebben az esetben az ionok járuléka közel sem kompenzál annyit, mint a kaotróp ionok esetében, ezzel stabilizálva a tc $5 b$ térszerkezetét.

A 300-360 K közötti hömérsékleti intervallumban ellentétes felhalmozódási és fluktuációs tulajdonságokat mutattunk ki a vizsgált ionok között. Emellett a szerkezeti stabilitás jellemzésére az oldallánc-nehézatom RMSF-et használtuk fel. A perklorát ionok a kitüntetett felhalmozódási helyek közelében jelentősen megemelik az RMSF értékét, a fluorid ionok viszont a teljes szekvenciára kiterjedően stabilizáló hatást fejtenek ki.

A tc5b minifehérje állapotát egyetlen változóval (oldószer számára hozzáférhető felület) írtuk le. A szerkezeti változások részletesebb jellemzése céljából megvizsgáltuk még a helicitás-, illetve a főlánc-nehézatom RMSD átlagának hőmérsékletfüggését, továbbá ezek aminosavankénti eloszlását. Az átlagos értékeket tekintve a 300-360 K közötti hőmérsékleti intervallumban a Hofmeister sornak megfelelő rendezettséget tapasztaltunk. $\mathrm{Az}$ aminosavankénti értékeket vizsgálva pedig megállapítottuk, hogy a kaotróp anionok jelenlétében az N-terminálisnál található szegmens helicitása azoknál az aminosavaknál csökken leginkább, ahol számottevő a perklorát ionok felhalmozódása és a CP-típusú kölcsönhatás a jellemző. A fluorid ionok a teljes helikális szegmenst stabilizálják. Hasonlóan, a legnagyobb szerkezeti változás (RMSD) is ezeknél az aminosavaknál tapasztalható perklorát ionok hozzáadásakor, továbbá a teljes szerkezetre vett átlagértékekben pedig szintén Hofmeister sor szerinti rendezettség áll fenn. Mindezekkel összhangban lévő módosulásokat tapasztaltunk a sóhíd és a szerkezeti stabilitás szempontjából fontos hidrofób kölcsönhatások tekintetében. Ezek a szerkezeti információk is alátámasztják a határfelületi feszültség koncepcióval kapcsolatos eredményeinket és a Hofmeister effektus mikroszkopikus szintü magyarázatát. 
Az eredményeink kapcsolatot teremtenek a Hofmeister effektus fenomenologikus- és mikroszkopikus értelmezése között a határfelületi tulajdonságok szerepét vizsgálva és egyúttal igazolják a határfelületi feszültség koncepció alkalmazhatóságát is egy klasszikus modell keretein belül is. 


\section{Summary}

The notion of Hofmeister effect has been known for more than 100 years. It was first described as a phenomenon concerning the solubility of globular proteins: some salts were found to increase solubility, whereas others decreased it. The ions in watery environments change the local water structure and interact with other ions and with other hydrated molecules. The Hofmeister-active ions influence the spatial structure of proteins and also the stability of the realized conformation. Moreover, the effects of co-soluted ions aren't limited to proteins only. Despite their widespread occurrence and the intense theoretical- and experimental research efforts, a comprehensive interpretation of the Hofmeister effect isn't available till the present day.

Utilizing the tools of classical molecular dynamics, Hofmeister effect related investigations were carried out choosing the tc $5 \mathrm{~b}$ miniprotein as a model system. On the course of computational simulations, one- and polyatomic Hofmeister-active anions' sodium salts were applied. In order to investigate the conformational ensembles of the miniprotein, REMD trajectories were derived at 32 temperatures, while for the examination of the protein-water interface and the properties of the local hydration environment, $100 \mathrm{~ns}$ long NPT simulations were utilized. Ion-induced changes with respect to conformational stability and intramolecular interactions were obtained by taking into account several quantities describing the spatial structure of the miniprotein.

Despite the inherent approximations of MD methods applying classical force fields, these calculations demonstrated that the simultaneous usage of the TIP3P water model and the nonpolarizable ff99SB-ILDN force filed provide an appropriate model for the investigation of basic Hofmeister effect related features. An approach utilizing purely quantum mechanics could, although, offer a more accurate description of interactions formed between ions, water molecules and other molecules. However, for systems of comparable size to the investigated model system, these methods cannot be applied due to the current impossibility of sufficient sampling.

The surface tension changes of the miniprotein-water interface induced by Hofmeister-active ions were calculated from the average value of the solvent accessible surface area and its fluctuation, utilizing the Linear Response Theorem. According to these results, kosmotropic anions increased the value of surface tension, whereas chaotropic ones decreased it, compared to the neat water case. These findings are in line with the predictions of Dér and coworkers [20, 21] provided in the Interfacial Tension Concept. Furthermore, in order to check the validity of assumptions used in the Interfacial Tension Concept, the solvent accessible surface area - a descriptor of the miniproteins state - was calculated as a function of the systems' free energy. Using the conformational ensemble of the neat water system belonging to the transition temperature, a U-shaped free energy profile could be derived. This calculation was performed for model systems containing the most chaotropic and kosmotropic ions and the corresponding results confirmed the assumption of the Interfacial Tension Concept. 
Attempting to find a microscopic interpretation for the interfacial tension changes, characteristic differences were identified with respect to the anion distribution at the miniprotein-water interface. These differences were determined using radial distribution functions, and show a strong correlation to the investigated ions' position in the Hofmeister series. It could be deduced that chaotropic anions accumulate at the protein-water interface, while kosmotropic anions miss this feature; gathering of kosmotropic anions was observed only at surface atoms carrying significant positive charge.

Besides, autocorrelation functions of water molecules present at the interfacial region were calculated in order to describe the stability of the H-bond system formed between them. These interfacial water molecules were classified as donors or acceptors. The autocorrelation functions of water molecules acting as acceptors show an ordering which is in compliance with their respective position in the Hofmeister series; kosmotropic ions hindered, whereas chaotropic ions accelerated the reorientation of water molecules compared to the neat water case. There is no such ordering with respect to the donor water molecules, however, in the interfacial region the reorientation proved to be a much slower process compared to the bulk results.

Both the anisotropic accumulation of ions at the protein-water interface and the changes of reorientation dynamics of interfacial water molecules have a profound effect on the compactness of the miniprotein (which was described by the solvent accessible surface area).

In order to reveal the in-detail changes of the protein-water interface induced by co-soluted Hofmeister-active ions, another set of investigations was carried out.

The dissolution process of the Trp-cage miniprotein was separated into two subsequent parts. In the first ("promotion") part, the protein structure was fixed, and changes of local hydration properties induced by the presence of the selected fluoride or perchlorate ions were investigated, with a special focus on the interaction of Hofmeister-active anions with the charged and polar sites. It was pointed out that the interaction energy of the miniprotein with its environment increases in the presence of chaotropic anions compared to the neat water case, and decreases if kosmotropic anions are added. We also uncovered the details of this change, calculating the contribution of water molecules and ions separately. It was found that the protein-water interaction energy decreases in the presence of both Hofmeister-active ions, while the proteinion interaction is notably stronger in the presence of perchlorate ions compared to the case of fluoride ions.

Furthermore, it was established that pair formations between the investigated Hofmeister-active anions and the protonated groups of the Trp-cage miniprotein follow the Collins's rule. This behavior could be extended to the atoms with positive partial charge situated in a concavity on the surface of the miniprotein. Overall, the chaotropic anions favor direct protein-ion interaction at all the investigated sites, while kosmotropic ones prefer the solvent-mediated interaction types. 
The water molecules in the first hydration shell of tc $5 \mathrm{~b}$ were divided into three groups, with respect to their interaction energy with the miniprotein. It was also pointed out that the most strongly bound water molecules have faster or slower rotational dynamics in the presence of $\mathrm{ClO}_{4}^{-}$or $\mathrm{F}^{-}$ions, respectively, than water molecules with similar binding energy in the neat water case. On the other hand, the rotational dynamics of the rest of the water molecules in the first hydration shell of the fixed protein surface was slowed down by both types of ions, as compared to that in neat water.

In the second ("rearrangement") phase of the solution process, we followed changes of the hydration of ions and the protein, induced by the conformational relaxation of the latter. It turned out that chaotropic anions lose more hydration water, while kosmotropic ones hardly change their hydration.

Overall, our calculations shed more light on the atomic mechanisms of chaotropic destabilization and kosmotropic stabilization processes in the Trp-cage miniprotein. In the former case, the dehydration of ions due to the preferred direct protein-ion interaction, and the destabilization of strongly bound interfacial water molecules are the most significant features. These changes increase the conformational fluctuations and the overall value of solvent accessible surface area. The increased interfacial area facilitates the dehydration of further perchlorate ions, and therefore the formation of more direct protein-ion interactions. That could be regarded as the main driving force of chaotropic destabilization.

In the case of kosmotropic stabilization, overlapping of the solvation shells of the miniprotein and the ions is the most relevant factor, which leads to a slower rotational dynamics of the interfacial water molecules. The dehydration in the first solvation shells is found to be a negligible feature in this process. The decrease in the protein-water interaction energy is basically due to the reorientation of water molecules, and, with respect to the overall proteinhydration environment interaction energy, this decrease also persists, because in this case the ions' contribution does not compensate as much as in the case of chaotropic ions. These factors altogether invoke a damping of the conformational dynamics of the protein-water interface, and the stabilization of the spatial structure of tc $5 \mathrm{~b}$ miniprotein.

Different accumulation and fluctuation properties were identified for the investigated Hofmeister-active ions in the 300-360 K temperature interval. Besides, in order to the describe the structural stability of tc $5 \mathrm{~b}$, the sidechain heavy atom RMSF (root mean square fluctuation) was used. The presence of perchlorate ions at preferred accumulation sites increases the RMSF, whereas the fluoride ions exert a stabilization effect alongside the whole sequence.

Only one descriptor the solvent accessible surface area was used to characterize the state of the tc $5 \mathrm{~b}$ miniprotein. In order to obtain a more detailed mapping of the structural features, the temperature dependence of average fractional helicity and the main-chain heavy atom RMSD (root mean square deviation) were calculated, as well as their corresponding values with respect to amino acids. The ordering of the average fractional helicity and the RMSD is in accordance with the Hofmeister series in the considered 300-360 K temperature interval. Taking into account the per amino acid values, it could be deduced that in the presence of chaotropic anions the helical content decreases sharply at amino acids where perchlorate ions tend to accumulate, 
and consequently, at the preferred contact pair type ion-protein interaction sites. In contrast, fluoride ions seem to have a helix-stabilizing effect, extending to the whole helical segment. Similarly, upon perchlorate ion addition, the most significant structural instability (measured by RMSD) could be detected at the same amino acids where the helical content was decreased, and also for the whole-sequence averages a Hofmeister-series consistent ordering could be observed. Alterations concerning the stability of the salt bridge and hydrophobic interactions (which are important factors in terms of structural stability) were in line with the above presented findings. Overall, the results originated from the Interfacial Tension Concept and the proposed microscopic interpretation of the Hofmeister effect were evidenced by the obtained structural information.

The above presented results make a connection between the phenomenological and microscopic interpretation of the Hofmeister effect by revealing the role of interfacial features in this phenomenon, and at the same time verify the applicability of the Interfacial Tension Concept within the limits of a classical model. 


\section{Köszönetnyilvánítás}

Először is a családomnak szeretném kifejezni tiszta szívvel köszönetemet, a véget nem érő gondoskodásért és szeretetért. Édesanyám és édesapám mindennapokban nyújtott fáradhatatlan segítsége és szakadatlan áldozatkészsége végig elkísért tanulmányaim és munkám során. Köszönet és hála illeti meg Tóth Lászlót is, aki rengeteget segített az értekezés korrektúrázásában, aprólékos átnézésében.

Köszönöm Bogár Ferenc témavezetőmnek az értekezés elkészítése során adott hasznos ötleteit, iránymutatásait, odafigyelését, jó szándékú kritikáit, kitartó türelmét és tanácsait. Hálával tartozom Dér Andrásnak társ-témavezetőmnek is, aki a dolgozat megírásához szintén nélkülözhetetlen munkával járult hozzá.

Hálásan köszönöm valamennyi munkatársam segítő támogatását is.

A fentiekben bemutatott eredmények a Nemzeti Kutatási, Fejlesztési és Innovációs Hivatal támogatásával (OTKA K 101821, OTKA K 101825, és GINOP-2.3.2-15-2016-00001) végzett kutatásokból származnak. Köszönöm továbbá a NIIF-nek a szükséges számítástechnikai kapacitás rendelkezésünkre bocsájtását a szegedi és debreceni központokban. 


\section{Irodalomjegyzék}

1. Zhang, Y. and P.S. Cremer, Interactions between macromolecules and ions: The Hofmeister series. Curr Opin Chem Biol, 2006. 10(6): p. 658-63.

2. Cacace, M.G., E.M. Landau, and J.J. Ramsden, The Hofmeister series: salt and solvent effects on interfacial phenomena. Quarterly Reviews of Biophysics, 1997. 30(3): p. 241-277.

3. Collins, K.D. and M.W. Washabaugh, The Hofmeister effect and the behaviour of water at interfaces. Q Rev Biophys, 1985. 18(4): p. 323-422.

4. Tadeo, X., et al., Protein Stabilization and the Hofmeister Effect: The Role of Hydrophobic Solvation. Biophysical Journal, 2009. 97(9): p. 2595-2603.

5. Baldwin, R.L., How Hofmeister ion interactions affect protein stability. Biophysical Journal, 1996. 71(4): p. 2056-2063.

6. Hofmeister, F., Zur Lehre von der Wirkung der Salze. Arch. Exp. athol. Pharmakol., 1888. 24: p. 247-260.

7. Zavodszky, P., et al., Adjustment of conformational flexibility is a key event in the thermal adaptation of proteins. Proceedings of the National Academy of Sciences of the United States of America, 1998. 95(13): p. 7406-7411.

8. Ball, P., Water as an active constituent in cell biology. Chemical Reviews, 2008. 108(1): p. 74-108.

9. Ebel, C., et al., Relative role of anions and cations in the stabilization of halophilic malate dehydrogenase. Biochemistry, 1999. 38(28): p. 9039-9047.

10. Dunker, A.K., et al., Intrinsically disordered protein. Journal of Molecular Graphics \& Modelling, 2001. 19(1): p. 26-59. 
11. Frauenfelder, H., S.G. Sligar, and P.G. Wolynes, The Energy Landscapes and Motions of Proteins. Science, 1991. 254(5038): p. 1598-1603.

12. Austin, R.H., et al., Dynamics of Ligand-Binding to Myoglobin. Biochemistry, 1975. 14(24): p. 5355-5373.

13. Qin Y., W.L., Zhong D., Dynamics and mechanism of ultrafast water-protein interactions. Proc. Natl. Acad. Sci., 2016. 113(30): p. 8424-8429.

14. Frank HS, E.M., Free volume and entropy in condensed systems iii. Entropy in binary liquid mixtures; partial molal entropy in dilute solutions; structure and thermodynamics in aqueous electrolytes. The Journal of Chemical Physics, 1945. 13(11): p. 507-532.

15. Smolin, N. and R. Winter, Molecular dynamics simulations of staphylococcal nuclease: Properties of water at the protein surface. Journal of Physical Chemistry B, 2004. 108(40): p. 15928-15937.

16. Haider, K., et al., Enthalpic Breakdown of Water Structure on Protein Active-Site Surfaces. Journal of Physical Chemistry B, 2016. 120(34): p. 8743-8756.

17. Lo Nostro, P. and B.W. Ninham, Hofmeister phenomena: an update on ion specificity in biology. Chem Rev, 2012. 112(4): p. 2286-322.

18. Lo Nostro, P. and B.W. Ninham, Editorial: Electrolytes and specific ion effects. New and old horizons. Current Opinion in Colloid \& Interface Science, 2016. 23: p. A1A5.

19. Der, A. and J.J. Ramsden, Evidence for loosening of a protein mechanism. Naturwissenschaften, 1998. 85(7): p. 353-355.

20. Der, A., et al., Interfacial water structure controls protein conformation. J Phys Chem B, 2007. 111(19): p. 5344-50. 
21. Neagu, A., M. Neagu, and A. Der, Fluctuations and the Hofmeister effect. Biophysical Journal, 2001. 81(3): p. 1285-1294.

22. Collins, K.D., G.W. Neilson, and J.E. Enderby, Ions in water: Characterizing the forces that control chemical processes and biological structure. Biophysical Chemistry, 2007. 128(2-3): p. 95-104.

23. Sun, L., et al., Molecular Dynamics Simulations of the Surface Tension and Structure of Salt Solutions and Clusters. Journal of Physical Chemistry B, 2012. 116(10): p. 3198-3204.

24. Kalcher, I., et al., Ion specific correlations in bulk and at biointerfaces. Journal of Physics-Condensed Matter, 2009. 21(42).

25. Dzubiella, J., Salt-specific stability and denaturation of a short salt-bridge-forming alpha-helix. Journal of the American Chemical Society, 2008. 130(42): p. 1400014007.

26. Dzubiella, J., Salt-Specific Stability of Short and Charged Alanine-Based alphaHelices. Journal of Physical Chemistry B, 2009. 113(52): p. 16689-16694.

27. Asciutto, E.K., et al., Sodium Perchlorate Effects on the Helical Stability of a Mainly Alanine Peptide. Biophysical Journal, 2010. 98(2): p. 186-196.

28. Neidigh, J.W., R.M. Fesinmeyer, and N.H. Andersen, Designing a 20-residue protein. Nature Structural Biology, 2002. 9(6): p. 425-430.

29. Hudaky, P., et al., Cooperation between a salt bridge and the hydrophobic core triggers fold stabilization in a Trp-cage miniprotein. Biochemistry, 2008. 47(3): p. 1007-1016.

30. Paschek, D., H. Nymeyer, and A.E. Garcia, Replica exchange simulation of reversible folding/unfolding of the Trp-cage miniprotein in explicit solvent: On the structure and possible role of internal water. Journal of Structural Biology, 2007. 157(3): p. 524533. 
31. Paschek, D., S. Hempel, and A.E. Garcia, Computing the stability diagram Trp-cage miniprotein of the. Proceedings of the National Academy of Sciences of the United States of America, 2008. 105(46): p. 17754-17759.

32. Day, R., D. Paschek, and A.E. Garcia, Microsecond simulations of the folding/unfolding thermodynamics of the Trp-cage miniprotein. Proteins-Structure Function and Bioinformatics, 2010. 78(8): p. 1889-1899.

33. Paschek, D., R. Day, and A.E. Garcia, Influence of water-protein hydrogen bonding on the stability of Trp-cage miniprotein. A comparison between the TIP3P and TIP4PEw water models. Physical Chemistry Chemical Physics, 2011. 13(44): p. 1984019847.

34. Juraszek, J. and P.G. Bolhuis, Sampling the multiple folding mechanisms of Trp-cage in explicit solvent. Proceedings of the National Academy of Sciences of the United States of America, 2006. 103(43): p. 15859-15864.

35. Streicher, W.W. and G.I. Makhatadze, Unfolding thermodynamics of Trp-cage, a 20 residue miniprotein, studied by differential scanning calorimetry and circular dichroism spectroscopy. Biochemistry, 2007. 46(10): p. 2876-2880.

36. Halabis, A., et al., Conformational Dynamics of the Trp-Cage Miniprotein at Its Folding Temperature. Journal of Physical Chemistry B, 2012. 116(23): p. 6898-6907.

37. J., S., Über Die Konstitution Der Salzlösungen Auf Grund Ihres Verhaltens Zu Kohlensäure. Z. Phys. Chem., 1889. 4(8).

38. Melander, W. and C. Horvath, Salt Effects on Hydrophobic Interactions in Precipitation and Chromatography of Proteins - Interpretation of Lyotropic Series. Archives of Biochemistry and Biophysics, 1977. 183(1): p. 200-215.

39. Arakawa, T. and S.N. Timasheff, Preferential Interactions of Proteins with Salts in Concentrated-Solutions. Biochemistry, 1982. 21(25): p. 6545-6552. 
40. Lin, T.Y. and S.N. Timasheff, On the role of surface tension in the stabilization of globular proteins. Protein Science, 1996. 5(2): p. 372-381.

41. Schellman, J.A., Protein stability in mixed solvents: A balance of contact interaction and excluded volume. Biophysical Journal, 2003. 85(1): p. 108-125.

42. A., H., Concerning the Physical Characteristics of Solutions in Correlation Ii. Surface Tension and

Electronic Conductivity of Watery Salt Solutions. Ann Phys, 1910. 33(41).

43. Pegram, L.M. and M.T. Record, Thermodynamic origin of Hofmeister ion effects. Journal of Physical Chemistry B, 2008. 112(31): p. 9428-9436.

44. Lee, B. and F.M. Richards, The interpretation of protein structures: estimation of static accessibility. J Mol Biol, 1971. 55(3): p. 379-400.

45. Shrake, A. and J.A. Rupley, Environment and exposure to solvent of protein atoms. Lysozyme and insulin. J Mol Biol, 1973. 79(2): p. 351-71.

46. PW., A., Physical Chemistry. 1990, Oxford: Oxford University Press.

47. RW., G., Ionic Processes in Solution. 1953, New York: McGraw-Hill.

48. Tanford, C., Interfacial Free-Energy and the Hydrophobic Effect. Proceedings of the National Academy of Sciences of the United States of America, 1979. 76(9): p. 41754176.

49. Sinanoglu, O., Microscopic Surface-Tension down to Molecular Dimensions and Microthermodynamic Surface-Areas of Molecules or Clusters. Journal of Chemical Physics, 1981. 75(1): p. 463-468.

50. Terpstra, P., D. Combes, and A. Zwick, Effect of Salts on Dynamics of Water - a Raman-Spectroscopy Study. Journal of Chemical Physics, 1990. 92(1): p. 65-70. 
51. Leberman, R. and A.K. Soper, Effect of High-Salt Concentrations on Water-Structure. Nature, 1995. 378(6555): p. 364-366.

52. Neagu, A., M. Neagu, and A. Der, Active transport modulated by barrier fluctuations. Bioelectronic Applications of Photochromic Pigments, 2001. 335: p. 225-243.

53. Khoroshyy, P., A. Der, and L. Zimanyi, Effect of Hofmeister cosolutes on the photocycle of photoactive yellow protein at moderately alkaline $\mathrm{pH}$. Journal of Photochemistry and Photobiology B-Biology, 2013. 120: p. 111-119.

54. G., G., Unpublished.

55. Toth, K., et al., Colourful nucleosomes. European Biophysics Journal with Biophysics Letters, 2015. 44: p. S143-S143.

56. Chen, F. and P.E. Smith, Theory and computer simulation of solute effects on the surface tension of liquids. Journal of Physical Chemistry B, 2008. 112(30): p. 89758984.

57. Ben-Naim, A., Molecular Theory of Solutions. 2006, Oxford, U.K. : Oxford University Press.

58. Pierce, V., et al., Recent applications of Kirkwood-Buff theory to biological systems. Cell Biochemistry and Biophysics, 2008. 50(1): p. 1-22.

59. Horinek, D. and R.R. Netz, Can Simulations Quantitatively Predict Peptide Transfer Free Energies to Urea Solutions? Thermodynamic Concepts and Force Field Limitations. Journal of Physical Chemistry A, 2011. 115(23): p. 6125-6136.

60. Decherchi, S., et al., Implicit solvent methods for free energy estimation. Eur J Med Chem, 2015. 91: p. 27-42.

61. Lazaridis, T., G. Archontis, and M. Karplus, Enthalpic contribution to protein stability: insights from atom-based calculations and statistical mechanics. Adv Protein Chem, 1995. 47: p. 231-306. 
62. Levy, R.M., et al., On the nonpolar hydration free energy of proteins: surface area and continuum solvent models for the solute-solvent interaction energy. J Am Chem Soc, 2003. 125(31): p. 9523-30.

63. Gallicchio, E., K. Paris, and R.M. Levy, The AGBNP2 Implicit Solvation Model. J Chem Theory Comput, 2009. 5(9): p. 2544-2564.

64. Ooi, T., et al., Accessible surface areas as a measure of the thermodynamic parameters of hydration of peptides. Proc Natl Acad Sci U S A, 1987. 84(10): p. 3086-90.

65. Knight, J.L. and C.L. Brooks, 3rd, Surveying implicit solvent models for estimating small molecule absolute hydration free energies. J Comput Chem, 2011. 32(13): p. 2909-23.

66. Brieg, M., et al., Generalized Born implicit solvent models for small molecule hydration free energies. Phys Chem Chem Phys, 2017. 19(2): p. 1677-1685.

67. Zhang, J., et al., Comparison of Implicit and Explicit Solvent Models for the Calculation of Solvation Free Energy in Organic Solvents. J Chem Theory Comput, 2017. 13(3): p. 1034-1043.

68. Gibb, C.L.D. and B.C. Gibb, Anion Binding to Hydrophobic Concavity Is Central to the Salting-in Effects of Hofmeister Chaotropes. Journal of the American Chemical Society, 2011. 133(19): p. 7344-7347.

69. Collins, K.D., Sticky Ions in Biological-Systems. Proceedings of the National Academy of Sciences of the United States of America, 1995. 92(12): p. 5553-5557.

70. Collins, K.D., Why continuum electrostatics theories cannot explain biological structure, polyelectrolytes or ionic strength effects in ion-protein interactions. Biophysical Chemistry, 2012. 167: p. 43-59.

71. Crevenna, A.H., et al., Effects of Hofmeister Ions on the alpha-Helical Structure of Proteins. Biophysical Journal, 2012. 102(4): p. 907-915. 
72. Heyda, J., et al., Urea and Guanidinium Induced Denaturation of a Trp-Cage Miniprotein. Journal of Physical Chemistry B, 2011. 115(28): p. 8910-8924.

73. Rembert, K.B., et al., Molecular Mechanisms of Ion-Specific Effects on Proteins. Journal of the American Chemical Society, 2012. 134(24): p. 10039-10046.

74. Mason, P.E., et al., Specific Interactions of Ammonium Functionalities in Amino Acids with Aqueous Fluoride and Iodide. Journal of Physical Chemistry B, 2010. 114(43): p. 13853-13860.

75. Canchi, D.R., D. Paschek, and A.E. Garcia, Equilibrium Study of Protein Denaturation by Urea. Journal of the American Chemical Society, 2010. 132(7): p. 2338-2344.

76. Iavarone, A.T., et al., Fluorescence probe of Trp-cage protein conformation in solution and in gas phase. Journal of the American Chemical Society, 2007. 129(21): p. 6726-6735.

77. Rovo, P.F., V.; Hegyi, O.; Szolomajer-Csikos, O.; Toth, G. K.; Perczel, A. , Cooperativity network of Trp-cage miniproteins: probing salt-bridges. Journal of Peptide Science, 2011. 17(9): p. 610-619.

78. Iavarone, A.T., D. Duft, and J.H. Parks, Shedding light on biomolecule conformational dynamics using fluorescence measurements of trapped ions. Journal of Physical Chemistry A, 2006. 110(47): p. 12714-12727.

79. Meuzelaar, H., et al., Folding Dynamics of the Trp-Cage Miniprotein: Evidence for a Native-Like Intermediate from Combined Time-Resolved Vibrational Spectroscopy and Molecular Dynamics Simulations. Journal of Physical Chemistry B, 2013. 117(39): p. 11490-11501.

80. Ahmed, Z., et al., UV-resonance raman thermal unfolding study of Trp-cage shows that it is not a simple two-state miniprotein. J Am Chem Soc, 2005. 127(31): p. 10943-50. 
81. Carignano, M.A., G. Karlstrom, and P. Linse, Polarizable ions in polarizable water: A molecular dynamics study. Journal of Physical Chemistry B, 1997. 101(7): p. 11421147.

82. Caleman, C., et al., Atomistic simulation of ion solvation in water explains surface preference of halides. Proceedings of the National Academy of Sciences of the United States of America, 2011. 108(17): p. 6838-6842.

83. Duignan, T.T., D.F. Parsons, and B.W. Ninham, Collins's rule, Hofmeister effects and ionic dispersion interactions. Chemical Physics Letters, 2014. 608: p. 55-59.

84. Duignan, T.T., M.D. Baer, and C.J. Mundy, Ions interacting in solution: Moving from intrinsic to collective properties. Current Opinion in Colloid \& Interface Science, 2016. 23: p. 58-65.

85. Nadig, G., et al., Charge-transfer interactions in macromolecular systems: A new view of the protein/water interface. Journal of the American Chemical Society, 1998. 120(22): p. 5593-5594.

86. Pollard, T.P. and T.L. Beck, Toward a quantitative theory of Hofmeister phenomena: From quantum effects to thermodynamics. Current Opinion in Colloid \& Interface Science, 2016. 23: p. 110-118.

87. Henry, M., Hofmeister series: The quantum mechanical viewpoint. Current Opinion in Colloid \& Interface Science, 2016. 23: p. 119-125.

88. Bogar, F., et al., On the Hofmeister Effect: Fluctuations at the Protein Water Interface and the Surface Tension. Journal of Physical Chemistry B, 2014. 118(29): p. 84968504.

89. Kunz, W., Specific ion effects in colloidal and biological systems. Current Opinion in Colloid \& Interface Science, 2010. 15(1-2): p. 34-39. 
90. Vrbka, L., et al., Specific ion effects at protein surfaces: A molecular dynamics study of bovine pancreatic trypsin inhibitor and horseradish peroxidase in selected salt solutions. Journal of Physical Chemistry B, 2006. 110(13): p. 7036-7043.

91. Vlachy, N., et al., Hofmeister series and specific interactions of charged headgroups with aqueous ions. Advances in Colloid and Interface Science, 2009. 146(1-2): p. 4247.

92. Leontyev, I.V. and A.A. Stuchebrukhov, Polarizable Mean-Field Model of Water for Biological Simulations with AMBER and CHARMM Force Fields. Journal of Chemical Theory and Computation, 2012. 8(9): p. 3207-3216.

93. Savelyev, A. and A.D. MacKerell, Differential Deformability of the DNA Minor Groove and Altered BI/BII Backbone Conformational Equilibrium by the Monovalent Ions $\mathrm{Li}+, \mathrm{Na}+, \mathrm{K}+$, and $\mathrm{Rb}+$ via Water-Mediated Hydrogen Bonding. Journal of Chemical Theory and Computation, 2015. 11(9): p. 4473-4485.

94. Savelyev, A. and A.D. MacKerell, Competition among $\mathrm{Li}+, \mathrm{Na}+, \mathrm{K}+$, and $\mathrm{Rb}+$ Monovalent Ions for DNA in Molecular Dynamics Simulations Using the Additive CHARMM36 and Drude Polarizable Force Fields. Journal of Physical Chemistry B, 2015. 119(12): p. 4428-4440.

95. Savelyev, A. and A.D. MacKerell, Differential Impact of the Monovalent Ions Li+, $\mathrm{Na}+, \mathrm{K}+$, and $\mathrm{Rb}+$ on DNA Conformational Properties. Journal of Physical Chemistry Letters, 2015. 6(1): p. 212-216.

96. Wernersson, E. and P. Jungwirth, Effect of Water Polarizability on the Properties of Solutions of Polyvalent Ions: Simulations of Aqueous Sodium Sulfate with Different Force Fields. Journal of Chemical Theory and Computation, 2010. 6(10): p. 32333240 .

97. Ploetz, E.A., et al., To Polarize or Not to Polarize? Charge-on-Spring versus KBFF Models for Water and Methanol Bulk and Vapor-Liquid Interfacial Mixtures. J Chem Theory Comput, 2016. 12(5): p. 2373-87. 
98. Saha, D. and A. Mukherjee, Impact of Ions on Individual Water Entropy. Journal of Physical Chemistry B, 2016. 120(30): p. 7471-7479.

99. Chevrot, G., E.E. Fileti, and V.V. Chaban, Enhanced Stability of the Model MiniProtein in Amino Acid Ionic Liquids and Their Aqueous Solutions. Journal of Computational Chemistry, 2015. 36(27): p. 2044-2051.

100. Willow, S.Y. and S.S. Xantheas, Molecular-Level Insight of the Effect of Hofmeister Anions on the Interfacial Surface Tension of a Model Protein. Journal of Physical Chemistry Letters, 2017. 8(7): p. 1574-1577.

101. D.A. Case, I.Y.B.-S., S.R. Brozell, D.S. Cerutti, T.E. Cheatham, III, V.W.D. Cruzeiro, T.A. Darden, R.E. Duke, D. Ghoreishi, M.K. Gilson, H. Gohlke, A.W. Goetz, D. Greene, R Harris, N. Homeyer, S. Izadi, A. Kovalenko, T. Kurtzman, T.S. Lee, S. LeGrand, P. Li, C. Lin, J. Liu, T. Luchko, R. Luo, D.J. Mermelstein, K.M. Merz, Y. Miao, G. Monard, C. Nguyen, H. Nguyen, I. Omelyan, A. Onufriev, F. Pan, R. Qi, D.R. Roe, A. Roitberg, C. Sagui, S. Schott-Verdugo, J. Shen, C.L. Simmerling, J. Smith, R. Salomon-Ferrer, J. Swails, R.C. Walker, J. Wang, H. Wei, R.M. Wolf, X. Wu, L. Xiao, D.M. York and P.A. Kollman, AMBER 2018. University of California, San Francisco, 2018.

102. Brooks, B.R., et al., CHARMM: the biomolecular simulation program. J Comput Chem, 2009. 30(10): p. 1545-614.

103. Phillips, J.C., et al., Scalable molecular dynamics with NAMD. J Comput Chem, 2005. 26(16): p. 1781-802.

104. Hess, B., et al., GROMACS 4: Algorithms for highly efficient, load-balanced, and scalable molecular simulation. Journal of Chemical Theory and Computation, 2008. 4(3): p. 435-447.

105. Groenhof, G., Introduction to QM/MM simulations. Methods Mol Biol, 2013. 924: p. 43-66. 
106. van Duin, A.C.T., et al., ReaxFF: A reactive force field for hydrocarbons. Journal of Physical Chemistry A, 2001. 105(41): p. 9396-9409.

107. Ponder, J.W. and D.A. Case, Force fields for protein simulations. Adv Protein Chem, 2003. 66: p. 27-85.

108. Oostenbrink, C., et al., A biomolecular force field based on the free enthalpy of hydration and solvation: the GROMOS force-field parameter sets $53 A 5$ and 53A6. J Comput Chem, 2004. 25(13): p. 1656-76.

109. Siu, S.W., K. Pluhackova, and R.A. Bockmann, Optimization of the OPLS-AA Force Field for Long Hydrocarbons. J Chem Theory Comput, 2012. 8(4): p. 1459-70.

110. Jorgensen, W.L. and J. Tirado-Rives, The OPLS [optimized potentials for liquid simulations] potential functions for proteins, energy minimizations for crystals of cyclic peptides and crambin. J Am Chem Soc, 1988. 110(6): p. 1657-66.

111. Tom Darden, D.Y., Lee Pedersen, Particle mesh Ewald: An $N \cdot \log (N)$ method for Ewald sums in large systems J. Chem. Phys., 1993. 98.

112. H. J. C. Berendsen, J.P.M.P., W. F. van Gunsteren and J. Hermans, Intermolecular Forces. Intermolecular Forces (Reidel, Dordrecht, 1981) p331., 1981.

113. Jorgensen, W.L., et al., Comparison of Simple Potential Functions for Simulating Liquid Water. Journal of Chemical Physics, 1983. 79(2): p. 926-935.

114. Madura, W.L.J.a.J.D., Temperature and size dependence for monte carlo simulations of TIP4P water. Molecular Physics, 1985. 56 p. 1381-1392.

115. Mahoney, M.W. and W.L. Jorgensen, A five-site model for liquid water and the reproduction of the density anomaly by rigid, nonpolarizable potential functions. Journal of Chemical Physics, 2000. 112(20): p. 8910-8922.

116. Kusalik, P.G. and I.M. Svishchev, The spatial structure in liquid water. Science, 1994. 265(5176): p. 1219-21. 
117. Abascal, J.L. and C. Vega, A general purpose model for the condensed phases of water: TIP4P/2005. J Chem Phys, 2005. 123(23): p. 234505.

118. Thomas J.Dick, J.D.M., A Review of the TIP4P, TIP4P-Ew, TIP5P, and TIP5P-E Water Models. Annual Reports in Computational Chemistry, 2005. 1: p. 59-74.

119. Hukushima, K. and K. Nemoto, Exchange Monte Carlo method and application to spin glass simulations. Journal of the Physical Society of Japan, 1996. 65(6): p. 16041608.

120. Shirakura, T. and F. Matsubara, Reexamination of the SG transition in the twodimensional +/-J Ising model. Journal of the Physical Society of Japan, 1996. 65(10): p. $3138-3141$.

121. Sugita, Y. and Y. Okamoto, Replica-exchange molecular dynamics method for protein folding. Chemical Physics Letters, 1999. 314(1-2): p. 141-151.

122. Joung, I.S. and T.E. Cheatham, Determination of alkali and halide monovalent ion parameters for use in explicitly solvated biomolecular simulations. Journal of Physical Chemistry B, 2008. 112(30): p. 9020-9041.

123. Baaden, M., et al., M(3+) lanthanide cation solvation by acetonitrile: The role of cation size, counterions, and polarization effects investigated by molecular dynamics and quantum mechanical simulations. Journal of Physical Chemistry A, 2000. 104(32): p. 7659-7671.

124. Lindorff-Larsen, K., et al., Improved side-chain torsion potentials for the Amber ff99SB protein force field. Proteins-Structure Function and Bioinformatics, 2010. 78(8): p. 1950-1958.

125. Bussi, G., D. Donadio, and M. Parrinello, Canonical sampling through velocity rescaling. Journal of Chemical Physics, 2007. 126(1). 
126. Parrinello, M. and A. Rahman, Polymorphic Transitions in Single-Crystals - a New Molecular-Dynamics Method. Journal of Applied Physics, 1981. 52(12): p. 71827190 .

127. Hess, B., et al., LINCS: A linear constraint solver for molecular simulations. Journal of Computational Chemistry, 1997. 18(12): p. 1463-1472.

128. Patriksson, A. and D. van der Spoel, A temperature predictor for parallel tempering simulations. Phys Chem Chem Phys, 2008. 10(15): p. 2073-7.

129. Kubo, R., Statistical Mechanics. 2004, Amsterdam, The Netherlands: Elsevier.

130. Eisenhaber, F., et al., The Double Cubic Lattice Method - Efficient Approaches to Numerical-Integration of Surface-Area and Volume and to Dot Surface Contouring of Molecular Assemblies. Journal of Computational Chemistry, 1995. 16(3): p. 273-284.

131. Mehrotra, P.K. and D.L. Beveridge, Structural-Analysis of Molecular Solutions Based on Quasi-Component Distribution-Functions - Application to [H2co]Aq at 25Degrees-C. Journal of the American Chemical Society, 1980. 102(13): p. 4287-4294.

132. Mezei, M. and D.L. Beveridge, Structural Chemistry of Biomolecular Hydration Via Computer-Simulation - the Proximity Criterion. Methods in Enzymology, 1986. 127: p. 21-47.

133. Makarov, V.A., B.K. Andrews, and B.M. Pettitt, Reconstructing the protein-water interface. Biopolymers, 1998. 45(7): p. 469-478.

134. Friedman, R., E. Nachliel, and M. Gutman, Molecular dynamics of a protein surface: Ion-residues interactions. Biophysical Journal, 2005. 89(2): p. 768-781.

135. Iwahara, J., A. Esadze, and L. Zandarashvili, Physicochemical Properties of Ion Pairs of Biological Macromolecules. Biomolecules, 2015. 5(4): p. 2435-2463.

136. Géza Groma, F.S., Zoltán Násztor, Áron Sipos, János Horváth, Rita Nagypál, András Dér, Zsuzsanna Heiner, Thomas Rowland, Jérémie Leonard, S. Haacke, 
Conformational states of coenzymes FAD and NADH monitored by ultrafast spectroscopy. Biochimica et Biophysica Acta (BBA) - Bioenergetics, 2018.

137. Horinek, D., et al., Specific ion adsorption at the air/water interface: The role of hydrophobic solvation. Chemical Physics Letters, 2009. 479(4-6): p. 173-183.

138. Cox, W.W., J., The Viscosity of Strong Electrolytes Measured by a Differential Method. Proc. R. Soc. London, 1934. 145: p. 475-488.

139. Omta, A.W., et al., Negligible effect of ions on the hydrogen-bond structure in liquid water. Science, 2003. 301(5631): p. 347-349.

140. Stirnemann, G., et al., Mechanisms of Acceleration and Retardation of Water Dynamics by Ions. Journal of the American Chemical Society, 2013. 135(32): p. 11824-11831.

141. Aoki, K., K. Shiraki, and T. Hattori, Observation of salt effects on hydration water of lysozyme in aqueous solution using terahertz time-domain spectroscopy. Applied Physics Letters, 2013. 103(17).

142. Perticaroli, S., et al., Broadband Depolarized Light Scattering Study of Diluted Protein Aqueous Solutions. Journal of Physical Chemistry B, 2010. 114(24): p. 82628269.

143. Sterpone, F., G. Stirnemann, and D. Laage, Magnitude and molecular origin of water slowdown next to a protein. J Am Chem Soc, 2012. 134(9): p. 4116-9.

144. Jamadagni, S.N., R. Godawat, and S. Garde, Hydrophobicity of Proteins and Interfaces: Insights from Density Fluctuations. Annual Review of Chemical and Biomolecular Engineering, Vol 2, 2011. 2: p. 147-171.

145. Godawat, R., S.N. Jamadagni, and S. Garde, Characterizing hydrophobicity of interfaces by using cavity formation, solute binding, and water correlations. Proceedings of the National Academy of Sciences of the United States of America, 2009. 106(36): p. 15119-15124. 
146. dos Santos, A.P. and Y. Levin, Surface and interfacial tensions of Hofmeister electrolytes. Faraday Discussions, 2013. 160: p. 75-87.

147. Zhao, L., W.Z. Li, and P. Tian, Reconciling Mediating and Slaving Roles of Water in Protein Conformational Dynamics. Plos One, 2013. 8(4).

148. Kou, R., et al., Interactions between Polyelectrolyte Brushes and Hofmeister Ions: Chaotropes versus Kosmotropes. Langmuir, 2015. 31(38): p. 10461-10468. 


\section{Az értekezésben felhasznált saját publikációk:}

P1. Bogar, F., et al., On the Hofmeister Effect: Fluctuations at the Protein Water Interface and the Surface Tension. Journal of Physical Chemistry B, 2014. 118(29): p. 84968504.

P2. Nasztor, Z., F. Bogar, and A. Der, The interfacial tension concept, as revealed by fluctuations. Current Opinion in Colloid \& Interface Science, 2016. 23: p. 29-40.

P3. Nasztor, Z., A. Der, and F. Bogar, Ion-induced alterations of the local hydration environment elucidate Hofmeister effect in a simple classical model of Trp-cage miniprotein. Journal of Molecular Modeling, 2017. 23(10).

\section{Egyéb saját publikációk:}

P4. Horvath, J., et al., Characterizing the Structural and Folding Properties of LongSequence Hypomurocin B Peptides and Their Analogs. Biopolymers, 2016. 106(5): p. 645-657.

P5. Bogar, F., et al., Opposite effect of $\mathrm{Ca} 2+/ \mathrm{Mg} 2+$ ions on the aggregation of native and precursor-derived A beta(42). Structural Chemistry, 2015. 26(5-6): p. 1389-1403.

P6. Nasztor, Z., J. Horvath, and B. Leitgeb, Studying the Structural and Folding Features of Long-Sequence Trichobrachin Peptides. Chemistry \& Biodiversity, 2015. 12(9): p. $1365-1377$.

P7. Nasztor, Z., J. Horvath, and B. Leitgeb, In silico conformational analysis of the shortsequence hypomurocin a peptides. Int J Pept, 2015. 2015: p. 281065.

P8. Nasztor, Z., J. Horvath, and B. Leitgeb, Structural Characterization of the Short Peptaibols Trichobrachins by Molecular-Dynamics Methods. Chemistry \& Biodiversity, 2013. 10(5): p. 876-886. 
RDF-eket használtunk az egyes ionok hidratációs burkait jellemző távolságok meghatározására. A számolások során a vízmolekulák oxigén atomjainak térbeli eloszlását vizsgáltuk külön-külön minden ion körül. A tiszta vizes esetben a számolást az összes víz oxigén atomra végeztük el. A több atomból álló perklorát esetében az RDF-et a központi $\mathrm{Cl}$ atomra való tekintettel származtattuk. A kapott RDF-eket az 1F. ábra mutatja. A F és a $\mathrm{Na}^{+}$ ionok esetén jól definiált első- és második hidratációs burkokat lehet azonosítani. Ezzel ellentétben a perklorát ionoknak kevésbé van affinitásuk hidratációs burok kialakítására, a víz molekulákkal történő kölcsönhatása még a tiszta vizes rendszerrel összevetve is korlátozottnak mutatkozik. Az hidratációs burkok határait az RDF-ek minimum helyei segítségével határoztuk meg. A minimum és maximum helyeket az 1F. táblázat tartalmazza. A vizsgált ionok különböző méretűek és töltésük, továbbá a perklorát több atomból áll, ennek a következménye, hogy az egyes RDF-ek más-más távolságtól mutatnak nem nulla értékeket.

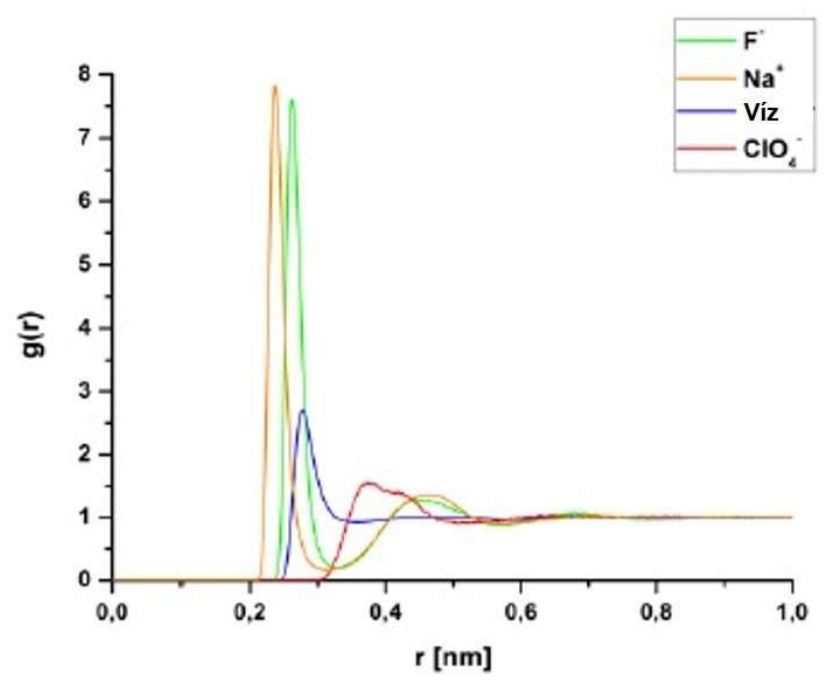

1F. ábra $A$ víz oxigén atomok RDF-je a vizsgált ionok körül és a víz oxigén atomok RDF-je egymás körül.

\begin{tabular}{cccccc}
\hline \hline & $\mathbf{I}$ & 1. maximum & 1. minimum & 2. maximum & 2.minimum \\
\hline \hline $\mathrm{F}^{-}$ & $\mathbf{I}$ & 0,262 & 0,324 & 0,444 & 0,568 \\
$\mathrm{Na}^{+}$ & $\mathbf{I}$ & 0,236 & 0,314 & 0,458 & 0,564 \\
Víz-Víz $^{-}$ & $\mathbf{I}$ & 0,278 & 0,358 & - & - \\
$\mathrm{ClO}_{4}^{-}$ & $\mathbf{I}$ & 0,374 & 0,502 & - & - \\
\hline \hline
\end{tabular}

1F. táblázat A víz oxigén atom RDF-ek minimum és maximum helyei nm-ben az ionokat tartalmazó és a tiszta vizes rendszerek esetében. 
A DDCI görbéket a tc5b minifehérje hiányában is meghatároztuk a vizsgált ionokra. A 2F. ábrán látható a kozmotróp $\mathrm{F}^{-}$és a kaotróp $\mathrm{ClO}_{4}{ }^{-}$ionok és a $\mathrm{Na}^{+}$ionok között létrejövő $\mathrm{CP}, \mathrm{SSP}$ és 2SP típusú kölcsönhatások magvalósulást jellemzö görbék. A szimulációs rendszer csak a $\mathrm{NaF}_{\text {és }} \mathrm{NaClO}_{4}$ sókat tartalmazta 1 mólos koncentrációban, minden más releváns MD beállítás változatlan maradt. A CP típusú kölcsönhatás sem a $\mathrm{NaF}$, sem a $\mathrm{NaClO}_{4}$ sók esetén sem a leginkább preferált, hanem SSIP, vagy 2SIP típus a jellemzőbb. Továbbá a méretbeli hasonlóság és az ellentétes töltés ellenére a CP típusú kölcsönhatás kevésbé jellemző a NaF sóra, mint a $\mathrm{NaClO}_{4}$ sóra.

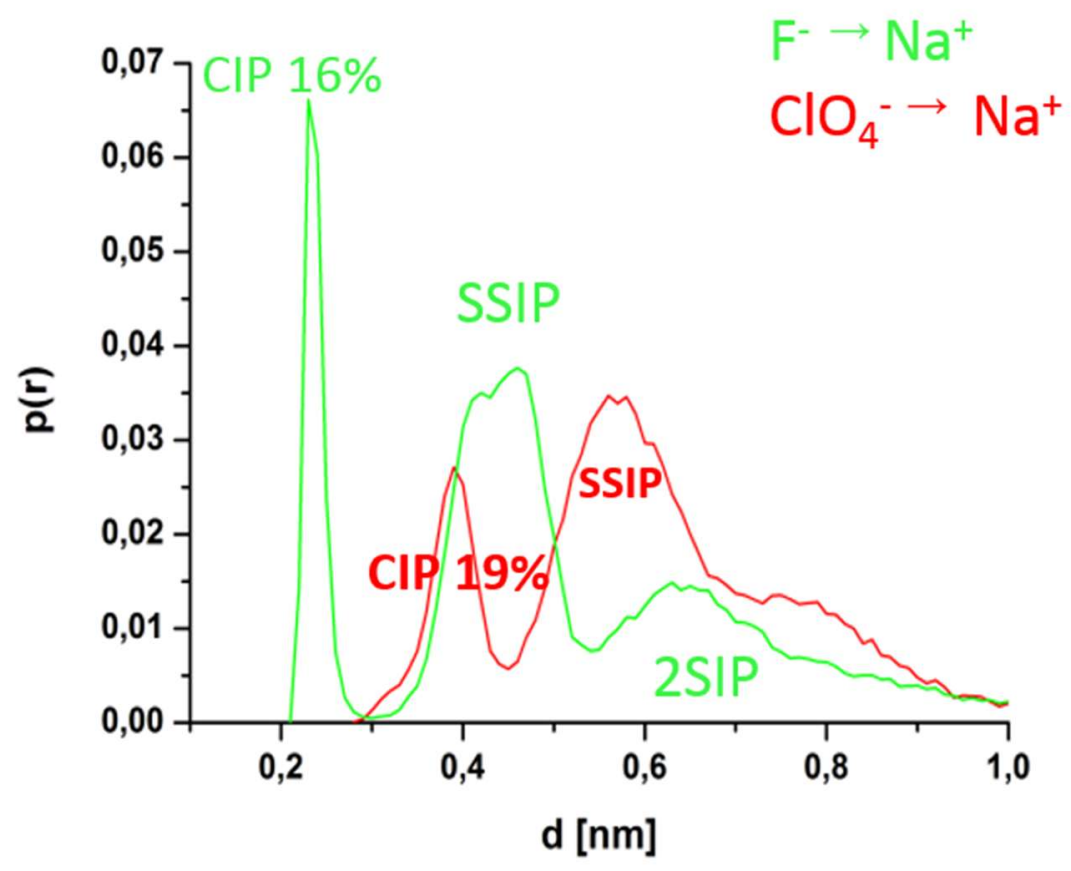

2F. ábra a $\mathrm{F}^{-}$és a $\mathrm{ClO}_{4}{ }^{-}$ionok $\mathrm{Na}^{+}$ionnal történő párképzési hajlandóságát jellemző DDCI görbék és a közvetlen kölcsönhatás kialakulásának valószínüsége \%-ban kifejezve. 